SB

.1453 


$$
\text { ช }
$$




. 



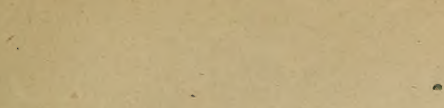

(1)

-

. 



\section{A MANUAL OF}

\section{FARM GRASSES}

\section{A. S. HITCHCOCK}

Systematic Agrostologist, United States Department of Agriculture, Washington, D. C.; formerly Professor of Botany in the

Kansas State Agricultural College

\section{PUBLISHED BY THE AUTHOR}

WASHINGTON, D. C. 


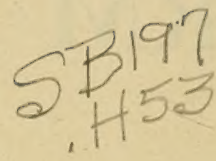

Copyright, I92 I

By A, S. HIтснсоск

JAN 241921

(2) Cl. 4605502 


\section{PREFACE}

The forage grasses are of great interest to the farmer, and the grass crop is in the aggregate one of the most important grown upon the farm. The grasses and the clovers, including alfalfa, are the basis of the stock industry. The call for authentic information upon the forage grasses has been extended and insistent. In the present volume an attempt has been made to supply to the farmer, ranchman, and stockman, and also to the agriculturist and experiment station worker, a compendium of information on the grasses used for forage. The book is intended primarily to give information by which the cultivated grasses may be identified, and by which one may determine their range, adaptibility, and uses. Secondary to this is information on the culture of the grasses.

To aid in the identification of the grasses the descriptions are supplemented by drawings from nature by Mrs. Mary Wright Gill, the well-known agrostological artist.

In addition to the information on the forage grasses there has been added a brief account of grasses used for other purposes, such as lawns and ornamentals.

\section{A. S. Hitch COCK}

I 867 PARK ROAD,

WAShington, D. C.,

October I, I920 



\section{TABLE OF CONTENTS}

\section{CHAPTER I}

INTRODUCTION . . . . . . . . . I $\ldots \ldots \ldots$

\section{CHAPTER II}

Statistics of the Grass Crop ......... 4 4 4

The value, acreage, and distribution of grass crops in the United States, based upon the figures of the Thirteenth Census.

\section{CHAPTER III}

General Remarks on Forage Grasses.... Io Io-29

Classification of Forage Plants . . . . . . . . . . 10-12

Grasses, Io-Legumes, II - Other forage plants, I2.

Forage Crop Areas............... I2-I5

Cool Humid Region, I2-Warm Humid Region, I3-Semiarid Region, I4-Arid Region, I5-Region of winter rains, 15 .

Uses of Forage Plants............ I6-27

Pastures, I6-Permanent pasture, I8Meadows, 22-Wild hay, 22-Grain hay, 23-Legume hay, 23-Coarse hay or fodder, 24-Millet, 25-Ordinary meadow hay, 26Soiling, 26-Silage, 27. 
Nomenclature of Grasses. . . . . . . . . ‘ 27-29

\section{CHAPTER IV}

PAGES

Culture of Grasses. . . . . . . . . . . . . $30-43$

General Principles, 30-Preparation of the soil, 30-Sowing the seed, 3I-Care of pastures, 32-Care of meadows, 34-Making hay, 34-Grass in rotation, 36-Grass seed, 37.

\section{CHAPTER V}

The Structure of Grasses ...............
Roots and rootstocks, 45 -Stem and leaves, 46 -Flowers and seed, 48.

\section{CHAPTER VI}

The Three Leading Forage Grasses. . . . 5 53-76 Timothy . . . . . . . . . . . . . . . . 53-57

Timothy as a meadow grass, 55-Description, 57 .

Bluegras $5^{8-70}$

Bluegrass for pasture, 59-Bluegrass for lawns, 60-Making a bluegrass lawn, 6ILawn weeds, 65-Bluegrass seed, 66-Bluegrass as a weed, 67-Description, 67.

Bermuda Grass. . . . . . . . . . . . . . . 70 70-76

Bermuda as a pasture grass, $7 \mathbf{I}$-Bermuda for lawns, 72-Methods of eradication, 73Description, 74 . 


\section{CHAPTER VII}

Other Important ForaGe Grasses.........

Redtop, 77-Orchard grass, 80-Meadow fescue, 83-Johnson grass, 85 -Brome grass, 89.

\section{CHAPTER VIII}

Grasses of Minor Importanç . . . . . . . 92-I I 8

Rhode Island bent and carpet bent, 92-

Rye grasses, 95-Tall oat grass, 99-Canada bluegrass, I00-Sweet vernal grass, I02Velvet grass, I03-St. Augustine grass, I04 - Carpet grass, I05-Rescue grass, I07Guinea grass, I07-Para grass, 107-The fescue grasses, I09-Rhodes grass, I I INatal grass, I I2-Slender wheat grass, II3 -A few other grasses, II4.

\section{CHAPTER IX}

Annual Forage Crops . . . . . . . . . . . . II9-134

Common millet, I I9-Proso millet, I22Japanese barnyard millet, I24-Pearl millet, I26-The sorghums, I26-Sudan grass, I30 -Teosinte, I3I-Corn, I32-The small grains, I33-Chess or cheat, I33.

\section{CHAPTER X}

Native Forage Grasses. . . . . . . . . . I35-I5I

Plains, I36-Valleys, I39-Deserts, I42Humid forests, I44-Mountain meadows, 
I45-Wild hay, I46-Cultivated native grasses 147 .

\section{CHAPTER XI}

Other Economic Grasses........... I5 I-I 58

Lawn grasses, I5I-Ornamentals, I53-

Sand binders, I56-Fiber grasses, I57Sugar-producing grasses, I 57 .

\section{CHAPTER XII}

WeEdy Grasses. . . . . . . . . . . . . I59-167

Eradication of quack grass, I60-Annual weeds, I62-Weeds upon the range, I66. 


\section{LIST OF ILLUSTRATIONS}

FIG.

I. Magnifying glass for examining seeds . . . . . . 39

2. Seeds of some common grasses........... 40

3. Spikelet of wheat. . . . . . . . . . . . . 49

4. Timothy ................... 57

5. Kentucky Bluegrass................ 68

6. Bermuda Grass . . . . . . . . . . . . . . . . 74

7. Redtop . . . . . . . . . . . . 78

8. Orchard Grass . ................... 82

9. Meadow Fescue . . . . . . . . . . . . . . 84

I0. Johnson Grass. . . . . . . . . . . . . . 88

I I. Brome Grass . . . . . . . . . . . . . . . . 90

I2. Rhode Island Bent . . . . . . . . . . . . . 94

13. Italian Rye Grass . . . . . . . . . . . . . . . . 97

I4. Perennial Rye Grass . . . . . . . . . . . . . . 98

I5. Tall Oat Grass . . . . . . . . . . . . . . Ioo

I6. Canada Bluegrass................... Iо I

I7. Sweet Vernal Grass. . . . . . . . . . . . . I02

I8. Velvet Grass . . . . . . . . . . . . . . . . I03

19. St. Augustine Grass . . . . . . . . . . . . . I04

20. Carpet Grass . . . . . . . . . . . . . . . I06

2 I. Rescue Grass . . . . . . . . . . . . . . . . . . . I08

22. Sheep's Fescue . . . . . . . . . . . . . I I

23. Rhodes Grass... . . . . . . . . . . . . . . II 2

24. Natal Grass. . . . . . . . . . . . . . . . II

25. Paspalum dilatatum . . . . . . . . . . I I 5

26. German millet................ I2 I 
FIG. Pages

27. Hungarian Grass................. 122

28. Proso Millet. . . . . . . . . . . . . . I 123

29. Japanese Barnyard Millet.............. I25

30. Pearl Millet.................... 126

31. Buffalo Grass.................... . 136

32. Grama Grass. . . . . . . . . . . . . . I I37

33. Curly Mesquite ................ I38

34. Big Bluestem ................... I4I

35. Quack Grass . . . . . . . . . . . . . . . . I60

36. Crab grass .................. 163 


\section{CHAPTER I}

\section{INTRODUCTION}

IN all parts of the United States, forage plants are an important element in all kinds of farming that involve live stock. Even on farms devoted to special crops such as vegetables or fruits the use of farm animals may bring the question of forage into the foreground. For these reasons nearly all farmers and stockmen are interested in grasses. In those regions that have been long settled, farm practice has included the use of certain grasses, the kind depending upon the region. The farmer is familiar with these grasses and understands their use and may need no further information upon these. It often happens, however, that the farmer wishes to try other kinds of grasses of which he has heard but with which he is not familiar. He may have read about them in farm journals or he may have seen them advertised in seed catalogues. Interested dealers or growers may, in their enthusiasm or greed, honestly or dishonestly recommend them in flamboyant language or with exaggerated praise.

It is hoped that the present work will give information that will enable the farmer to form a correct judgement as to the value of particular kinds of grasses for his conditions. Some kinds of grass are well suited to one set of conditions but entirely unsuited to others and no grass is suited to all the various conditions found throughout 
the country. The reader who wishes to try new or unfamiliar kinds of grass should study the chapter on crop areas and then read what is said about this grass under the chapter or paragraph devoted to it. All kinds of grasses known to haveany value anywhere in the United States, are here described and also several kinds that are practically valueless anywhere, but which have been referred to in agricultural works or have been offered for sale by seedsmen.

Sometimes an old grass is advertised under a new name and thus exploited. Many are familiar with the frequent thrusting into notoriety of new kinds of wheat such as mummy wheat, Alaska wheat, and Egyptian wheat, with marvelous tales of high yield, but which upon examination by experts prove to be old varieties which have no especially good qualities to recommend them. Billion dollar grass was exploited at one time in this way. It is well to be on guard against deception or honest but unwarranted enthusiasm.

The U. S. Department of Agriculture and the State Experiment Stations have sought out grasses from all over the world and carefully tested them, and the possibilities of all kinds are pretty well known. The probability of some new kind coming suddenly into use is very slight. Hence, exploitation of a supposedly new kind of grass by interested persons should be looked upon with suspicion and the claims made for it subjected to the keenest scrutiny.

The farmer should endeavor to grow the grass best suited to his conditions. Even on the same farm the conditions may vary so much that one kind of grass may 
succeed in one part but fail in another part, while in this second place another sort may succeed. Every grass has its good points and its bad points. It should be the endeavor of the farmer to learn these points and it is hoped that this book may aid him in the attempt. 


\section{CHAPTER II}

\section{STATISTICS OF THE GRASS CROP}

THE value of the grass crop of the United States is much greater than is generally supposed. A large proportion is fed upon the farm and thus does not directly swell the cash income. The figures given below are all taken from the report of the thirteenth census. The total value of all farm crops produced in the United States in 1909 was $\$ 5,487, \mathrm{I} 6 \mathrm{I}$, 000. Of this amount the cereals take the lead with a total value of $\$ 2,665,539,7 \mathrm{I} 4$. The values of the cotton crop and of the hay and forage crop are about equal, being respectively $\$ 824,696,287$ and $\$ 824,004,887$, and hence divide honors for second and third place. The other crops are much less. It must be remembered that the statistics do not include the value

\section{TABLE I}

Production (Tons) of Hay and Forage of the Twenty LEAding States IN 1909

I. Iowa . . . . . . 7,823, I 8 I

2. New York ..... 7,055,429

3. Minnesota .....6,036,747

4. Kansas...... 5, 5,936,997

5. Nebraska ..... 5, 5,76,475

6. IVisconsin .... . 5,002,644

7. Ohio .......4.4,521,409

8. Illinois .......4, $4,354,466$

9. California ....... 4,327, I 30

I0, Missouri..., , , , 4,091,342
II. Pennsylvania....3,677,307

I2. South Dakota . . .3,651,024

13. Michigan ......3,632,939

14. North Dakota....3, 010,40I

I5. Indiana . . . . . 2,880, I04

I6. Colorado . . . . . .2,241,566

I7. Montana . . . . . I, 692,656

r8. Oregon . . . . . . I I,587,796

19. Idaho......... I,584,365

20. Vermont........ I,502,730 
of pasture and range which, if added, would place the value of forage far above that of cotton. The total acreage of grassland as reported by the census was $72,280,776$ and the total production $97,454,000$ tons, the average yield thus being I.35 tons per acre. The preceding table shows the production of hay and forage for the 20 leading states.

Six other states had a production exceeding $\mathrm{I}, 000,000$ tons.

The value of the hay and forage crop varies according to the kind, consequently in the table showing this the sequence of states is somewhat altered.

\section{TABLE II}

Value in Dollars of Hay and Forage of the Twenty Leading States in 1909

I. New York .... $\$ 77,360,645$ II. Nebraska . .....\$3I,729,69I

2. Iowa ....... 59,360,225 I2. Minnesota.... 26,724,80I

3. Pennsylvania ... 45,623,573 I3. Indiana ..... 24,883,46I

4. Ohio........ 42,357,364 I4. Colorado ..... I7,282,276

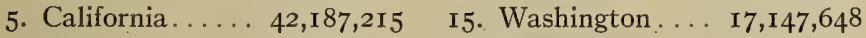

6. Wisconsin .... 40,866,396 I6. Vermont....... I6,335,530

7. Illinois ....... 40,560,220 I7. South Dakota .. I5,243,664

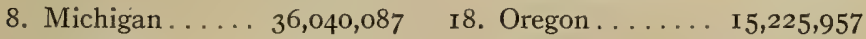

9. Missouri...... 33,845,094 I9. Maine........ I5, I I5,82 I

Io. Kansas . . . . . 32,033,954

20. Texas....... $12,824,433$

Seven other states produced a crop valued at more than $\$ 10,000,000$.

The kind of forage produced is of great interest but the Census Report does not classify very closely. in this respect.

Table III gives the results so far as the classification extends. 


\section{TABLE III}

Acreage, Production, and Value of Hay and Forage FOR I9OI BY ClASSES

\begin{tabular}{|c|c|c|c|}
\hline & Acres & $\begin{array}{l}\text { Production } \\
\text { (Tons) }\end{array}$ & Value (Dollars) \\
\hline Timothy alone .......... & I4 $4,686,393$ & $17,985,420$ & $\$ \mathrm{I} 88,082,895$ \\
\hline Timothy and Clover mixed & I $9,542,382$ & $24,748,555$ & $257,280,330$ \\
\hline Clover alone . . . . . . . . . . & $2,443,263$ & $3,158,324$ & $29,334,356$ \\
\hline Alfalfa............... & $4,707,146$ & I I $, 859,88 \mathrm{I}$ & $93, \mathrm{IO} 3,998$ \\
\hline Millet or Hungarian grass & $\mathrm{I}, \mathrm{I} 17,769$ & $\mathrm{I}, 546,533$ & I I, I 45,226 \\
\hline $\begin{array}{l}\text { Other tame or cultivated } \\
\text { grasses }\end{array}$ & 42,8057 & 466772 & - \\
\hline Wild, salt, or prairie grasses. & $\begin{array}{r}4,210,957 \\
17,186,522\end{array}$ & $\begin{array}{r}4,100,772 \\
\mathbf{1} 8,383,574\end{array}$ & $91,026,169$ \\
\hline Grains cut green ......... & $4,324,878$ & $5,367,292$ & $6 \mathrm{I}, 686, \mathrm{I} 3 \mathrm{I}$ \\
\hline Coarse forage ........... & $4,034,432$ & $9,982,305$ & $46,753,262$ \\
\hline
\end{tabular}

The taking of a census is an enormous task. All farmers are aware of the number and variety of questions asked by the enumerators. At each census a greater variety of statistics is gathered than at the preceding, and we may hope that in future censuses a still further classification of the forage crops may be possible. The instructions issued to the census clerks contain the following in regard to hay and forage crops:

(a) Tabulate as "clover alone" all crops reported after that designation, as well as all reported as "alsike," "red clover," "crimson clover;" also other clovers unmixed with other grasses. The same crops reported as mixed with timothy or herd's grass should be tabulated as "timothy and clover mixed." When reported as mixed with grasses other than timothy or herd's-grass, they should be tabulated as "other tame or cultivated grasses."

(b) Tabulate as "other tame or cultivated grasses" all crops reported after that designation, as well as all reported as "redtop," "June-grass," "orchard-grass," "blue-grass," and "Johnson-grass;" also all combinations of these grasses with any of the clover crops mentioned in paragraph $a$, preceding, or with timothy. 
(c) Tabulate as "wild, salt, or prairie grasses" all crops reported after that designation, as well as all reported as " marsh-grass," "swamp-grass," "slough-grass," "bluestem," "daisies," and "butter-cups."

(d) Tabulate as "grains cut green" all crops reported after that designation without specific names, or with the name "oats," "wheat," "barley," "rye," "peas," "cowpeas," "soybeans," "velvetbeans," or "vetches." Keep a memorandum of the names of all crops reported with specific names and tabulated as "grains cut green."

(e) Tabulate as "coarse forage" all crops reported after that designation without specific names, or with the name "corn," "sweet corn," "cane," "sorghum," "Kafir corn," "Jerusalem corn," "milo maize," or kindred crops.

It will be seen from this that the classification is only approximate. The following tables show the relative importance of the different kinds of forage in the different regions of the United States.

\section{TABLE IV}

The Production (Tons) of Hay and Forage for i909, by the Ten Leading States, of Each Kind of Forage

\section{Timothy}
I. Ohio ........2, 2,348,660
6. Pennsylvania .... I, 200,073
2. Iowa ......... 1,952,956
7. New York...... I, I59,083
3. Illinois . . . . . . I,947,572
8. Wisconsin ...... I, II, 446
4. Indiana ....... I, 442,2 I 8
9. Minnesota ...... I, IOI, 510
5. Missouri........ I,334,556
Io. Michigan ....... 929,165

Timothy and clover mixed

I. Iowa . . . . . . 3,732,186

2. New York ..... 3,2 I 5,02 I

3. Wisconsin . . . . 2, 2,477,3 I I

4. Michigan ...... I, $99 \mathrm{I}, 6 \mathbf{I} 8$

5. Pennsylvania.... I, 830,852
6. Missouri ....... I, 630,2II

7. Minnesota . . . . . I I, 433,075

8. Ohio ......... I, 346,347

9. Illinois ........ I, I23,254

Io. Vermont...... 628,098 


\section{Clover alone}

I. Illinois ...... $539,790 \quad$ 6. Tennessee ..... 201,926

2. Indiana ....... 314,8 I8 7. Iowa ......... I95,579

3. Missouri....... 309,209 8. Wisconsin ..... I93,786

4. Ohio... . . . . . 239,492 9. New York...... I I 4,864

5. Michigan....... 216,862 I0. Minnesota...... I06,334

\section{Alfalfa .}

r. Kansas. . . . . . . I,998,689

6. Utah . . . . . . 791,355

2. California....... I,639,707

7. Montana ...... 599,747

3. Nebraska ....... I,522,1,36

8. Wyoming ...... 39 397,669

4. Colorado ........ I,265,9 I 5

9. Oregon ........ 375,445

5. Idaho......... 964,529

Io. Washington ..... 357,595

Millet or Hungarian grass

I. Kansas. . . . . . 29 290,66I

6. Tennessee ..... 76,3 II

2. Nebraska ....... I I60,684

7. Oklahoma ...... 75,59I

3. North Dakota... I I 49,429

8. South Dakota.... 65,844

4. Missouri........ I4I,626

9. Iowa ... . . . . . . 54,346

5. Texas........ 95,352

ro. Minnesota...... 50,383

Other tame or cultivated grasses

r. New York...... 4r 4,479

6. Connecticut..... I 59,365

2. Maine........ 258,789

7. Massachusetts.... I 150,723

3. Tennessee ...... 218,482

8. Kentucky........ I39,382

4. Minnesota . ..... I 88,37 I

9. Texas......... I $138,75^{8}$

5. Vermont....... I60,0I4

Io. New Hampshire .. I3I,62 I

Wild, salt, or prairie grasses
I. Nebraska . . . . 3,097,822
6. Iowa .......... I, I78,000
2. South Dakota... 2,798,263
7. Oklahoma ...... 607,120
3. Minnesota..... 2,7 I4, I 2 I
8. Montana . . . . . . . 589,860
4. North Dakota....2,372,6I8
9. Wisconsin ..... 497,622
5. Kansas........ 1,737,632
Io. Colorado . . . . . 3 368,408

Grains cut green
I. California ......2,019,526
6. South Carolina ... I33,996
2. Oregon ......... 509,030
7. Georgia ........ I28,929
3. Viashington ..... 499,955
8. Louisiana ....... I 27, I 26
4. Idaho ......... I40,098
9. North Carolina ... I I 8,687
5. Tennessee ...... I 36,674
Io. Illinois . . . . . . 99, 9928 
Coarse forage

I. New York. . . . . I,876,795

2. Kansas . . . . . . . I,263,23I

3. Texas........ 688,274

4. Wisconsin ...... 571,44I

5. Iowa $\ldots \ldots \ldots \ldots$ 5 5 I0, 184
6. Vermont....... 452,46I

7. Ohio......... 443,512

8. Pennsylvania .... 422,925

9. Minnesota...... 40 4,6I4

Io. Michigan ...... 379,279

From Table IV it is seen that timothy and clover are the most important cultivated forage crops. These are grown mainly in the "humid region," usually known as the timothy region. Next in importance is the wild hay crop which comes mostly from the eastern portion of the Great Plains, the chief constituent being prairie hay.

The alfalfa crop comes from the western states where irrigation is practiced, though it is worthy of note that in the leading state, Kansas, much of the crop is grown without irrigation. Millet comes mostly from the eastern belt of the Great Plains. Under the head of "other tame or cultivated grasses," the most important elements are redtop, grown in the northeastern states, Johnson grass, in Texas and some other southern states, and orchard grass, in Tennessee and Kentucky. Under the head of "grains cut green," are two important elements, grain hay on the Pacific Coast, and the cowpea in the Southern States. The Canada field pea is an important crop along our northern border. Under "coarse forage" are included corn and sorghum cut for forage. The tables should be studied in connection with the chapter on Forage Crop Areas. 


\section{CHAPTER III}

\section{GENERAL REMARKS ON FORAGE GRASSES}

IN order to understand the relation between the different kinds of grasses grown for forage and the conditions suited to their culture it is necessary to keep in mind the uses to which the grass crop is put and the conditions which must be met by the crop in different parts of the United States. The classification of the forage crops will first be set forth and then the classification of the crop areas.

\section{CLASSIFICATION OF FORAGE PLANTS}

Forage plants are those whose foliage or green portions furnish food for stock. The plants cultivated for forage belong, for the most part, to two natural groups or families, the grasses (Gramineae) and the legumes (Leguminosae). A few forage plants belong to other groups.

\section{GRASSES}

The grass family comprises a large and important group of plants, found growing in all parts of the world where any vegetation is possible, from sea level to the limits of perpetual snow in the highest mountains, from the tropics to the north and south polar regions, in the humid rain-forest, the vast steppes and arid plains, and the sandy wastes and rocky cliffs of all altitudes and latitudes. Grasses are the predominating vegetation on 
all open land known under the general name of plains, an example of which is the area called the Great Plains of North America. Other areas of this kind are the steppes of Russia, and the llanos and pampas of South America. Grazing animals feed upon many kinds of plants but of these the grasses are by far the most important.

The grasses are distinguished by having narrow leaves arranged in two rows or ranks, by having small greenish flowers usually in heads or panicles, and by the fruit or seed which is a grain like the kernel of wheat or seed of timothy. To the grass family belong the common meadow and pasture grasses, such as timothy, redtop, and bluegrass, the cereals, such as wheat and rice, and also certain larger plants such as, corn, sorghum, and sugar cane. The sedges and rushes of ten have grass-like leaves but are distinguished from the grass family by the structure of the flowers and fruit. The sedges that most closely resemble grasses in general appearance can be distinguished by their 3 -sided stems and 3 -ranked leaves. In general the sedges inhabit marshes and other wet places and are of little value as forage.

\section{LEGUMES}

The legumes are plants bearing pods and peculiarly shaped flowers like those of the pea. They usually have compound leaves. Well known plants of the legume family are the clovers, alfalfa, peas, beans, and vetches. The especial value of the legumes lies in the fact that the forage is highly nutritious, being rich in the nitrogenous compounds called proteids. Not only are they valuable 
as forage, but they enrich the land upon which they are grown. By means of bacteria-like organisms inhabiting the nodules upon the roots, leguminous plants are able to gather nitrogen from the air. Part of this accumulated nitrogen is stored in the foliage but a part remains in the roots. This portion is added to the soil when the roots decay, and becomes available for the following crop. Thus it is that clover benefits the wheat that is grown later on the same soil.

\section{Other Forage Plants}

Aside from the two great groups already mentioned, there are few plants cultivated for forage. The most important are those of the mustard family of which the rape and turnip are examples. Another group occasionally cultivated are the salt bushes.

\section{FORAGE CROP AREAS}

The forage crop areas of the United States are classified on the basis of temperature and rainfall. All forage plants are limited to rather definite conditions of heat and moisture and a knowledge of the adaptability of the different species is necessary in choosing plants for different regions. The chief areas are the Cool Humid Region, the Warm Humid Region, the Semiarid Region, the Arid Region, and the Region of Winter Rains. These areas overlap in places and become indefinite in others but in the main they are fairly distinct.

\section{Cool Humid Region}

This area includes the northeastern states, extending south to the southern border of Virginia and Kentucky 
and further in the mountains, and west to eastern Kansas and eastern Nebraska. It is the region in which timothy can be successfully grown and hence is usually known as the Timothy Region. Other humid regions occur on the Pacific Slope from Puget Sound to northern California and in the mountain valleys of our western states. In the timothy region thrive the common meadow and pasture grasses, such as orchard grass, redtop and bluegrass, and the well-known legumes, red and white clover.

\section{W:ARM HuMid REgION}

This area extends from the Gulf of Mexico northward to the Cool Humid Region and west to eastern Texas. As the Cool Humid Region is known as the Timothy Region, so the Warm Humid Region is known as the Bermuda Grass Region and corresponds approximately with the Cotton Belt. Important forage plants of this area are Bermuda grass and Japan clover for pasture, and the cowpea and velvet bean for hay and soiling. Johnson grass here reaches its greatest development.

\section{Semiarid Region}

This lies west of the two regions already mentioned and includes all those portions of the Great Plains where crops can be grown without irrigation. Small areas, classed as semiarid, are scattered throughout the western half of the United States. They may lie in isolated valleys or in spots or belts at the base of mountains between the humid region above and the arid region below. In the moister portions of the semiarid region many farm crops, characteristic of the humid region, can be grown, 
such as corn, small grains, and cotton. This is especially true of certain varieties of these that have been developed to withstand the more severe conditions. Within recent years, the area of the semiarid region has been extended at the expense of the arid region. Land which was thought to be too dry for the cultivation of crops without irrigation, is now used for that purpose without other water than that supplied by the normal rainfall. To agriculture under these conditions has been applied the term dry farming. Dry farming has been made possible chiefly because of development along two lines. First, varieties of crops have been produced that are able to withstand a greater degree of drouth than those previously grown in the humid region, or, kinds of crops have been introduced from the semiarid regions of other countries. Secondly, methods of culture have been developed by which the soil moisture can be conserved and utilized to a greater degree than heretofore.

Among farm crops especially grown in the semiarid region may be mentioned durum or macaroni wheat, and emmer. Millet is a favorite forage crop in the eastern and northern portion of the area. Certain kinds of sorghum are commonly grown, especially Kafir, milo, Sudan grass, and a few varieties of sorgo, often here called "cane." Brome grass is a standard forage grass from Nebraska to Minnesota and Montana. Orchard grass and meadow fescue can be utilized further west than timothy can be successfully grown but are of no great importance in the region as a whole. The standard leguminous forage crop is alfalfa. Soy beans have attained some prominence in Kansas and adjacent 
regions. In the southern portion of the Great Plains, Johnson grass is an important factor in much of the region that is essentially semiarid.

\section{ARid Region}

This includes all that portion of the United States that is too dry for the growing of crops without irrigation. From the agronomic standpoint, it includes the arable land of this region to which irrigation water is supplied. Under irrigation, practically all kinds of crops can be grown, the regional distribution being limited or modified by temperature. The most important forage crop of the irrigated region is alfalfa. Timothy is grown in the arid region of Washington and some other forage crops are occasionally cultivated in limited quantities.

\section{REGION OF WiNTER RAINS}

This region lies on the Pacific Slope including the foothills of California west of the Sierras and extending north to Washington and Western Idaho. It lies east of the humid region already mentioned, which extends from northwestern California to Puget Sound, and includes the Palouse region of eastern Washington. As the rains come in the winter and the winter temperature is comparatively high, this season is utilized for the growing of crops, though the summer may be very dry. The most important crop of this region is small grain. Large quantities of grain are grown for forage, the product being called grain hay. This grain hay is, except alfalfa, almost the only hay on the market of much of this region. 


\section{USES OF FORAGE PLANTS}

According to the manner in which the forage is used, forage plants may be divided into four groups. Pasture plants, when grazed; Meadow plants, when the forage is dried, that is, converted into hay; Soiling plants, when the forage is cut and fed green; Silage plants, when the forage is preserved in silos.

\section{PASTURES}

In the broadest sense, a pasture is any area furnishing forage by grazing. Such are both the open range of our western states and fields of grain that furnish temporary grazing. In the usual sense a pasture is a fenced area of grassland intended primarily for grazing. As the present volume is concerned chiefly with cultivated forage crops, the subject of ranges and range grasses will not be pursued further here, but will be referred to briefly in Chapter X.

Pasture may be temporary or permanent. Temporary pasture can again be subdivided into two classes. The first class includes cases where the grazing is incidental, the crop being produced primarily for another purpose. Under this head come alfalfa fields grown for hay, but grazed at certain seasons; or winter wheat grown for the grain, but pastured during the fall or winter. Meadows are sometimes pastured at times, where such pasturage does not materially interfere with the crop of hay. Temporary pasture of this sort may be called incidental pasture.

The second and most important kind of temporary pasture is that produced from annual plants primarily 
sown for the purpose. The grains, corn, sorghum, Japan clover, crimson clover, soy (soja) beans, cowpeas, velvet beans, Canada field peas, vetches, rape, turnips, and some other annuals are used for temporary or annual pasture. Perennial grasses are also used for pasture during a single season, but detailed discussion will be deferred and taken up under the permanent pasture plants. The use of perennials for pasture during a single season depends upon the balance of cost of production and the value of the product. Under the modern system of intensive crop production in connection with dairying and other forms of animal industry, it may be an advantage to grow a perennial grass like timothy for the pasture crop of the first year. The yield may be larger the first year than in succeeding years. The larger yield and the desirability of a rotation of crops may determine the use of perennials for temporary pasture. Italian and English ryegrasses, being quick-growing species, are used for winter pasture in the South.

The annual plants most commonly used primarily for pasture are rye among the grasses, and rape and turnips among the cruciferous plants (mustard family). Japan clover is a common pasture plant in the south, but though an annual, is usually treated as a perennial, that is, it is not resown each year but reseeds itself spontaneously. The cowpea and velvet bean, annual legumes much grown in the Middle and Southern States for green feed, cover crops, and hay, are to an increasing extent, also utilized for grazing.

An important drawback to the use of annual plants for pasture is the large percentage of waste due to trampling. 
This loss may be greatly reduced by allowing the stock to graze upon a limited area each day. The fields may be of such a size in relation to the number of animals that practically the entire crop will be grazed off in a few days or before the trampled portion is killed or too greatly injured. Another method much used, especially for the smaller animals, hogs, sheep and poultry, is the confinement within movable pens or enclosures that are shifted from time to time within the field.

Under the system of farming commonly in vogue in the United States during the past, temporary pasture has been an incident. It has been for the purpose of utilizing a field that for the moment was lying idle, or it has been to meet an exigency such as the unexpected failure of the usual pasture crop, or to tide over some other emergency. In the modern system of agriculture, annual pasture plants are coming to have a definite place of importance. The yield is larger than that of perennial plants and annual plants are better adapted to systems of quick rotation. On the other hand the cost of production is greater for a series of years.

\section{Permanent Pasture}

The term pasture as commonly used refers to the herbage produced by perennial plants through a series of years. The advantages of permanent over temporary pasture has been mentioned under the discussion of the latter. Under favorable conditions there is a grazing crop each year without cost other than the original preparation and seeding, and small additional annual cost of up-keep, such as the repair of fences and, sometimes, the mowing of weeds, or the application of fertilizer. 
The great pasture grass of the humid region is Kentucky bluegrass or June grass as it is called in the more northern states. Under conditions favorable for its growth no other grass can successfully compete with this for pasture. In general it thrives throughout the humid region in fertile soil that is not too wet or that is not acid (see Bluegrass, page 58 ). Bluegrass finds the most favorable conditions for its growth on the limestone soils of the Ohio and the upper Mississippi Valleys, especially in the famous bluegrass region of Kentucky. By means of its numerous underground creeping stems, it forms a firm sod which tends to occupy the soil completely and thus exclude less desirable plants. The basal foliage which furnishes most of the forage, is proportionately abundant compared with the less succulent flowering stems. It starts its growth early in the spring and continues until late in the fall. The seed is easy to gather, and, if properly handled, should be of good quality and of reasonable price.

In the irrigated regions of the West, bluegrass may become a troublesome weed in alfalfa fields. Its agressive rootstocks enable it to supplant alfalfa, when, from any cause, the latter becomes weakened. As the bluegrass has much less value than alfalfa as a hay, its presence is looked upon with much disfavor.

Throughout the uplands of the Southern States-the warm humid region-the most important pasture grass is Bermuda. From Virginia to Florida and west to eastern Texas, except in the cooler mountain regions, Bermuda grass surpasses all other plants for pasture. It is nutritious and is relished by stock, and it withstands 
trampling as well as the dry hot summers. Although especially adapted to the drier uplands, Bermuda thrives in the valley lands and when grown here tends to become rank and is available for hay. These richer lands are, however, generally utilized for more valuable crops. The northern extension of this grass is limited by the cold winters.

Bermuda grass is preeminently a sun-loving or open ground grass. It languishes in the shade and is easily choked out by vigorous, shade-producing crops. It is this character that gives to this grass its value for the dry open uplands of the Cotton Belt. In the rich low lands of the Gulf Coast, it is crowded out in competition with two other grasses, carpet grass and St. Augustine grass. These grasses thrive especially on mucky soil. On sandy soil, even in the low lands, Bermuda usually holds its own.

Another plant, a legume, is adapted to the pasture lands under the same conditions that are favorable to Bermuda. This is Japan clover, a low annual, introduced from the Orient but now widely distributed in the warmer parts of America.

Various other plants are used to a limited extent in the South for pasture. Bluegrass thrives in the mountainous portions. Alfalfa is grown on the black prairie soils of Alabama and eastern Texas, but mostly for hay. Johnson grass is used for pasture in those areas where it has obtained a foothold, but is not so well adapted for this as for hay.

Valuable as is Bermuda for pasture, it becomes a troublesome weed in cultivated fields. There it grows 
much coarser and is known as wire grass. Because of its bad habits in fields of cotton and corn, Bermuda has received an unsavory reputation and its real value as a pasture plant is not always recognized or conceded. Like some other aggressive grasses, it is a valuable plant in its place.

In the semiarid region there are no characteristic pasture plants except brome grass, which is adapted only to the northern portion. Much of the permanent pasture of the Great Plains region is the native grassland. Much grazing is also obtained from alfalfa, grain, and sorghum. In the southern portion, Johnson grass attains importance. In the eastern part of the semiarid belt where the conditions are not too severe, orchard grass and meadow fescue are utilized.

In the northern part of the Great Plains, from Nebraska to Minnesota and Montana brome grass has been grown successfully. It is the only cultivated grass that can here withstand the conditions of drouth too severe for bluegrass, timothy, and clover. South of the region mentioned, the summer heat is too great for brome grass.

In the arid regions, the pastures are irrigated. The plants used under irrigation are alfalfa, especially in the more southern regions; various grasses of the cool humid region, especially bluegrass and timothy, these more particularly to the northward; and native grasses. Irrigated native pasture is likely to deteriorate if overirrigated, because of the intrusion of weedy species such as wire grass (a species of rush) and foxtail or wild barley grass. 


\section{MEADOWS}

A meadow, from the agricultural standpoint, is an area producing a growth of forage which is cut for hay. In this broad sense the term includes wild prairie grass, fresh or salt marsh grass, alfalfa fields, grain, sorghum, cowpea, or any other plant that is cut for hay. In the usual and more restricted sense, a meadow is an area of perennial or permanent grassland used for the production of hay.

\section{WILD HAY}

Immense quantities of hay have been produced from native grassland. Depending upon the source wild hay may be divided into three kinds (see page 146). The first and most important is prairie hay, derived from the native grasses of uplands as distinguished from marshes. As such land is capable of being tilled, the area devoted to hay is constantly decreasing, other and more valuable crops being grown instead. Prairie hay from the eastern portion of the Great Plains and the area lying just east of this, is nutritious and commands a good price in the market. It consists largely of bluestem and similar tall prairie grasses.

The second kind of wild hay is derived from fresh water marshes. Marsh meadows of this kind are scattered throughout the country. They attain great commercial importance in the northern part of the Mississippi Valley, notably in Wisconsin, Minnesota, and the Dakotas. These marshes are too wet for tillage during much of the season but become sufficiently dry during harvest to allow the cutting of the hay. In some localities broad 
shoes are placed upon the horses' feet to prevent them from sinking into the soft soil during the mowing. The most important grasses of these marshes are a kind of bluejoint (different from the bluestem of the prairies), and reed canary grass.

The third kind of wild hay is derived from salt marshes. Vast areas of salt marsh are found along the seacoast of the United States, especially that of the North Atlantic. The hay derived from salt marsh is usually of poor quality for forage but is utilized extensively for packing and stable litter.

\section{Grain HaY}

The small grains are well adapted to the production of hay and are used for this purpose whenever the value of the hay exceeds the value of the grain or when conditions justify the sacrifice of the grain. From the commercial standpoint, grain hay attains prime importance only on the Pacific Coast and portions of the area lying to the eastward. The lack of other sources of grass hay in this region has led to the utilization of grain. Besides the hay that is produced from wheat, barley, and oats, a not inconsiderable amount is derived from volunteer crops of wild oats.

\section{Legume Hay}

Although this volume is concerned primarily with the grasses, a few words will not be out of place regarding hay derived from leguminous plants. The most important hay plant of the west is alfalfa. And its importance is on the increase in the eastern United States. Next in importance of the legumes in the hay market is 
red clover. This plant is grown throughout the cool humid region and furnishes much more hay than the proportion on the market would indicate. A large part of that produced is consumed on the farm. Although it appears on the hay market, it is in less demand than timothy. This is because it is not considered so well adapted to horses as is timothy. A large amount of clover is grown mixed with timothy, this mixture also being used chiefly on the farm. Alsike clover is grown in many localities, but much less in quantity than red clover, and chiefly in places too moist for the latter.

In eastern Canada and in the adjoining portion of the United States, hay is obtained from field peas. The most important leguminous hay in the South is the cowpea. Other leguminous plants used for hay are the velvet bean in the South, crimson clover from New Jersey to North Carolina, the soy bean in the Southern and Middle States, and the vetches in the cool humid region and as a winter plant in the South.

\section{Coarse Hay or Fodder}

In the wide sense the dried product of the large grasses is hay, but it is commonly referred to as fodder. The best known fodder comes from corn or maize. When corn is grown for the grain, the fodder is utilized so far as it can be without interfering with the production of grain. Over much of the Corn Belt, the ears of corn are gathered from the standing plants and the stalks are allowed to remain in the field over winter. These stalks are usually utilized by turning stock into the field after the ears are removed. The matured and weathered 
fodder has little feeding value, but nubbins and waste ears are saved.

Another method of harvesting corn is to cut the stalks before the ears are mature and while the foliage is green. The stalks are placed in bunches or shocks to dry in the field. The grain matures while the fodder is curing, and the ears are husked from the shock by hand or by machinery. The fodder produced in this way contains much nutriment, its value depending on the stage at which the stalks were cut and upon the amount of weathering.

A large amount of fodder is produced from sorgo, Kafir, milo and other kinds of sorghum. In the Great Plains region, sorgo is often called cane. Sorgo is frequently grown for fodder alone, in which case it is usually sown thickly so that the individual stalks are slender and succulent. Corn may be grown in this manner also, that is for fodder and not for the grain. Kafir corn may be grown for the grain but, like corn, the stalks and foliage can be utilized for fodder after the seed has been removed.

Other grasses used in small quantities for fodder are teosinte and pearl millet. The foliage of sugar cane is used in the area where this plant is grown.

\section{Millet}

This is the only annual species among the smaller grasses that is grown to any considerable extent primarily for hay. The area where it is used extensively extends from Texas to Minnesota. Included under the general head of millet or foxtail millet, are common 
millet, Hungarian grass, and Golden Wonder millet. Another kind of millet called proso is grown to a limited extent especially northward. This is called also broomcorn or hog millet. Sudan grass has assumed prominence in recent years.

\section{Ordinary Meadow Hay}

Under this term is included the hay made from the cultivated perennial meadow grasses. The most important and best known meadow grass of the cool humid region is timothy. This is the standard hay of the market and is a basis of comparison for all others. Redtop is produced in considerable quantities in the acid or moist soil of the same region, especially along the Atlantic coast from New England to Maryland. In the Southern States especially in Texas, Johnson grass is extensively utilized. Brome grass is used in the region from Nebraska to Montana and Minnesota. Orchard grass and meadow fescue are of some importance in the cool humid region. Rye grass is sometimes grown for hay, especially in the South as a winter crop.

\section{SOILING}

The process of cutting forage and feeding green is known as soiling. This method of utilizing forage is only practicable in connection with intensive farming, such as dairying. The labor is greater and the waste less than in pasturing. Annual plants such as the grains, and some coarse fodder grasses such as corn, sorghum, and teosinte are the usual soiling plants. In the tropics hay is seldom produced as the conditions permit the growing 
of forage throughout the year. Here soiling is the usual method of feeding animals. The grasses most commonly cultivated for this purpose are Guinea grass and Para grass.

\section{Silage}

The advantage of feeding green forage by soiling is so evident that agriculturists desire to continue, if possible, the feeding of succulent forage throughout the year. This is now made possible by means of silos. The green feed is preserved or canned and fed as wanted during the year. A silo is a large tank or room, in which green forage is placed, the air being excluded so far as practicable. The forage starts to ferment but this process ceases as soon as the entangled air is used up. The material remains in the slightly fermented condition until removed for feeding. If the silo is poorly constructed and air gains entrance, the fermentation continues and the whole mass may become rotten and useless. Although any forage plant may be preserved in a silo the. plant most used for the purpose is corn.

\section{NOMENCLATURE OF GRASSES}

The common names of grasses are those by which they are known in the language of the countries in which they grow spontaneously or in which they are cultivated. The English name of cultivated grasses varies in different countries. What is known in the United States as orchard grass is called in England cock's foot. Even in the United States, a grass may be known by more than one name or the same name may be applied to more than 
one species. Timothy is also known as Herd's grass and the name Herd's grass is also applied to redtop. In order to standardize names, that they. may be understood by botanists in all countries, Latin names have been applied to plants. Botanists have classified plants into families, the families into genera, the genera into species. The grasses form a distinct family among plants. For convenience, the grasses have been divided into smaller groups. There are about 20,000 species or kinds of grasses. These have been grouped in about 400 genera. Each genus includes the species that resemble each other, the classification being based on the structure of the flowers. A Latin name has been given to each genus. To the bluegrasses, including Kentucky bluegrass, Canada bluegrass, Texas bluegrass, and many wild species all over the world, has been given the name Poa; to the bent grasses, including redtop, Rhode Island bent, carpet bent, and a large number of wild grasses that closely resemble these, has been given the name Agrostis. The species or particular kind in each genus has received a Latin name. Botanically, each kind of grass is known by the Latin name of the genus and species to which it belongs. Bluegrass is called Poa pratensis; Canada bluegrass, Poa compressa; Texas bluegrass, Poa arachnifera, and so on. The first part of the Latin designation is called the generic name; the second part, the specific name. In this book is given the Latin or botanical name of each grass described. This is done in order that botanists in this country and in other countries may know with certainty the kind of grass described or mentioned. 
It is customary to place after the Latin name of a plant the name of the botanist who placed the species in the genus to which it is assigned, the name, for convenience, being abbreviated. This enables botanists to investigate further, if they wish, the botanical history of the grass. As Linnaeus, the famous Swedish naturalist, was the first to place Kentucky bluegrass in the genus Poa, the species is written Poa pratensis L. A second name is sometimes placed in parentheses. This indicates that the species had previously been included in another genus and was transferred to the present genus by the botanist whose name, or its abbreviation, stands after the parentheses. The botanical name of Bermuda grass is Capriola Dactylon (L.) Kuntze. Linnaeus placed the species in the genus Panicum and Kuntze transferred it to the genus Capriola. 


\section{CHAPTER IV}

\section{CULTURE OF GRASSES}

THE culture of grass crops is governed by the same general principles that are applicable to other farm crops.

\section{GENERAL PRINCIPLES}

To produce the best results, ordinary meadow grasses require a fertile, well drained soil. Of course there are soils upon which, because they are sandy, rocky, alkaline, or are too wet or too dry, average crops cannot be grown. Upon such soils it may be possible to grow species especially adapted to them, and such grasses may require special methods of culture. These requirements are mentioned under the paragraphs devoted to the individual grasses. The methods of culture are similar to those used in the growing of grain, in practically all regions where grain is raised.

\section{PREPARATION OF THE SOIL}

Meadow grasses have small seeds, hence require a soil that has been put in fine tilth in which they may be lightly and evenly sown and not deeply buried. A coarse lumpy surface causes waste of seed, for much of it will be placed in such unfavorable environment that either it will fail to germinate or fail to live and grow after germination. The depth of plowing must depend upon circumstances. Under usual conditions the drain- 
age and tilth is improved by deep plowing but soil which has been shallow-plowed for several years may be injured by suddenly deepening the plowing and bringing the sterile subsoil to the surface. In such cases it may be best gradually to deepen the plowing, bringing to the surface only a small quantity each year. In the Great Plains region where strong dry winds prevail in the spring, deep plowing may be a distinct injury as the soil is sometimes blown away to the depth of the plowing. Here it may be necessary to disk or to drill in stubble without plowing.

\section{SOWING THE SEED}

Grass seed is sown broadcast or with a drill upon properly prepared soil. In general it takes less seed per acre when a drill is used. Not all kinds of grass seed can be sown with a drill. Sorts with fluffy or chaffy seeds do not feed regularly through the machine, though they can often be made to do so when mixed with sand. Broadcasting by hand is the primitive way to sow grass, grain, and small seeds generally, and an expert can scatter them with surprising evenness. There are many devices, such as the wheelbarrow seeder, now sold, by which the seed can be broadcasted mechanically. These machines scatter the seed more evenly than can usually be done by hand, especially by the modern farmer who has less practice in this kind of sowing than had his grandfather.

Seeds that are large enough to allow of being planted an inch below the surface are now usually sown with a grain drill. This machine places the seed at a uniform depth 
and distributes the seed more economically than does broadcasting.

Grasses are not usually planted in rows for cultivation when grown primarily for forage, though the larger kinds often are when grown for seed.

\section{CARE OF PASTURES}

Temporary pastures which form part of a rotation will be considered in another paragraph. Here a few words will be said about the care of permanent pastures. On fully developed farms, the land usually devoted to permanent pastures is likely to be that land which cannot be utilized for crops. It may be too rough or rocky, or land partially covered with timber, or land lying along streams or ravines. In the humid region such land is naturally or artificially seeded to bluegrass, or a mixture of various grasses, but in which bluegrass is likely to dominate on the drier portions. There are a few general principles which apply to all pasture lands to keep them from deteriorating.

In the first place care should be taken that pastures are not overgrazed. The number of head of stock which a given area will support depends upon conditions and must be determined by experiment. The stock eat the most palatable growth first, hence weeds and undesirable plants are left to flourish unrestrained. Within limits the natural growth of the grass will keep the weeds in subjection but if the pasture is over-grazed, the weeds soon get the upper hand. If coarse weeds become prominent in a pasture it should be mowed occasionally so as to give the grass a better chance to overcome them. It 
is a fallacy to suppose that close grazing will keep down weeds.

Another important point in preventing the deterioration of pastures is to keep stock off when growth starts in the spring. The growth of grass should be allowed to reach 2 or 3 inches before cattle are turned into the pasture unless the number is so small that there is no danger of retarding the growth of the grass. If the green parts are kept too closely grazed, the plants do not have an opportunity to generate strength for the season and hence tend to die out. It is true that if the grass gets ahead of the cattle and begins to head out the cattle do not relish it so much, but in such cases the pasture can be mowed to start new growth. Drouth soon reduces the carrying capacity of a pasture and much damage may result if it is full-grazed during such a period.

Unless a pasture is fertilized at intervals, its carrying capacity gradually decreases. Top-dressing with barnyard manure renews the fertility. In the absence of a supply of manure, artificial fertilizer may be used. Small quantities applied often give better results in the aggregate than larger quantities applied infrequently. Of artificial fertilizers, potash and phosphoric acid are likely to give the best returns. Low or wet land is usually improved by the application of lime. It is best not to apply lime at the same time as other fertilizer as it tends to release the nitrogen.

If a pasture becomes run down, rejuvenation may be helped by reseeding with a mixture of bluegrass, white clover, redtop, and timothy. Timothy gives the quickest returns but soon runs out. 
If the pasture is such as to allow of plowing it can best be rejuvenated by plowing and reseeding as described under temporary pastures.

\section{CARE OF MEADOWS}

There is little to be said concerning the care of permanent meadows beyond calling attention to the fact that by continually cutting and removing the hay the fertility of the soil is gradually reduced. Some soils are of such a structure that the deterioration is not noticeable for several years. The loss of nitrogen and usually of potash or phosphoric acid will reduce the yield perceptibly in a few years. Hence it is necessary to fertilize mead ows in the same way as mentioned above for pastures.

Lowland meadows that are subject to overflow may receive fertilizing material by the deposit of silt. The meadows around the Bay of Fundy in Nova Scotia are regularly fertilized in this manner. Dikes are built to keep out the sea water but at intervals of several years the meadows are flooded at high tide, when a thin coating of silt or ooze is deposited. During the first season the rains wash out the excess of saline matter and the meadows are rejuvenated.

\section{MAKING HAY}

The methods of making hay are so well known that the process in general will not be described in detail. Machinery for making hay is now in such general use that hand methods will be passed over. The grass is cut with a mowing machine and allowed to cure, after which 
it is stored in stacks, sheds, or hay mows. This sounds very simple, and under favorable conditions the process is as simple as it sounds. The difficulties arise in the process of curing when the conditions are not favorable. If the grass is wet with rain when partly cured, or if the atmosphere is so humid that the moisture from the grass cannot be removed, it deteriorates rapidly in quality and may mould or decay. If the shower or wet spell is followed by favorable weather, the hay may be recovered without much loss. If it had been raked into windrows or put into bunches or cocks, it usually becomes necessary to spread the hay for drying. Tedders which pick up and scatter the hay are useful in handling a heavy crop in the swath or scattering it when put in the windrow. A small amount of moisture may detract from the appearance of hay without injuring its nutritive value. But thorough wetting, especially after the hay is partly cured, causes a rapid deterioration in the feeding value. If hay is put up when damp or before being thoroughly cured it may ferment or mould. Sometimes the heat produced by fermentation is sufficient actually to burn or carbonize the hay.

In wet climates, various devices are used to aid in curing hay. The simplest is to throw the partly cured hay into cocks at the approach of a shower and cover with some kind of an impervious cover such as canvas or specially prepared paper or pasteboard hay caps. On the return of favorable weather the cocks are opened to dry. In some cases the freshly cut grass is put up in drying sheds. These consist of a series of open framework floors upon which the grass is placed in layers thin 
enough to dry by ordinary air circulation, the whole being under a roof. In wet, tropical countries, artificial drying machines have been used. The grass is dried by a current of hot air. The machines are effective but costly.

The time to cut grass for hay depends somewhat on the kind, but in general it should not be cut much before flowering nor as late as the ripening of the seed. The aim should be to obtain maximum weight and maximum nutritive qualities. The weight increases up to the time of the maturity of the seed, but the nutritive quality decreases after flowering. Usually the combination is greatest about half way between flowering and maturity. Hay cut when in flower, however, usually has higher nutritive quality. Furthermore, while the nutriment is in the leaves as it is in the earlier condition it is more available to stock than when it is mostly in the stems as it is later, because the stems are not so readily eaten By nutritive quality as here used is meant palatability combined with digestibility. The value of hay depends in large part on how much the animal is willing to eat.

\section{GRASS IN ROTATION}

Most of what has been said above in regard to care refers to permanent meadows or pastures. In considering the question of temporary pastures or meadows, certain aspects appear which modify greatly the method of procedure. In permanent pastures the element of labor beyond the first year is insignificant. Consequently a lower return of interest on the investment is permissible. The yield of permanent fields after the 
first 2 or 3 years decreases considerably. It is evident that the greatest return in yield is obtained when the fields are reseeded as often as every three years. It is for this reason that grass occupies a prominent position in nearly all systems of rotation. A meadow gives its greatest yield the first crop year and a fair return the second crop year. Hence in a rotation a field can be used one or two years for meadow, followed by one or two years of pasture. Where the land value and cost of labor permit, the best results are likely to be given by one year of meadow and one year of pasture. This of course is followed by a cultivated crop of some kind and, somewhere in the series, by a leguminous crop. In such a system there is little trouble from weeds and, because of the high state of fertility maintained, the yield is high. Since rotation of crops is a subject which has to do with general farm practice it will not be further discussed here.

\section{GRASS SEED}

Success in the growing of forage crops can scarcely be attained unless pure viable seed is used. Timothy seed is now grown on such a large scale, and under conditions so favorable for the production of the first grade seed that a satisfactory quality may be obtained of this important forage grass. The seed of many other kinds is not infrequently low in viability or mixed with weed seed or with chaff.

By viability is meant ability of the seed to germinate. The seed of corn or wheat as ordinarily used by the grower has a viability of nearly Ioo per cent, that is, nearly every seed will grow if placed under the proper 
conditions. But much grass seed as sold on the market may show a viability of very much less than Ioo per cent, sometimes not over 50 per cent, while in poor grades it may be reduced to zero.

If seed has nothing wrong with it except its low viability, no great harm may ensue. There is the loss due to paying more for the seed than it is worth and the disappointment arising from a poor stand. Much more serious is the adulteration with poor and cheap varieties or the presence of weed seeds. Not only is there less good seed but there is the danger of establishing pernicious weeds difficult to eradicate.

The quality of the seed may be reduced by the presence of foreign seed (seed other than the kind purchased) some of which may be pestiferous, or by presence of inert matter such as dirt, chaff, or old seed. It is evidently to the advantage of the grower if he be able to test his seed and determine for himself if it be of good quality both as to germinating power (viability) and purity-that is freedom from weed seeds and chaff. The farmer can always obtain information as to the quality of his seed by sending a sample of it to the director of his State Experiment Station or to the Seed Laboratory of the U. S. Department of Agriculture.

The farmer can determine for himself the viability of his seed. He can also determine the purity, though it requires expert knowledge to identify the particular kind of foreign seed that may be present.

To determine the purity it is only necessary to examine a sample with care. Spread it out on a piece of white paper and separate all dirt, chaff, or withered seed and 
estimate the proportion of good seed. A small magnifying glass is a help in this work as many of the grass seeds are small (fig. I). If one wishes to know accurately the proportion of good seed it is necessary to weigh the sample and afterwards to weigh the good seed. As farmers usually do not possess balances for weighing such small amounts and as these instruments are expensive, it is best to send samples to an experiment station. How-

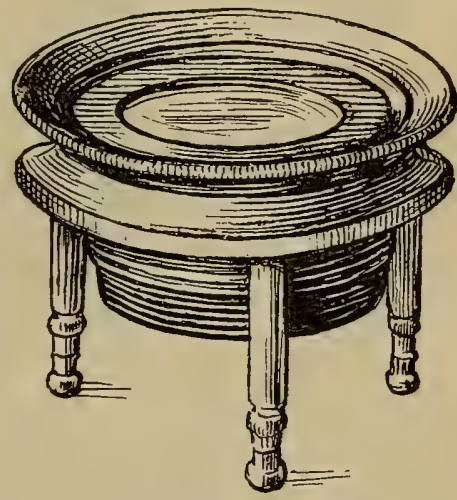

r. Magnifying glass suitable for testing the purity of seeds. can be made without accurate weighing.

The seed of grasses is enclosed in chaff which is not usually removed in threshing. Timothy seed is fairly free from chaff but seed of bluegrass and most other grasses has a rather large proportion of chaff. The value of seed depends, of course, on the amount of good seed as distinguished from the chaff. The weed seeds can be easily separated, and if there is more than a very small amount, the grass seed should not be used for sowing. In examining the seed of bluegrass, redtop, etc., one should pick out the actual seed with a needle or other small sharp instrument, so that he may know just what he is looking for. A good seed is hard to the touch like a grain of wheat (on a small scale) or a timothy 

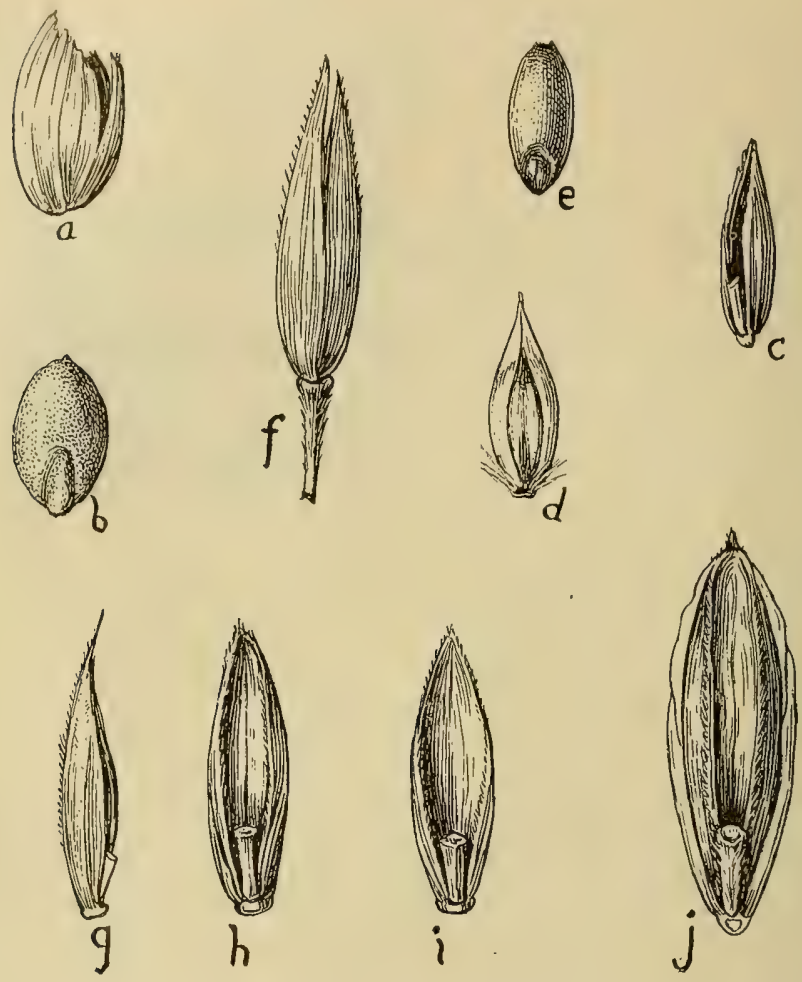

2. Seeds of some common grasses as they appear in commercial samples. $a$, timothy enclosed in chaff. $b$, timothy free from chaff. $c$, bluegrass, a single floret from a several-flowered spikelet, the seed being enclosed in the chaff (lemma and palea) the joint of tha rachilla showing on the concave side. $d$, redtop, a seed enclosed in its chaff (lemma and palea). $e$, redtop, the naked seed. $f$, redtop, the outer chaff or glumes. Well-cleaned seed should consist mostly of seed like $d$ and $e$ and should be nearly free from tha coarse chaff like $f . g$, orchard grass. $h$, meadow fescue. $i$, English or perennial rye grass. $j$, brome grass. In figurers $g$ to $j$ the spikelet has been broken up in threshing so that there is presented a single floret with a joint of the rachilla. 
seed. Chaff with no seed inside is soft and collapses when pressed with a needle. Some of the common grass seeds are shown in figure 2.

Seed not infrequently is adulterated with various things, especially with old seed. The mixture looks all right but will not grow well.

It is to be recommended that every grower also test the germinating power (viability) of the seed he is going to use. This is a simple process and well repays the small amount of trouble required. He can then know what results he may expect and whether in purchasing his seed he has obtained the worth of his money.

To test germination it is only necessary to place the seed under favorable conditions as to temperature and moisture. Most progressive farmers now are in the habit of testing seed corn for viability and hence will readily understand how to handle grass seed for the same purpose.

The seed may be spread upon moist sand or upon wet cloth or blotting paper, and should be kept for several days at a fairly uniform temperature, about that of living room. Soup plates make convenient germinators. A plate is partly filled with clean sand and the sand saturated with water. Upon the sand is placed a sheet of blotting paper or a piece of Canton flannel. The seed to be tested is placed upon the paper or cloth and covered with a second layer of paper or cloth. There should be enough water to saturate the sand and the covers but not enough to show an excess of liquid so that the seeds lie in water. A second soup plate is inverted over the first to prevent drying out. The germinator is placed 
where it will not be too hot in the day time nor too cold at night. It is best to maintain a temperature of 60 to So degrees Fahrenheit. The sand should be kept saturated with water. Some seeds are likely to germinate in 4 or 5 days but the test should be continued for as much as two. weeks. The seeds are removed as fast as they sprout and a record kept of the number. For accurate results the seed sample should be weighed and a count made of the seeds to be tested. The result can then be expressed in percentage of germination. However, a very fair estimate can be made by a small sample of, say, a spoonful for the test. The seed should be well mixed before the sample is taken. It is well to try more than one sample so as to get an average.

Timothy seed is usually nearly Ioo per cent pure and the viability is high, usually 98 per cent or more. Hence it is recommended to those who are not familiar with home testing that they try a sample of timothy along with any other seed to be tested. This acts as a check on results. Bluegrass is usually mixed with much chaff, even the best grade containing Io to 20 per cent of chaff, and the viability is likely to be 65 to 80 per cent. But poor grades will run much lower in both purity and viability. The seed to be tested should be examined for purity to see that it is not adulterated with some other kind of seed. And in counting the germinating plants no record should be made of plants other than the kind tested. A reference to the figures of the common kinds of grass seed will aid in determining purity. Orchard grass, meadow fescue, and red top should show a viability of 95 per cent; brome grass of as much as 90 per cent. 
That is out of 100 seed tested 95 or 90 should germinate in about 2 weeks. Of course the actual percentage can not be determined unless a definite number of seeds had been counted out. But as said before a rough estimate of the quality can be made, without counting.

It is evident that the price to be paid for seed depends on the purity and viability. Of the ordinary pasture and meadow grasses timothy is the only one that, when purchased of reliable dealers, is likely to show nearly Ioo per cent purity and viability. Others, especially Kentucky bluegrass, show great variation. Low grade seed is dear at any price and high grade seed may not always be above suspicion. Much of the failure to obtain good results with grasses other than timothy may be due to using a poor quality of seed. It should be borne in mind that the farmer always may have recourse to his State Experiment Station or to the Seed Laboratory of the U.S. Department of Agriculture. A full account of seed testing may be found in Farmers' Bulletin (U. S. Dept. Agriculture) no. 428 entitled Testing Farm Seeds in the Home and in the Rural School, by F. H. Hillman. This bulletin may be obtained on application to Secretary of Agriculture. 


\section{CHAPTER V}

\section{THE STRUCTURE OF GRASSES}

IN order to understand the descriptions of the grasses set forth in the following pages, it will be necessary to learn something of the more important parts and organs of the grass plant.

Grasses are distinguished from other plants by the jointed stem, and the long narrow parallel-veined leaves placed in two opposite rows along the stem. The structure of the flowers is characteristic and will be explained in a separate paragraph. Typical grasses are exemplified by timothy, bluegrass, and wheat. Other members of the grass family are certain larger plants that are not always associated with the typical forms mentioned above. Among such are corn, sorghum, sugar cane, and bamboos. Some plants belonging to other families resemble grasses in having long narrow blades. Among these may be mentioned sedges, rushes, and certain kinds of lilies. In all these the structure of the flowers is different. But aside from the structure of the flowers, the sedges, the family which most nearly resembles grasses, may be distinguished by the arrangement of the leaves. As stated above the leaves of grasses are arranged along the round or somewhat flattened stem in two rows and are said to be 2 -ranked. In sedges the leaves are arranged in three ranks and the stem is often 3-sided or 3-angled. 
The structure of grasses will be explained under the following heads: root, rootstock, stem, leaf, flower.

\section{ROOTS AND ROOTSTOCKS}

The underground parts of grasses are popularly known as roots but are of two kinds, differing in structure and function, the true roots serving the purpose of taking up water and food from the soil, the rootstocks serving for propagation.

Root.-The roots of grasses always consist of clusters of slender fibers such as shown by wheat or oats when pulled from the soil.

.The ends of the rootlets are covered with fine hairs (root-hairs) giving them a velvety appearance. By means of these the roots are able to absorb water from the soil, and, dissolved in the water, the mineral substances present in the soil, these being the food of the plant. Certain underground parts that are often confused with roots are described in the following paragraph.

Rootstock.-This is a modified stem which creeps underground. It bears roots and small modified leaves or scales, and sends up at intervals shoots which develop into ordinary stems and leaves. The function of rootstocks is to propagate or spread the plant. Rootstocks are found in bluegrass, Johnson grass, Bermuda grass, and others. Grasses with rootstocks are always perennial. The part above ground may die but the rootstocks remain alive over winter and send up shoots the following spring. Rootstocks are also called rhizomes. 


\section{STEMS AND LEAVES}

The vegetative parts of grasses, the green parts above ground, consist of stem and leaves.

Stem.-The stem is the central axis of the plant which bears the leaves and finally the flowers. In most of the common crop grasses the stems are simple and upright, that is they are not branched above ground. However, nearly all grasses stool. This stooling is a vigorous branching at the base, as shown typically by wheat. In technical descriptions the stem is called the culm.

The stem is usually round (cylindric) but is sometimes somewhat flattened, distinctly so in Canada bluegrass. It is divided into sections (jointed) separated by nodes (joints), the slightly swollen places, discerned distinctly in the straw of wheat and other grains. Many grass stems are hollow, as in wheat, but may be solid or pithy as in corn, sorghum, and Johnson grass. At each node is borne a leaf. In many grasses the nodes are close together at the base of the stem. The crowding of the nodes produces a crowding of the leaves, the latter thus appearing in a tuft at the base. This is true of nearly all perennial grasses such as bluegrass and rye grass. The early shoots remain short with crowded leaves. The stem elongates only when the plant is ready to produce flowering shoots:

In a few grasses, such as Bermuda grass, the plant produces slender stems or runners which creep along the surface of the ground, taking root at the joints and sending up flower-stems. Such creeping stems are technically known as stolons. 
Leaf.-The leaves are the foliage organs of the plant. They may be crowded in tufts as already described or may be scattered along the stem. In our common meadow and pasture grasses the stems remain short in the early part of the season and the foliage is thick and tufted close to the ground. Later the long flower stems are produced. After the ripening of the seed the flower stems wither away and during the remainder of the season the grass continues in the tufted condition.

The leaves invariably arise from a node or joint of a stem, one leaf to each node. This arrangement is distinctly seen in larger grasses like corn or sorghum. A leaf consists of two parts, the sheath and the blade. The sheath is wrapped around the stem, usually for some distance above the node. It is usually split on the side opposite the blade, one side of the sheath overlapping the other. The blade, commonly called the "leaf," is attached at the upper end of the sheath; it is usually narrow, flat, and gradually pointed. A strong vein or vascular bundle passes along the center from base to apex, and on each side parallel to the mid-vein, are several delicate lateral veins. These veins are also known as nerves. They consist of minute tubes for the conduction of sap from the stem into the leaves. By holding a thin blade up to a strong light, numerous minute cross veins may be seen. At the base of the blade where it joins with the sheath is a delicate membrane running up around the stem for a short distance. This is called the ligule. It is usually less than one-half inch long, often much shorter, sometimes so short as to be detected only with a lens. 


\section{FLOWERS AND SEED}

The reproductive parts of the plant consist of flowers, which in turn produce the seed.

Flower.-The individual flowers of grasses are arranged in spikelets, which are usually small and inconspicuous, but nearly always are aggregated in clusters or masses technically known as the inflorescence. The inflorescence of the grains and most of our common grasses is known to the layman as the flower or seed head. And when the inflorescence appears the plant is said to be headed-out. The flower cluster or head may be dense as in timothy and wheat, or open as in oats and bluegrass.

The unit of the inflorescence or head is the spikelet. This can be easily observed in wheat or oats. The wheat head consists of a central flattish zig-zag axis with a row of spikelets on each side. The spikelets are fastened at the joints of the axis, alternating with each other on the two sides, those in each row overlapping. In oats the spikelets are hanging from slender branchlets of the inflorescence. In timothy the spikelets are very small and flat, and are crowded in a dense cylindric mass or head.

The spikelet contains the individual flowers. The familiar wheat spikelet will illustrate this. The flattened spikelet consists of several overlapping scale-like bracts (fig. 3). These bracts are in two rows and when removed are boat-shaped. In bearded wheat some of the bracts extend into long bristles (the beard). If a wheat spikelet is examined at the time the wheat is in flower, it will be found that the middle bracts, when pulled apart, contain 
a flower, that is, a pistil and three stamens. If the wheat heads are observed in the early morning, about sunrise, the bracts will be seen to be open or spread apart, and the two feathery tops of the pistil and the three slender stamens will be hanging out. The stamens will be shedding the pollen at this time. A light gust of wind or a touch of the hand will send the pollen flying in little clouds.

The structure of the spikelet is as follows: on the outside or bottom is a pair of empty bracts, that is, when pulled apart there will be no flower within. The third and following bracts except one or two small ones at the top, contain each a flower. Later
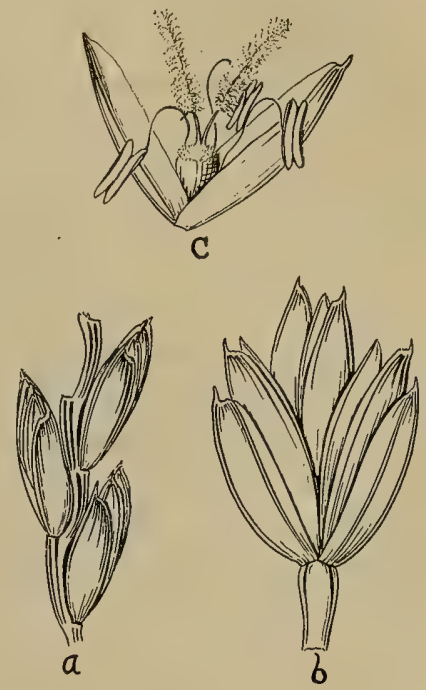

3. Spikelet of wheat: $a$, portion of axis with 3 spikelets; $b$, a single spikelet; $c$, a floret. the flower is succeeded by a seed or grain. The two lower bracts which contain no flower nor grain, are technically known as glumes. The following bracts, those that contain flowers and later the grains, are called lemmas. Behind each grain is found another little bract. This is called the palea. The spikelet of wheat is said to be several-flowered. The spikelet of the oat is 2 -flowered or 3 -flowered. In these the lemma in some varieties has an awn or bristle on the 
, back. The spikelets of redtop and of timothy are very small and are I-flowered, consisting of a pair of glumes and a lemma and palea.

The spikelets of wheat and oats are large enough to be examined easily with the unaided eye, but the spikelets of some grasses, such as redtop and timothy, are so small (only I/I2 inch long). that a hand lens or small magnifying glass is needed to make out their structure satisfactorily.

The botanical classification of grasses is based upon the structure of the spikelets, and a botanical description emphasizes the details of these, but in the present work, which is agricultural rather than botanical, the descriptions of the spikelets are brief and include only such details as can be seen easily without dissection.

Seed.-The seed is always developed from a flower. In grasses a single seed is developed from each flower, and each spikelet may produce as many seeds as there are perfect flowers. When the seeds are rather large they are usually known as grains. This term is applied especially to corn and the cultivated grasses known as "small grains," such as wheat and oats. On the other hand the term grain is not applied to the small seeds of redtop, bluegrass, and timothy. Botanically the socalled seed of grasses is a fruit. The "seed" or grain of wheat is a fruit (ripened ovary) containing a single seed which is grown fast to the walls of the fruit to form the grain. When a grain of corn is soaked in water the enclosing fruit can be peeled off as a separate covering leaving the actual seed. For practical purposes the seed and fruit of grasses are, the same and in this work 
are so considered. That is, in the description of the grasses, what is really the fruit is referred to as the seed, or in case of the large fruits, as the grain.

In corn, wheat, rye, and some other grasses the seed (fruit) separates from the chaff of the spikelet (the glumes and lemmas), and, when threshed, comes into the market as a naked grain or seed. In many others the seed remains permanently enclosed in the lemma and palea. To this group belong oats and barley. A grain of oats or barley is, then, a covering of chaff, the lemma and palea, with the real grain or seed inside. This grain can be removed by cutting away the eniclosing chaff.

The commercial seed of bluegrass and redtop consists of the broken up spikelets, each seed being enclosed by the lemma and palea. In these and many other meadow and pasture grasses the commercial seed is an uncertain mixture of chaff and viable seed. The seed is so light that in threshing and cleaning it is not separated from the chaff, or at least very incompletely so. Furthermore many of these grasses do not ripen all the seed of the head at the same time, nor do all of the heads ripen, even approximately, at the same time. Therefore when a field is harvested, there is a comparatively small percentage of ripe seed in the harvested heads. When these heads are threshed, the resulting seed, as it is offered for sale, consists of a rather small amount of ripe viable seed mixed with a varying amount of chaff. Timothy is one of the few meadow grasses in which the seed is little diluted by chaff. The heads ripen about the same time and the ripe seed can be rather easily separated from the chaff. In sowing timothy one has a fairly accurate 
knowledge of the condition of the seed and can calculate the amount to sow per acre. With other grasses such as bluegrass and redtop, only a careful examination with a magnifying glass will reveal the proportion of viable seed and then only approximately and often uncertainly. A closer approximation can be made by germination tests. The latter is really the only practicable method to determine the value of commercial seed of most of our meadow and pasture grasses (see Chapter IV). It is evident from this that the farmer who is not in position to determine for himself the value of his seed must depend upon the reliability of his seedsman. The selling price of seed should be an indication of its purity. It is advisable to purchase the best grade at a higher price. 


\section{CHAPTER VI}

\section{THE THREE LEADING FORAGE GRASSES}

Among all the grasses that are cultivated in the United States for forage, three stand out preeminently. These are timothy, bluegrass, and Bermuda grass.

\section{TIMOTHY}

Timothy is the most important meadow grass in America and timothy hay is the standard hay upon the market, the criterion by which all other hay is measured. It was one of the earliest grasses to be cultivated in this country for hay and at once became dominant. While timothy is no more nutritious than many other grasses it has other qualities that cause it to be favored above all other meadow grasses in the regions where it thrives. The seed is cheap and reliable, and of a nature that renders it easy to handle and to sow. It is borne in a compact head; the heads are formed at a fairly uniform height from the ground; the seed ripens approximately at the same time, does not shatter much, and is produced in abundance. All these qualities tend to keep the price of the seed low. Good seed at low price would in itself place any grass in a favorable position in the estimation of growers. To these advantages should be added those of being palatable, nutritious, easily grown and harvested and of covering the ground evenly rather than in tussocks 
as in the case of orchard grass. For these reasons timothy occupies a dominating position in the agriculture of the humid region, a position from which it is not likely to be displaced by any other grass now in cultivation.

The region in which timothy thrives is the same as that favorable to bluegrass, that is, the humid region. In general this is the northeastern states and south to the southern boundary of Virginia and Kentucky, and further south in the mountains, and west to about the ninety-sixth meridian; and in the western mountains in the Puget Sound region. Timothy can be grown up to about I0,00o feet in the mountains of Colorado and to a correspondingly lower altitude further north. It: can be grown under irrigation in the more northerly arid regions but does not thrive in the southern portion of the United States even under irrigation.

The importance of timothy is shown by the statistics from the Census Report for I909 (see page 7). The acreage of timothy in the United States was $14,686,393$ of timothy and clover mixed, $19,542,382$; the production in tons, timothy, I7,985,420, timothy and clover, $24,748,555$; the value, timothy, $\$ \mathrm{r} 88,082,895$, timothy and clover, $\$ 257,280,330$. This is far above the amount for any other hay crop. The corresponding figures for alfalfa, the greatest of the leguminous crops are: acreage, 4,707,146; production, II $859,88 \mathrm{I}$; value, $\$ 93,103,998$. The states leading in the production of timothy and of timothy and clover are given in Table IV (page 7). 


\section{Timothy as a Meadow Grass}

Timothy is a short-lived perennial and is not well adapted to permanent meadow. The hay crop decreases markedly after the first two or three years. For best results, therefore, a meadow should be kept in timothy for only two or three years and then plowed up and used for some other purpose. Usually the plan is to mow for hay the first two years and continue for pasture the third year. It is a common practice over much of the humid region to grow timothy with clover. Hay grown for the market is usually made from timothy grown alone, as pure timothy hay is demanded in most markets and brings a higher price than mixed hay, and for horses is more suitable. For consumption on the farm timothy and clover is desirable as it is more nutritious, though not so well adapted to horses.

Timothy may be sown in fall or spring according to circumstances. When the conditions are favorable, timothy alone or timothy and clover mixed should be sown in the fall, that is in late August or early September. The plants should be well started by the end of the growing season and produce a full crop the following year. In this way the crop is produced with the least loss of time. If the seed is sown in the spring, a crop will be produced the first year but not a full crop. Furthermore, weeds interfere with a spring-sown crop much more than with a fall-sown one. Therefore, there is a greater return from the land if a summer crop is grown which can be removed in time for the fall sowing of timothy. It is a common practice in much of the timo- 
thy region to sow grain with timothy in the fall. In this way a grain crop is produced the following year and a full crop of timothy the third year. Apparently the crop of grain is a clear gain. This is so only under poor methods of culture. If the land is in good condition, and the crops are treated properly, a greater return is received by sowing the grain alone, then after the crop is removed, preparing the land for timothy to be sown in the fall. The increase in the crop of grain should pay for the preparation of the land for the timothy. If the grain is sown too thickly with timothy, the latter suffers and will not produce a full crop the following year. Some growers sow clover in the spring upon the timothy sown the preceding fall. This is done especially when the timothy has been sown with grain.

In preparing the seed bed for timothy, it must be remembered that the seed is very small and should be covered lightly: It is therefore necessary to exercise care that the soil be placed in fine tilth. The harrowing should be such as to cover the seed not deeper than about half an inch.

On land not perfectly adapted to timothy, a little redtop may be added as a filler. This will increase the yield. Spots that are too wet for timothy will produce redtop. This is not advisable if the timothy is grown for sale as the admixture of redtop reduces its price. Timothy should be sown with a seeding machine, such as a wheelbarrow seeder. A drill places the seed too deep. If sown with grain a grain drill can be used with a special timothy attachment. The amount of seed sown per acre depends upon the condition of the soil. It also 
depends upon the purity of the seed, but fortunately for the grower, timothy seed is usually of a fairly high grade of purity and viability. It is customary to use I 2 to I 8 pounds per acre. If clover is used, the amount of seed is about 8 pounds per acre. Timothy seed weighs 45 pounds per bushel.

\section{DESCRIPTION}

A perennial grass usually 2 to 3 feet tall, smooth, from a somewhat bulbous base, growing in small tufts. Leaves flat, in the larger plants as much as a foot long. Panicle or head a dense cylindrical spike 2 to 5 inches long. Anthers bluish.

Details of the Spikelet.-Spikelet strongly flattened, I-flowered, about $3 \mathrm{~mm}$. long; glumes equal,oblong, longciliate on the keel, rounded to a short awn I to $2 \mathrm{~mm}$.* long; lemma and palea about equal, thin and pale, about half as long as the glumes. The seed of commerce is the caryopsis, mostly enclosed in its lemma and palea.

Common Names.-Timothy is the

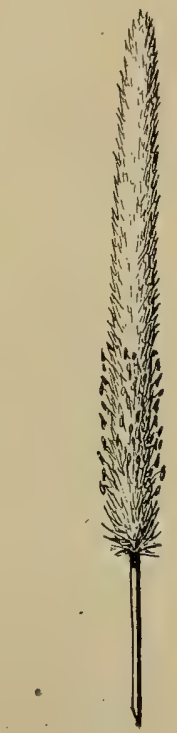

4. Timothy. A single head, the lower part in flower, the stamens protruding.

name most widely used for this grass, this name coming from that of Timothy Hanson who is said to have introduced it into this country. In some localities this species is known as Herd's grass, a name which is also used for redtop.

*A millimeter (mm.) is about $\mathrm{r} / 25$ of an inch. 
Botanical Name.-Phleum pratense L. The genus Phleum includes several species of the Old World that are of no importance agriculturally. One species, mountain timothy ( $P$. alpinum L.), is found in mountain regions of both Europe and North America. This is of some importance as a forage grass in mountain meadows. Phleum is an ancient Greek name for a kind of reed but was applied by Linnaeus to the genus of grasses described above. The specific name pratense means growing in meadows.

\section{BLUEGRASS}

Bluegrass is the most important pasture grass in America. It does not thrive throughout the United States, however, but only in those regions which furnish the proper conditions. These conditions are a cool, moist climate and a fertile soil rich in lime. The area adapted to bluegrass is, in general, the humid region, that is, the northeastern states south to Virginia and west to eastern Kansas, extending south in the mountains to northern Alabama, the northern Pacific Coast from Puget Sound to California, and also many isolated areas in the western mountains. The limitations mentioned above are determined mainly by climatic conditions. Bluegrass requires the moisture which is furnished in the humid region by the summer rainfall. Its limits of cultivation can be extended by the use of irrigation, but even with artificial water supply, it will not thrive in the southern states and in the arid region. Even in the humid region, it may suffer from drouth in summer. In eastern Kansas and other localities where summer drouths are of frequent occurrence, bluegrass languishes 
during the summer months but revives rapidly during the spring and fall.

Within the climatic area adapted to its growth, bluegrass may fail because of the sterility of the soil or because of the lack of lime. Sterility of the soil may be corrected by the use of fertilizers or by thorough cultivation, but often these methods are not practicable. If it is desirable to utilize sterile hills for pasture, it may be advisable to use other grasses than bluegrass for this purpose.

As has been said, soils lacking in lime, the so-called acid soils, are not well suited to bluegrass. Such soil is found especially in the New England states and on the Atlantic Coastal Plain. Acid soils are found less frequently in the Middle States. Recently-drained swamp land is usually unsuited to bluegrass without special treatment. Acid soils may be rendered suitable by the addition of lime or land plaster if the lack of lime is the only unfavorable condition. In the lime-poor region of the Atlantic Coast it may be more economical to use some grass like redtop that thrives on such soil, than it would be to resort to liming.

\section{Bluegrass for Pasture}

In the humid region, bluegrass is the best grass for permanent pasture. It does not fit well, however, into a rotation where only one, two, or even three years are given to pasture. For one or two crop years, larger returns are given by other grasses such as timothy or orchard grass. In regions where bluegrass abounds it comes in spontaneously and occupies grassland suited 
to its growth. If the species is not found in the locality, it will be necessary to sow the seed. The treatment is the same as that for other pasture and meadow grasses, the seed being sown on well-prepared land in spring or early autumn. In regions subject to summer drouths, bluegrass makes a favorable growth in spring and fall but is dormant during the dry season.

\section{BLUEGRASS FOR LAWNS}

Bluegrass is the most important lawn grass over the area in which it excels as a pasture grass. Its use as a lawn grass, however, is practicable where its use as a pasture grass may be impracticable, because it is easier to supply favorable conditions on small areas. The conditions necessary are sufficient moisture and a soil fertile and rich in lime. It is therefore possible to grow bluegrass for lawns far outside of the range indicated for pasture. However it will not thrive in the Southern States nor in arid regions of the southwest. In regions where favorable conditions are not supplied by nature, it is always worth considering whether there may not be some other grass that will be adapted to the conditions as found. If the soil is lacking in lime, it may be better to use carpet bent than to lime the soil for bluegrass. In the south, there are grasses, such as Bermuda grass and carpet grass suited to the conditions found there. The conditions necessary for the growth of bluegrass as indicated above, water, fertility, and lime, may be supplied when lacking, by sprinkling, by the use of fertilizers, and by liming. 


\section{Making a Bluegrass LaWN}

A lawn may be made by transplanting turf or by seeding. In either case the preparation of the soil is the same. The best soil is a rich, well-drained loam such as would be considered good soil for the growing of corn, wheat or other field crops. This soil should be prepared by plowing and harrowing to put it in fine tilth. The turf should be cut from a pure stand of old bluegrass sod, transferred to the prepared soil as soon as possible to prevent the drying out of the roots, laid closely and evenly and tramped or rolled firmly in place. The sod can be cut in squares and placed in piles or cut in strips and rolled up, these methods tending to prevent the exposure of the roots to the drying influence of the air. After the turf is placed, the lawn should be thoroughly wet down. If all the conditions are favorable, this is the best and quickest way to get a good lawn. In practice it is not often that all these conditions are fulfilled. It is difficult to obtain a pure sod of bluegrass. If the soil is contaminated by weeds, these become troublesome and are not easily removed. If the sod contains few weeds but is a mixture of grasses, the resulting lawn will lack uniformity in color and texture. To those who are particular in regard to the appearance of a lawn, these are serious objections. Because pure or unmixed sod of bluegrass is usually not available, turfing cannot be relied upon to produce the best lawn, and one must resort to seeding.

If the soil is not fertile it must be put in proper condition by the addition of fertilizer. Good well-rotted barn- 
yard manure free from weed seed is the best fertilizer but is not always obtainable. This should be well incorporated with the soil. In the absence of barnyard manure, artificial fertilizer may be used. Those preparing a lawn are not likely to know what ingredients are lacking in the soil, hence it is best to use a complete fertilizer. The amount necessary depends upon the condition of the soil. Ordinarily one may count on using 300 to 400 pounds per acre or approximately 2 to 3 pounds per square rod. If the soil is lacking in lime, this ingredient should be added in the form of slaked lime, land plaster or gypsum at the rate of 5 to io pounds per square rod.

Seeding should be done early in the spring. It is important that the best seed be used. On account of the method of harvesting, the viability of bluegrass seed is likely to be rather low in the best quality; in a poor quality the seed may be almost worthless. The seed is sown at the rate of about 60 or even Ioo pounds per acre or about $I / 2$ pound per square rod. It is a favorite practice in some localities to sow the seed upon the late snow and allow it to sink into the soil as the snow melts. Some authorities recommend sowing the seed with some grain such as oats or rye. The grain germinates first and acts as a nurse crop. Later the grain is mowed off. Usually, however, better results are obtained by sowing the grass seed alone.

The directions above given apply to the production of a bluegrass lawn of uniform texture and color. If uniformity in these respects is not required, and the condition of fertility and tilth have not been fully met, it will 
be advisable to sow a mixture of grasses, such as bluegrass, perennial and Italian rye grass, carpet bent, and some of the small fescue grasses. The result will lack in uniformity but there may be a gain in vigor and continuity of soil cover.

In either turfing or seeding, the lawn should be watered if the rainfall is not sufficient in amount or frequency. It is best to wet the soil thoroughly at intervals of a few days, rather than to sprinkle lightly every day. Watering is most efficient after the heat of the day has past, as the application of water during the middle of the day may result in scalding the foliage.

The practice of attempting to establish a lawn upon soil left from the excavation of a cellar or upon the refuse left from building operations cannot be too strongly condemned. If the lawn is started by seeding on such a foundation the result is likely to be a vigorous crop of weeds. If turfing is resorted to, the grass will decline as soon as the nourishment in the sod is exhausted. Sod used by builders and contracters is often obtained from a nearby vacant lot and contains in most cases many pestiferous weeds. Under such conditions no amount of faithful watering can correct the original evil. If there is a poor stand, it is best to plow up the ground and begin again. If the stand is good, the condition of the lawn can be maintained or even gradually improved by mowing, rolling and watering when water is needed.

If a lawn is to be established on land about a dwelling and such land is covered by the clay from the excavation and by refuse from the building operations, it will be necessary to remove a portion of this sterile soil and fill 
in with good soil to the depth of one foot or, still better, two feet. This is necessary for good results whether the lawn is to be made by turfing or by sowing seed. If turfing is the method employed and the supply of good turf is limited, good results may be obtained by cutting the turf into small pieces and planting in the prepared soil at intervals of several inches. The pieces should be pressed firmly into the soil. Under favorable conditions, the grass will spread and cover the surface in a few weeks. Turfing with a continuous cover may be done at any time during the growirg season. Turfing with cut pieces should be done not later than early fall in order to allow sufficient time before winter, to fill in the space between the pieces. Seeding should be done early in the spring or early in the fall. The latter is recommended for Maryland and vicinity.

To produce a soft, even, elastic surface, a lawn should be frequently mowed. Rolling is also a great aid in this respect. If the mowing has been neglected and a tall growth of grass has resulted, this should not be cut very close the first time as the roots might be exposed to the influence of the hot sun. It is best to cease mowing in the fall before the winter's cold sets in, so that the roots may be protected by a moderate growth of foliage.

The lawn should be top-dressed with well rotted manure in the winter or early spring. This treatment should be given each year or at longer intervals according to the requirements of the soil. In lime-poor soils, there should also be a dressing of lime at intervals, this to be applied in the winter. It is an excellent practice to graze sheep upon large lawns. This is good for the lawn 
and good for the sheep. The grazing, tramping and the deposit of manure are all a benefit to the lawn.

If barnyard manure is not available, artificial fertilizer should be added when necessary to keep up the fertility of the soil. Bone meal, woodashes, and various prepared complete fertilizers can be used.

\section{LAWN WEEDS}

Under favorable conditions of soil, climate and treatment a bluegrass lawn should hold its own against weeds. But if conditions are not of the best, a lawn becomes contaminated with weeds. These impair the appearance of the lawn in two ways. The uniformity of texture and color is destroyed, and, in the case of annual weeds that die off in summer and fall, unsightly bare spots are developed. Certain annual weeds may gain a foothold in small open spaces between the tufts of bluegrass and gradually crowd out the latter. These interlopers are not noticed at first but their presence is evident later, especially in the latter part of the season when they turn brown and finally shrivel and die. Weeds should be removed as thoroughly as possible or they will gain the upper hand. The commonest of the annual weeds in the region where bluegrass is grown are crab grass and annual bluegrass. Crab grass soon makes its presence known by the purplish color of the foliage. Annual bluegrass is more deceiving because in its early stages it is a pleasing green but lighter in color than the bluegrass.

Perennial weeds are more difficult to eradicate. Some of the troublesome perennials in the region under con- 
sideration are dandelion, wild onion and plantain. If weeds become numerous, it is best to plow up the lawn and begin over. The deficiencies in the soil can then be remedied and the weeds prevented from getting a start.

\section{Bluegrass Seed}

Commercial bluegrass seed comes mostly from a rather limited area in Kentucky. The chief producing counties are Bourbon, Fayette and Clark. These counties are in the famous bluegrass region south of Cincinnati. Smaller quantities are harvested in other parts of the state especially in the counties to the west of those mentioned. Another but less important area is found in northern Missouri and southern Iowa.

The seed is harvested by stripping the heads, a good yield being 20 to 25 bushels per acre. Fields of bluegrass can be grazed by cattle up to about two weeks of harvest with little detriment to the seed crop, but horses reduce the production as they eat the heads.

The seed in the regions mentioned is harvested mostly in early June. On the larger farms, horse-drawn strippers are used which pull the spikelets from the stalks. On small fields hand strippers are used. The seed, which contains much chaff and pieces of leaves and stems, is piled in ricks either in the open or in sheds. The ricks are turned and stirred at frequent intervals till dry. Much care must be exercised to prevent the seed from heating, as this destroys its vitality if the process is allowed to go far. The cured seed is then sent to the cleaner. The cleaning machines remove the wool from the florets and separate the seed from the chaff. 
The export trade demands that fancy seed should weigh 22 pounds per bushel. The seed on the domestic market is usually lighter than this and correspondingly poor.

\section{Bluegrass as a Weed}

In the alfalfa regions of the west, bluegrass often becomes a troublesome weed in alfalfa fields. It thrives under irrigation and pushes in wherever the alfalfa is scanty, gradually crowding out the latter. The bluegrass does not grow tall enough to replace the alfalfa in the yield and there is a distinct loss. There is no remedy for a badly infested alfalfa field but to plow it up and start anew.

\section{DESCRIPTION}

A perennial grass, usually i to 2 feet tall, but under favorable conditions 3 or even 4 feet tall, producing slender creeping rootstocks sending up new shoots at intervals, the mass of rootstocks finally forming a firm sod. The stems erect, usually somewhat tufted, smooth, round or very slightly flattened (this noticeable by rolling between thumb and finger). The leaves mostly at the base of the stem. Sheaths smooth, sometimes somewhat keeled or angled along the back, the lower short, but the uppermost long. Ligule short and very blunt, thin, about I mm. long, that of the sterile shoots shorter and that of the uppermost stem leaf longer. Blades narrow, those of the basal cluster long and slender, several inches or even a foot long, usually not over $4 \mathrm{~mm}$. wide, flat of folded, a cross section thus $\mathrm{V}$-shaped, the tip suddenly narrowed into a boat-shaped point, the 
uppermost blade $\mathrm{I}$ to 3 inches long, appressed to the stem, slightly roughened on the edges. Inflorescence a pyramidal panicle 3 to 6 inches long, the branches loosely

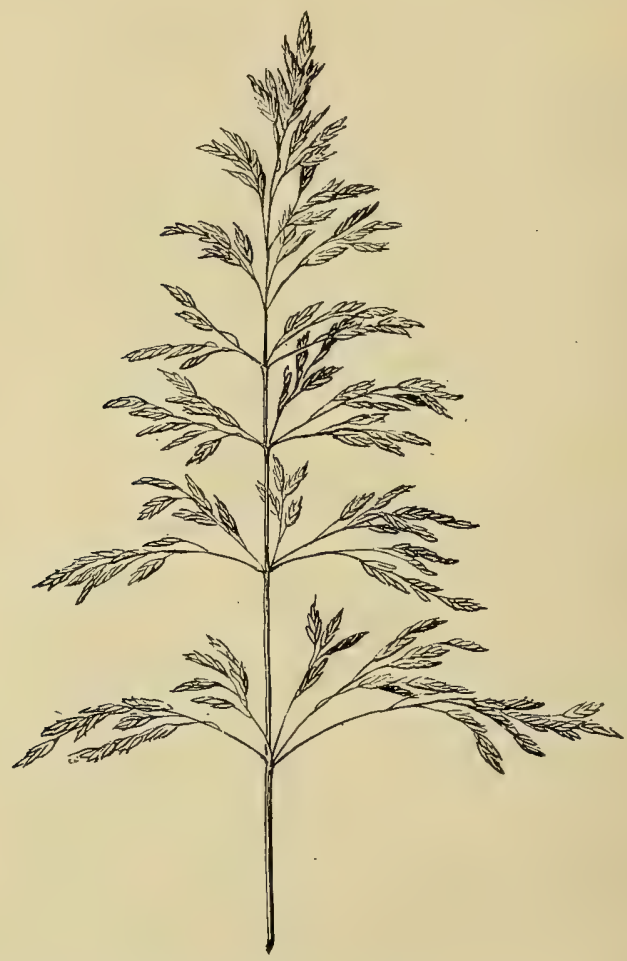

5. Kentucky Bluegrass. A single head or panicle.

spreading, the lower in a whorl of usually 5 , the others clustered or scattered, all of them slender and somewhat flexuous, roughened, naked at base, the five in the lower whorl of unequal length, one being long, two shorter and 
two still shorter. Spikelets clustered toward the end and upper half of the branches.

The color of the foliage is dark green rather than blue green as the name would indicate. In moist, shady places the leaves often become splotched with a white powder due to the presence of a fungus called powdery mildew.

The flowering period is May to June according to the latitude.

Details of the Spikelet.*-Spikelet ovate or lanceolate, flattened, 3 to 5 -flowered, sometimes with more flowers, 4 to $6 \mathrm{~mm}$. long. Glumes acute, smooth, about half as long as the spikelet, the first I-nerved, the second 3nerved. At maturity the florets separate from each other and from the glumes. Florets acute, 5-nerved, the apex thin and papery, often purple-tinged, the midnerve and outer pair of nerves minutely hairy, the base of the floret with a tuft of fine cobwebby hairs. These florets form what is known commercially as the seed, though as in most grasses the real seed is inside of these.

Common Names.-Bluegrass, in order to distinguish it from other species of the genus, that is, from other bluegrasses, is called Kentucky bluegrass, this name having come into use because of the famous bluegrass pastures of Kentucky. In the northern portion of its range this grass is usually known as June grass. Another name sometimes heard or sometimes seen in books is spear grass. In England, it usually goes under the scarcely distinctive name of meadow grass.

* See page 49. 
Botanical Name.-Poa pratensis L. The genus Poa includes the species of bluegrass of which there are about Ioo, found in all the cooler parts of the world. Only a few of these have been brought into cultivation, the species under consideration being by far the most important. Poa is a word used by the ancient Greeks for grass in general, but Linnaeus adopted the name for the genus as now understood. The term pratensis means growing in meadows.

\section{BERMUDA GRASS}

Bermuda grass is the most important pasture grass of the Southern States. It is a native of the warmer parts of the Eastern Hemisphere, but was early introduced into America and is now widely distributed in tropical America and extends well northward into the warmer temperate zone, being hardy as far north as Washington, D. C., and southern Kansas. Bermuda grass thrives on the open uplands and is the only grass now in use that gives summer pasturage in the region mentioned. In moist valleys or in the low land along the coast, other grasses thrive and dispute its dominance. Except on alluvial bottom land it does not grow rank enough for hay and in such locations other grasses may give better results. Except in the extreme South, Bermuda at least partially suspends growth during the winter months. Hence it is supplemented by those grasses that furnish winter pasturage. It forms a close sod by means of its rootstocks and stolons, a habit which especially adapts it to lawns. Throughout the Southern States it is the only grass that can be recommended for lawns, except in 
alluvial land along the Coast where carpet grass and St. Augustine grass are used.

Bermuda grass, because of its abundant creeping rootstocks, is very aggressive. It freely occupies open ground where it forms strong vigorous rootstocks as thick as a pencil, that penetrate in all directions. For

F this reason, it is difficult to eradicate and becomes a pestiferous weed. This form is often called wire grass and it is sometimes difficult to convince farmers and planters that this coarse aggressive weed is the same as the fine-leaved Bermuda. But the two forms are the same species, the difference in aspect being due to the different conditions under which they grow or to different strains of the species.

Bermuda does not grow well with other grasses, but may be combined with Japan clover, bur clover, black medick, or sweet clover.

\section{Bermuda as a Pasture Grass}

Bermuda pasture may be established by sowing the seed or by planting cuttings. For seeding, it is necessary to prepare the soil carefully as the seed is very small. The seed is sown in early spring at the rate of about 6 to 8 pounds per acre and rolled in, unless sown just before a rain when the rolling may be omitted. In the Gulf States it is recommended that Bermuda be combined with bur clover or with Japan clover. The pasturage is more nutritious and the grazing may be extended through the entire season. The seed upon the market has been mostly imported from Australia, but much is now obtained from southern California and Arizona. 
Bermuda pasture, when not combined with other plants, should furnish grazing from May to November. A Bermuda pasture may become sod bound in a few years, ' in which case it is best to plow it up and harrow it in the spring. The rootstocks make a new start and soon occupy the soil. Under favorable conditions, an acre of Bermuda pasture should support two cows for eight months.

As the seed of Bermuda is high priced, pastures are frequently started from cuttings. The cuttings are obtained by chopping sod into small pieces. These pieces may be planted in furrows, the soil being turned back over them, not covering them more than 2 inches, or the pieces may be forced into soft soil by stepping on them. The pieces may be planted two feet apart each way, so easily can Bermuda be started that the distance apart of the planting is not very material. If large quantities of cuttings are wanted, a field of the grass may be plowed and the roots harrowed into windrows for use. A carelessly cultivated corn or cotton field, if infested with Bermuda, may be so completely filled in a season that it is ready for pasture the following year.

\section{BERMUDA FOR LAWNS}

Bermuda has all the desirable qualities of a lawn grass except that of holding its color during the winter. The color in summer is a light green which, to some, is not so pleasing as the dark green of bluegrass. But at the approach of cold weather it turns brown or tawny and does not become green again until rather late in the spring. Nevertheless, it is the best lawn grass, for the 
South, of any now in cultivation, except on mucky soil along the coast where carpet grass and St. Augustine grass may be used. Both these grasses are much coarser than Bermuda and do not produce a surface so pleasing in texture.

St. Lucie grass is a form of Bermuda especially adapted for lawns. It is somewhat finer in texture and the propagating stems are more upon the surface. This form is much used in Florida. Giant Bermuda is a rankgrowing form producing stems two feet or more in height, and is adapted to rich moist soils.

A lawn may be started by transplanting sod or by sowing the seed. If sod is used, care should be taken to select a pure stand of a fine-textured. strain. If seed is used, the soil should be carefully prepared, pulverized and leveled. To insure an even stand, the seed should be sown evenly and rather thickly. Usually under favorable conditions, the Bermuda will soon completely occupy the soil. If necessary, the lawn should be watered and the weeds removed. Like all lawns it is improved by mowing and rolling.

\section{Methods of ERAdication}

The ease with which Bermuda becomes established, and the aggressiveness with which it spreads, render it a troublesome weed in cultivated soil, and make it difficult to eradicate when it has once occupied the soil. Methods of eradication depend upon the fact that it does not thrive in the shade. Therefore the easiest and quickest method is to smother it with some quick-growing crop. A very good way to convert Bermuda pasture or meadow 
into land fit for a cultivated crop such as corn or cotton,

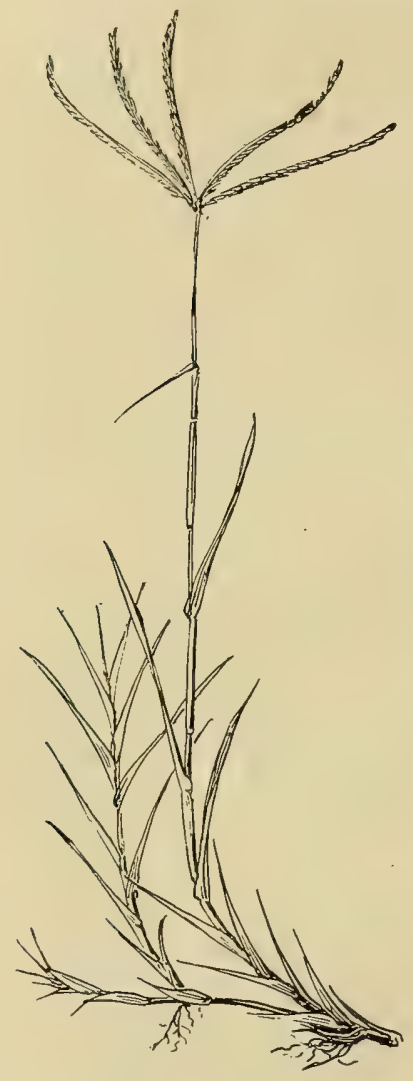

6. Bermuda Grass. A plant showing the creeping base, and a fertile stem with a cluster of five flower spikes. is to plow in the fall and sow thickly to grain. After the grain is harvested, plow the land immediately and plant thickly to cowpeas. If the cowpeas are planted in rows and cultivated till the vines meet, the ground will be shaded and the Bermuda smothered out. Usually one season of this treatment is sufficient if the grain and peas have made a good growth. Some roots of Bermuda may remain alive and the field will in time become infested with Bermuda and can then be used for pasture. In this way there is a favorable rotation of crops.

\section{DESCRIPTION}

A low perennial, extensively spreading by creeping stems, those below ground called rootstocks, those above ground called stolons; flowering stems in open ground only a few inches high 
but in alluvial soil or in the shade, as much as 2 feet tall, erect or decumbent at base; sheaths smooth, compressed, keeled, bearing a tuft of hairs on each side at the summit; blades flat, $\mathbf{I} / 2$ to 2 inches long, or on sterile shoots, longer, somewhat roughened, especially on the margin, sharp-pointed; ligule a very short membrane, hairy on the edge; inflorescence consisting of 3 to 6 slender spikes, I or 2 inches long, all closely clustered at the summit of the stems, pubescent or fuzzy at the base; axis of the spike $\mathrm{I} / 3$ to $\mathrm{I} / 2 \mathrm{~mm}$. wide, the spikelets closely arranged along one side.

Details of the Spikelet.-Spikelets I-flowered, compressed, about $2 \mathrm{~mm}$. long, tawny green or purplish; glumes two, narrow, pointed, scabrous on the keel, shorter than the spikelet; lemma boat-shaped, pubescent on the margins and of ten on the keel.

Common Names.-Bermuda grass is the most widely used name in this country. In the southwestern states, it is known as devil grass, and the weedy form in the southern states is called wire grass, or occasionally scutch grass. It was probably introduced from the Bermuda Islands, where, however it is not native. Its native country is the Mediterranean region and southern Asia. In the West Indies, at least in the English islands, it is usually known as Bahama grass. In Cuba and other Spanish countries it is known as grama, which means grass, or hierba fina, which means fine grass, hierba del prado, which means park grass and pato de gallina, which means chicken-foot. The German and French names for the grass mean dog's-tooth. In India, it is called sacred grass. In Australia, it is called couch or 
Indian couch. In the Hawaiian Islands, it is called manienie (ma-ne-a-ne-a).

Botanical Name.-Capriola Dactylon (L.) Kuntze; Cynodon Dactylon Pers.; Panicum Dactylon L. There is but one common species of the genus and this is widely distributed in the warm regions of both hemispheres. The name Capriola comes from a Latin word for goat, probably given because goats feed on the grass. The specific name Dactylon is a reference to the inflorescence, from the Greek word for finger, the spikes spreading from one point like the fingers on the hand. The other generic name, Cynodon, in common use, means dog-tooth, given probably because of the old pointed sheaths on the stolons and rootstocks. The giant Bermuda is Capriola Dactylon var. maritima. 


\section{CHAPTER VII}

\section{OTHER IMPORTANT FORAGE GRASSES}

IN addition to the grasses already considered, there are several that are important in certain areas and for certain purposes, though when compared with the three leading species they are decidedly secondary, both as to quantity and value.

\section{REDTOP}

Next to timothy, redtop is probably the most important meadow grass in the humid region, that is, in broad terms, the timothy region. It is used also for pasture, for which purpose it ranks next to bluegrass. Redtop does not compete with timothy or with bluegrass but supplements them, for it thrives in soils too moist for timothy or in lime-poor soils where bluegrass is not at its best. Hence it is that redtop is used alone or in mixtures for moist soil, or, on the other hand, for comparatively dry but sterile soil, or for the so-called acid soils that are poor in lime. Redtop is grown especially in New England, the North Atlantic States and in moist or lime-poor soils elsewhere, especially in Missouri and southern Illinois. It becomes more important than timothy in the belt just south of the timothy region from Arkansas and northern Louisiana, through northern Mississippi and northern Alabama to North Carolina. In this belt it is frequently called Herd's grass. 


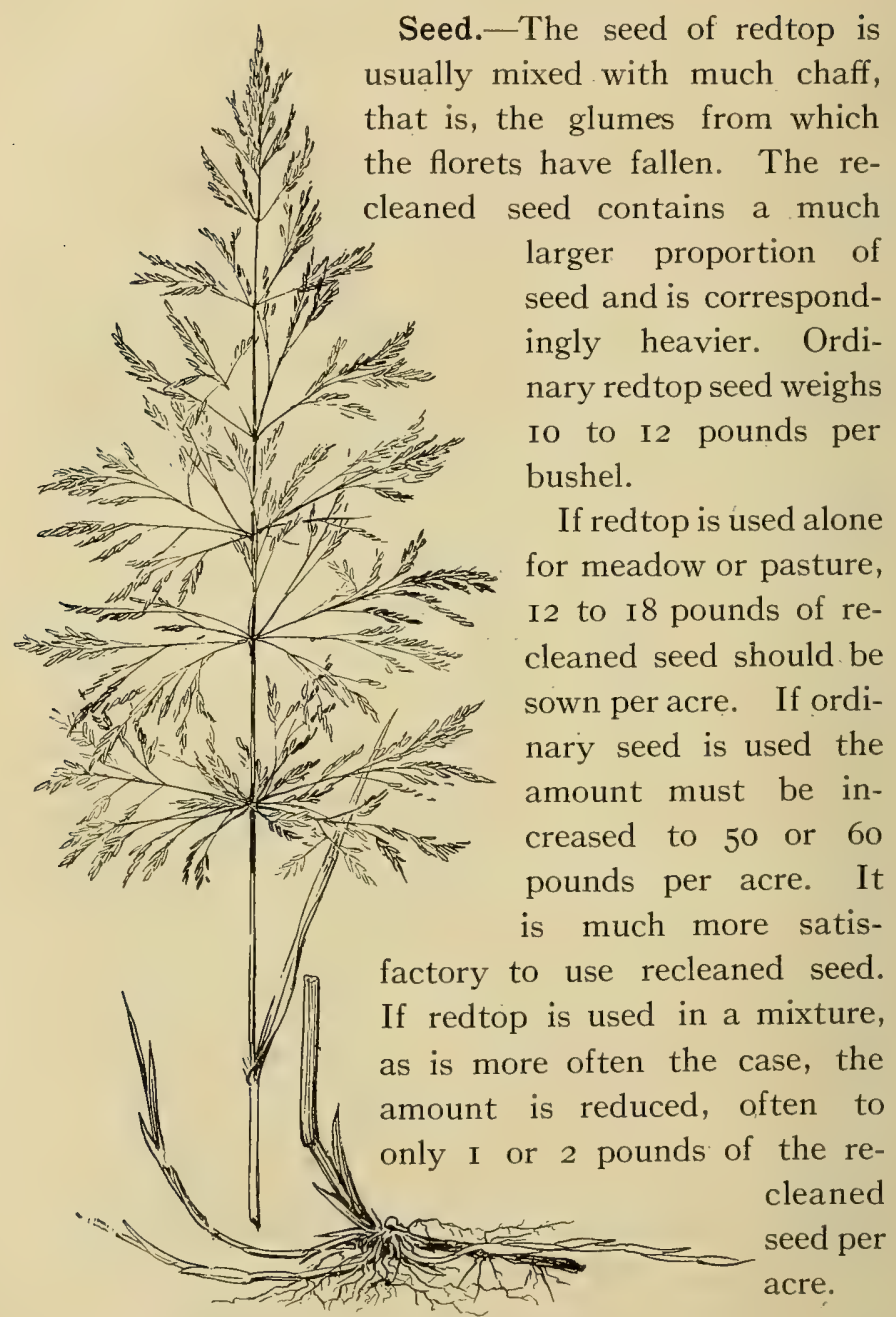

7. Redtop. A single head or panicle, and a base showing the creeping rootstocks by which the grass spreads. 
Description.-An erect perennial, I to 3 feet tall, or sometimes taller in favorable localities, the base often decumbent, producing creeping rootstocks; sheaths smooth; blades flat, rough on both surfaces, mostly 4 to 8 inches long, narrowed into a long sharp point, the ligule thin, pointed, as much as $6 \mathrm{~mm}$. long ( $\mathrm{I} / 4$ inch); panicle usually 4 to 8 inches long, broadest near the bottom and narrowing toward the top, pale or often purplish or brownish, the branches in whorls, horizontally spreading or somewhat ascending, some of the branches naked below, others shorter and flower-bearing mostly to the base, the upper branches scattered and more ascending, all rough to the touch. After flowering the panicle may partially close.

Details of the Spikelet.-Spikelets one-flowered, small, only 2 to $3 \mathrm{~mm}$. long ( $2 / 25$ to $3 / 25$ inch); glumes 2 , about equal, gradually narrowed to a sharp point, roughened on the keel; lemma a little shorter than the glumes, thin and transparent, rather blunt; palea half to twothirds as long as the lemma and like it in texture.

Common Names.-The usual name is redtop but it is called in some localities, especially in Pennsylvania and the Southern States, Herd's grass. The latter name is sometimes applied to timothy and should, for the sake of precision, be discarded. The name redtop is characteristic because in the cultivated form, the panicle is usually purplish or brownish at flowering time though it may become pale or faded at maturity.

Botanical Name.-Agrostis palustris Huds. The genus Agrostis includes a large number of species (about IOo) found in temperate and cool regions all over the 
world. There are 25 species in the United States especially in our western mountains. Most of the species are good forage grasses and constitute a considerable portion of the native forage of mountain meadows. The name Agrostis is derived from a Greek word meaning field and was used by the Greeks for a kind of grass. Linnaeus applied the name to the genus above mentioned. The specific name palustris means swampy, referring to the fact that it grows in moist soil. Another name that has been commonly applied to redtop is Agrostis alba.

\section{ORCHARD GRASS}

Compared with timothy, orchard grass is unimportant, but among the grasses of minor importance it stands in the front rank. It is used for both hay and pasture in the humid region, especially from Virginia and Kentucky to northern Alabama. Orchard grass has many good qualities, among which are yield, palatability, early starting of growth in the spring, and ability to remain green during hot summers and well into the fall. Its chief drawback is the habit of growing in tussocks which interferes with its use as a meadow grass. The high cost of the seed also militates against its use, though the cost would decrease if the demand called for a greater supply, because good seed is easily produced. Timothy has such a dominating position in the hay markets of the country that orchard grass and other good grasses cannot compete with it, a condition which discourages its production for hay to be sold. The quality of orchard grass suffers more than does that of timothy by remaining after flowering before being cut. For this reason, orchard 
grass has not been grown much where timothy is at its best, but finds favor along the southern border of the timothy region where the summers are long and dry. It withstands drouth rather better than does timothy and hence can be used somewhat west of the region where timothy thrives. When sown alone, 20 to 25 pounds of good seed per acre should be used. By mixing orchard grass with some other grass, such as meadow fescue, a smoother surface is produced than by using the former alone.

Orchard grass was brought into cultivation about the middle of the eighteenth century. It is one of the important meadow grasses of Europe. Beal states that it did not attract much attention in England until sent back there from Virginia in 1764 .

The seed of orchard grass of American origin is mostly grown in the vicinity of Louisville, Kentucky. Much seed is imported from New Zealand.

Description.-An erect perennial, 2 to 4 feet, growing in tussocks, without rootstocks; sheaths flattened and somewhat keeled, smooth or roughened, closed part way or nearly all the way, the ligule prominent, thin and papery, the uppermost about one-third of an inch long; blades flat, about one-third of an inch wide, rough on both surfaces, tapering into a slender point; panicle 3 to 6 inches long, the few branches spreading at flowering time, afterwards closed, singly disposed, naked below, bearing towards the ends a few one-sided clusters of spikelets, the clusters about $\mathrm{I} / 2$ inch wide.

Details of the Spikelet.-Spikelet 3 or 4 -flowered, compressed, about one-third inch long; first glume 
I-nerved, acute, the second 3 -nerved and acuminate, a line of minute bristles along the keel; lemmas 5-nerved, bristly along the keel, extending into a short awn at the apex.

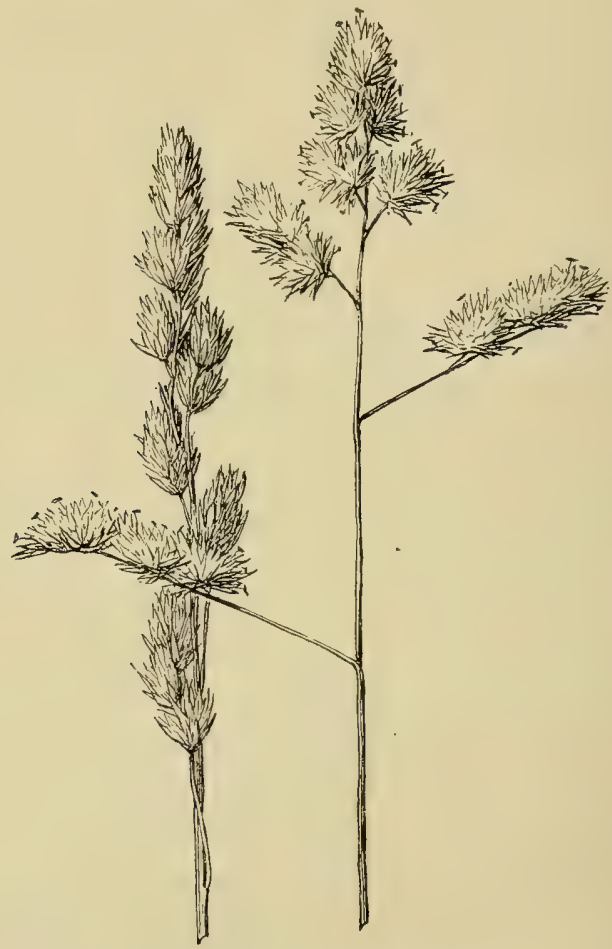

8. Orchard Grass. Two heads or panicles, one in flower, the branches spreading, the other in fruit or seed, showing how the branches close up after flowering.

Common Names. - In this country this grass is uniformly known as orchard grass, probably because in the 
early days it was sown in orchards. In England, it is called cock's-foot, in allusion to the spreading branches of the inflorescence when in flower.

Botanical Name.-Dactylis glomerata L. The generic name Dactylis is derived from a Greek word meaning finger in allusion to the finger-like branches of the inflorescence. The specific name glomerata, clustered, refers to the clusters of spikelets at the ends of the branches.

\section{MEADOW FESCUE}

Like orchard grass, meadow fescue holds a secondary though not unimportant place in American agriculture. It has many good qualities but has not been able to compete with timothy. The chief reason for this is probably the relatively high cost and poor quality of the seed. Furthermore, the yield is usually not so high as that of timothy. Meadow fescue however is a nutritious and palatable grass and makes an excellent quality of hay. It is grown for both hay and pasture throughout the timothy region but nowhere abundantly. It has become a rather important grass in the eastern portion of the Great Plains region, especially in eastern Kansas. Meadow fescue is to be recommended in combination with other grasses, especially where used for pasture. In eastern Kansas it is used to advantage in combination with orchard grass. For meadow, it makes a good filler with orchard grass, filling in the spaces between the tussocks of the latter, thus giving a better basis for a mowing machine. In the region mentioned, the combination has the advantage over timothy of being more drouth resistant and can therefore be used somewhat 
west of the area best suited to timothy. Meadow fescue

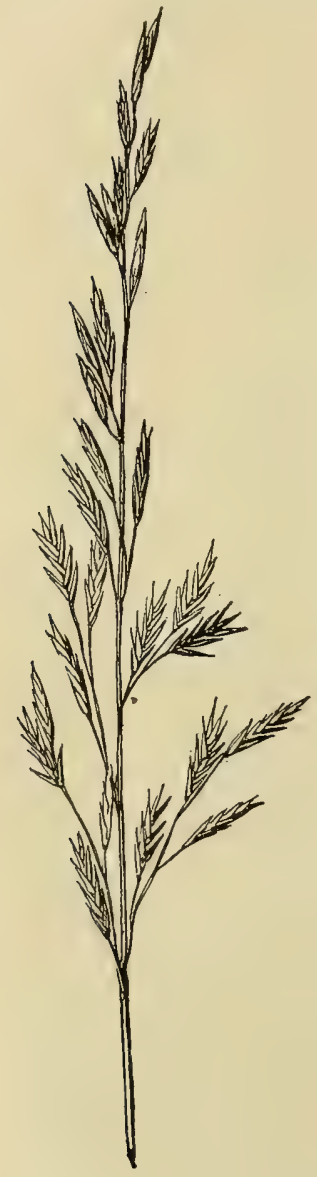

9. Meadow Fescue. A single head or panicle. is being used to some extent also in the Pacific Northwest.

Most of the seed grown in this country is produced in southeastern Kansas.

Description.-A rather tall perennial, sometimes with short rootstocks; stems erect, I to 4 feet tall, usually 2 to 3 feet; sheaths smooth; blades flat, I/12 to I/5 inch wide, rough on the upper surface; panicle erect, nodding at the apex, narrow but spreading in flower, 4 to 8 inches long, the branches mostly singly disposed, bearing few rather large spikelets.

Details of the Spikelet.-Spikelets several-flowered, oblong, about $\mathrm{I} / 2$ inch long, smooth and green, the florets usually 7 or 8 ; glumes lanceolate, somewhat unequal, about half as long as the first floret; lemmas rounded on the back, finely nerved, scarious at the acute apex.

Common Names. - M e a d ow fescue is the recognized name for the species. The taller form, as described under the paragraph on botanical names, is called tall fescue. In some parts of 
the country, especially in eastern Kansas, the species is known as English bluegrass. This is an unfortunate application of the name as it is more properly applied to Poa compressa, and because the species in question does not belong to the bluegrass group.

Botanical Name.-Festuca elatior L. Festuca is an old Latin name applied to a kind of grass. The specific name, meaning taller, refers to its comparative height, the plant being taller than the other species described at the same time. The species has also been known as Festuca pratensis Huds. The two names, however, apply to the same form. As mentioned elsewhere, there are two forms of the species, one called meadow fescue as already described. The other is called tall fescue. This second form is more robust and has a larger, more open panicle. Some botanists have applied the name Festuca pratensis to the first and $F$. pratensis var. elatior, or $F$. elatior to the second. The original descriptions of $F$. elatior and $F$. pratensis apply to the same form, the taller form not having received a distinct botanical name. The differences between the forms are agricultural rather than botanical.

\section{JOHNSON GRASS}

Johnson grass is one of the most important haygrasses for the Southern States. It is palatable, nutritious, a vigorous grower and yields large crops. It thrives best on alluvial bottoms and is especially adapted to the black prairie soils of Alabama and Texas. Johnson grass is somewhat tender and will not stand the cold winters of the North but can be grown successfully throughout the southern humid region, that is, the 
Cotton Belt. While best adapted to meadows, it can be used for pasture but does not well withstand the trampling of stock. Furthermore there has been some trouble from the poisoning of stock as the plants under certain conditions may produce hydrocyanic acid as do sorghum and its allies. Johnson grass is closely related to the sorghums, belonging to the same genus, hence might be expected to produce the same poison.

Notwithstanding the fact that Johnson grass gives excellent results as a meadow grass, it becomes under certain conditions an extremely pestiferous weed. This is due to its aggressiveness. After once occupying a field, it is eradicated with great difficulty. For this reason, many farmers hesitate to plant it or allow it to obtain a foothold upon their places. In another paragraph will be given directions for eradicating this grass when a meadow is needed for other purposes.

Eradication of Johnson Grass.-The eradication of Johnson grass depends upon suppressing the growth of the rootstocks.* Where cultural methods can be used it is recommended that the infested field be turned into a meadow or pasture and that the grass be kept closely cropped, either by grazing animals upon it or by mowing it for one or more seasons. If the plants are not allowed to blossom the rootstock development is reduced and what is produced remains near the surface. After the sod has remained undisturbed for a year the soil is plowed shallow, thus throwing up most of the rootstocks.

* A full account of the experiments with Johnson grass and the different methods tried in Texas for its eradication will be found in Farmers' Bulletin 279 (U. S. Dept. Agr.). 
The field is then planted in a cultivated crop. This crop should be given extra cultivation and stray plants of Johnson grass pulled up by hand when it heads out.

In regions where Johnson grass is common it may be rotated with grain. The sod is broken in the late summer and oats or other small grain sown in the early fall. After the grain is harvested in the spring the grass is allowed to grow and will produce two or sometimes three crops of hay. In the late summer the land is again broken for the small grain. In this way a fair crop of grain is secured in addition to a good hay crop.

Description.-Stems rather stout, erect, 3 to 5 feet tall, producing strong scaly rootstocks; sheaths smooth; blades flat, smooth, roughened on the edges, I to 3 feet long, $I / 4$ to $I / 2$ inch wide, tapering to a fine point, the white midrib conspicuous; panicle 6 inches to 2 feet long, large and open like oats or sorghum, usually purplish, the branches 2 to 4 together, naked below; spikelets somewhat crowded along the upper half or twothirds of the branches. The blades and sheaths are often splashed with purple as in sorghum, this being due to a bacterial disease.

Details of the Spikelet.-Spikelets in pairs or the terminal in 3's, one sessile and fertile, the other I or 2 pediceled and staminate. Fertile spikelet about $5 \mathrm{~mm}$. long, dorsally flattened, elliptic or ovate-lanceolate, indistinctly nerved, firm and coriaceous, often bearing a twisted and bent awn about as long as or a little longer than the spikelet, at first pubescent but later becoming smooth and shining on the exposed parts. Staminate spikelets more slender, slightly longer than the fertile, 


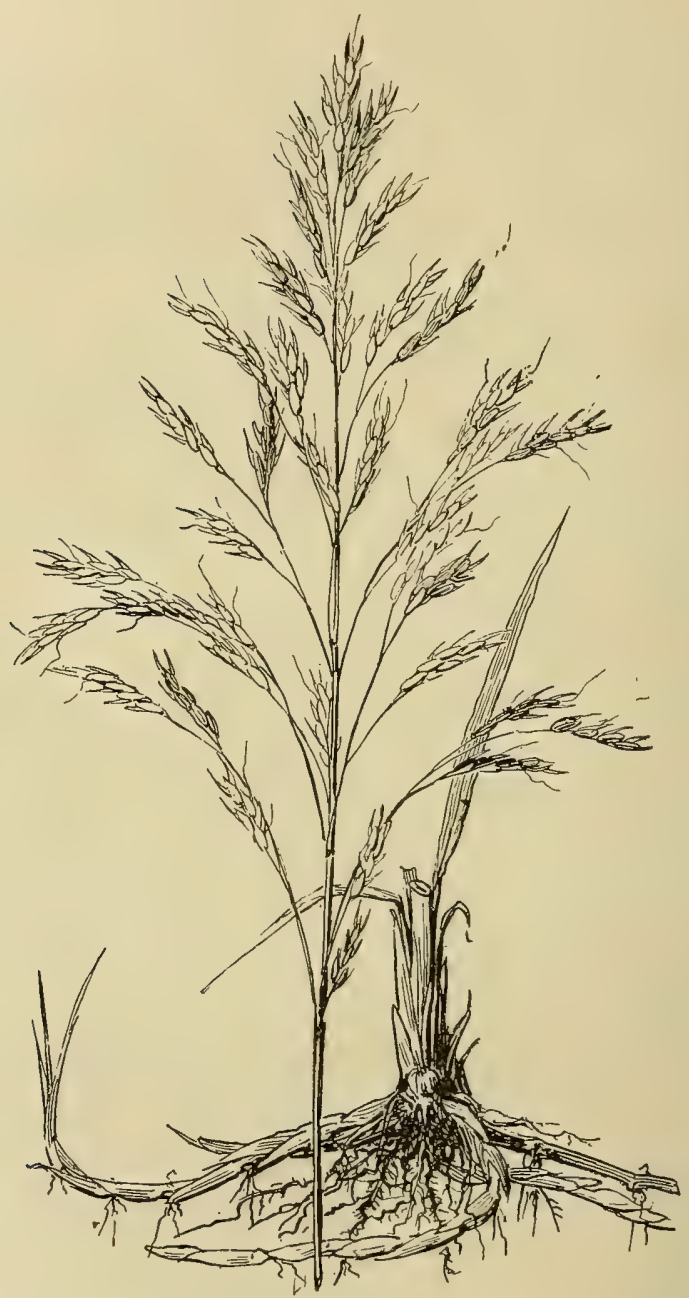

ı. Johnson Grass. A flower head or panicle, and a base showing the strong creeping rootstocks by which the grass spreads and which render it such an aggressive weed. 
distinctly nerved, membranaceous, the pedicel about half as long as the fertile spikelet, ciliate.

When threshed, the fertile spikelet or seed loses its awn and the staminate spikelets, and disarticulates from the pedicel but retains the I or 2 pedicels of the staminate spikelet which stand behind the seed.

Common Name.- Johnson grass is universally used in the United States for this species, being one of the few species to which but one common name has been applied. In Cuba it is called hierba de Don Carlos.

Botanical Name.-Holcus halepensis L. The name Holcus was originally applied to sorghum and its allies. Linnaeus used this name, but included in the genus several diverse species which have since been transferred to other genera. The specific name refers to the town of Aleppo in Syria. The species has been referred to Andropogon as $A$. halepensis Brot., and has also been called Sorghum halepense Pers.

\section{BROME GRASS}

This grass was introduced into the agriculture of the United States and grown on a commercial scale in the latter part of the last century, mostly since I 890 . The grass is a native of Europe and was introduced into cultivation there a few years before it came into notice here. Brome grass has proved of value in the region from northern Kansas to western Minnesota and westward to eastern Washington. It is more drouth resistant than the ordinary eastern meadow grasses and consequently fits into the agriculture of the region mentioned, where the conditions are too severe for 
timothy and clover. In many parts of the humid region

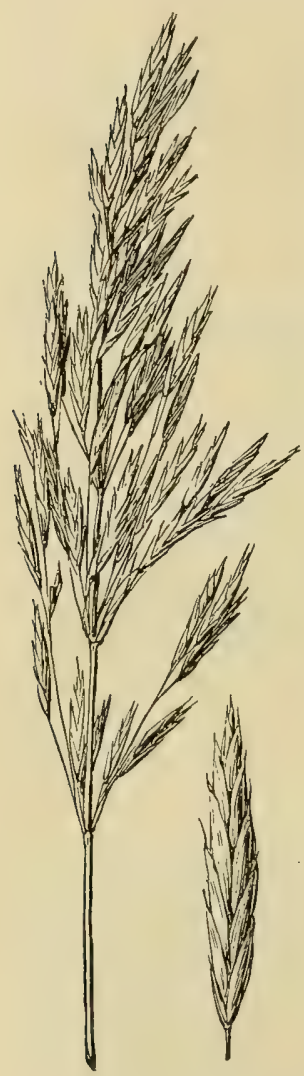
especially in Wisconsin and from Ohio to Virginia brome grass may be grown but there it must compete with timothy which with sufficient moisture gives a greater yield. In the more arid districts especially toward the south, brome grass does not do well except when irrigated. Under irrigation, however, other grasses are usually more satisfactory. It is, therefore, of chief importance in the triangular region embracing the northern portion of the Great Plains and extending further west along the northern border of the United States.

Brome grass can be used for meadow or for pasture. The seed may be sown in the spring or in the fall, or at any time between when the conditions are favorable. It is especially valuable for pasture, the vigorous rootstocks forming a firm sod. In a few years

Ir. Brome Grass. A these rootstocks occupy the soil head or panicle, and a single spikelet enlarged. to such an extent that it often becomes necessary to loosen up the ground by disking, or it may be advisable to plow up and reseed. 
The seed is light and chaffy, weighing I 4 pounds to the bushel. It is usually sown broadcast at the rate of 20 pounds per acre.

Description.-A hardy smooth erect perennial, usually 2 or 3 feet tall, producing strong creeping rootstocks. Blades flat, $\mathrm{I} / 5$ to $\mathrm{I} / 3$ inch wide, somewhat roughened, bearing at the base a pair of minute auricles. Panicles or flower heads 4 to 6 inches long, somewhat open and spreading, the branches naked below, the lower in clusters or fascicles.

Details of the Spikelet.- Spikelets about an inch long, brown or purplish, 8 to Io-flowered, slightly flattened; first glume narrow, acute, I-nerved, $5 \mathrm{~mm}$. long, the second broader and longer, obtuse, 3 -nerved; lemma 5 to 7 -nerved, the nerves scabrous, the apex awnless or with a very short awn.

Common Names.-The name brome is taken from Bromus, the botanical name of the genus. Other names applied occasionally to the species are: awnless brome grass, because the spikelets are nearly or quite awnless, while many species of the genus are awned; Hungarian brome grass, because it was grown in Hungary whence seed was obtained for trial in this country; smooth brome grass, because it is not hairy. Many farmers know it by its botanical name, Bromus inermis.

Botanical Name.-Bromus inermis Leyss. The generic name is from the Greek name for food, and was applied by the Greeks to oats.

Linnaeus gave the name to a group of grasses now known to include numerous species, both native and foreign. The specific name, meaning unarmed, refers to the absence of awns. 


\section{CHAPTER VIII}

\section{GRASSES OF MINOR IMPORTANCE}

THERE are several kinds of grasses that are mentioned in books on forage plants and in seed catalogues, which are of minor importance either because of the restricted area in which they may be grown or because of the limited use to which they are put. While these grasses are of little importance commercially, it is necessary that the farmer should be acquainted with them in order that he may not be misled by the too sanguine opinion of the writers in the farm journals, or by the flamboyant advertisements in seed catalogues.

\section{RHODE ISLAND BENT AND CARPET BENT}

These two grasses are closely related to redtop but are more delicate, the leaves being finer, the stems thinner and not so tall, and the panicle smaller and more open. Both grasses are suited to lawns and golf courses, as they produce a fine close turf. They do not produce rootstocks as does bluegrass but the stems are creeping at the base, especially those of carpet bent.

The bent grasses thrive on lime-poor soils in New England and many parts of the North and Middle Atlantic States, in fact, in about the same region that is favorable for redtop.

The method of preparation of a lawn with these grasses is similar to that given under bluegrass. Success de- 
pends much upon using seed of good quality. From 60 to Ioo pounds of seed should be used per acre. The seed should be examined and the proportion of seed and chaff noted. If the proportion of chaff is large, the amount of seed used should be increased. In the southern portion of the range, the seeding should be done in the early fall; in the north, it should be done in the spring.

Rhode Island bent is a common and well-established grass in New England and in many places along the coast to the south. The seed is now rarely to be found upon the market, but the U.S. Department of Agriculture is encouraging its production and use. The seed that is now sold by seedsmen under the name of Rhode Island bent is imported from South Germany and consists mostly of carpet bent mixed with varying quantities of another kind of bent grass called velvet bent. The presence of velvet bent in samples of Rhode Island bent shows that it comes from Germany. This South German mixed bent is a satisfactory grass for lawns. Not infrequently seedsmen have sold ordinary redtop under the name of Rhode Island bent. As redtop is not well suited to lawns the substitution is harmful.

Description.-Rhode Island bent is closely related to redtop from which it differs in being lower and more delicate, with a smaller open rather few-flowered panicle. The stems are usually only about a foot high and the blades are narrower than those of redtop. An important difference is in the shape of the ligule. In redtop, the ligule is acute, as much as $\mathrm{I} / 4$ inch long. In Rhode Island bent the ligule is blunt, often not more than $\mathrm{I} / \mathrm{I} 2$ 
inch long. The stems may be erect at base or they may produce short stolons. The spikelets are about the same as in redtop, but average smaller.

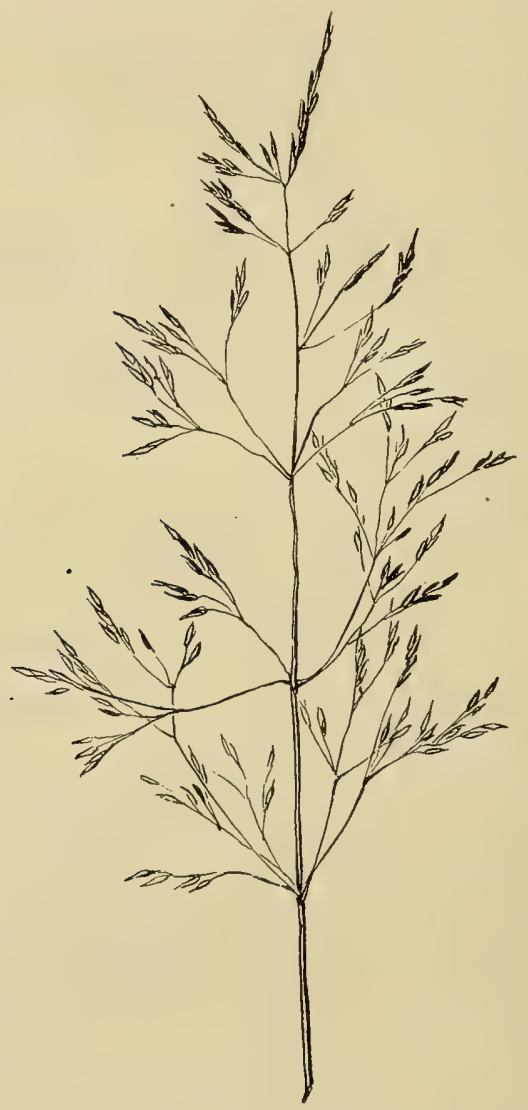

I2. Rhode Island Bent. A seed head or panicle.

Botanical and Common Names.-Agrostis capillaris L., Rhode Island bent, is a close alley of redtop. The 
specific name means hairlike. The grass was so named because of the delicate branches of the panicle. It has also been called Agrostis vulgaris With., Agrostis alba var. vulgaris (With.) Thurb. and Agrostis tenuis Sibth. Carpet bent, the chief ingredient of South German mixed bent, is Agrostis stolonifera L. Velvet bent is Agrostis canina $\mathrm{L}$. The seed of this is distinguished by the absence of a palea and the presence of an awn on the lemma. (See U. S. Dept. Agric. Bull. 692. The Agricultural species of Bent Grasses.)

\section{RYE GRASSES}

The two rye grasses may be considered together as they resemble each other closely, both botanically and agriculturally. English rye grass appears to be the first meadow or pasture grass brought into cultivation. Previous to this time, the latter part of the $\mathrm{i} 7$ th century, only wild meadows and pastures were known, these renewing and maintaining themselves spontaneously. Grasses were not sown, or if they sometimes were, it was a mixture gathered from the wild grasses. English rye grass is the first grass of which we have a record showing that it was cultivated as a distinct species, the seed being gathered and sown. The rye grasses, English and Italian, occupy a prominent place in European agriculture, having an importance far beyond that attained in this country. This difference is to be accounted for partly by the difference in climate and partly by the relatively higher cost and poorer quality of the seed in this country. Where timothy thrives, it cannot be displaced except by a grass distinctly better in some way. 
The rye grasses are more palatable than timothy or than almost any of our cultivated grasses, but the yield is not quite so good, and, at present, the seed is inferior in quality and higher in price. Our seed comes chiefly from Scotland and Ireland, and probably is not the best. The demand here has not been sufficient to induce the production of home grown seed.

The rye grasses are of considerable importance in the humid region of the Pacific Northwest where the climatic conditions are more nearly like those of Europe. They are used to a limited extent in the South for winter forage. Another use to which they are well adapted is that for lawns or public grounds and parks where a quick growth is required to cover the new soil. Rye grass is much used also as an ingredient in mixtures for lawns around residences. It gives a quick covering but is rather too coarse for use alone. As a lawn grass it is objectionable because it has no rootstocks nor stolons and hence does not form a compact sod; in a mixture, the bunches are large and the color different from other species, hence there is a lack of uniformity.

There are two kinds of rye grass in use, perennial and Italian, differing slightly botanically and agriculturally. Both kinds are short-lived perennials, Italian rye grass being practically an annual, and should be so treated agriculturally.

Over most of the region where the rye grasses are used, they are sown in the fall. In the South a good growth of winter pasture results. The seed weighs about 20 pounds to the bushel and should be sown at the rate of 2 to 3 bushels per acre, or at a proportional rate, if used in a mixture. 
Description.-English rye grass is a short-lived perennial tufted glossy dark-green grass, with flowering stems I or 2 feet tall, narrow flat blades usually less than $\mathrm{I} / 6$ inch wide, and a long flat narrow flower head, consisting of many flat several-flowered spikelets arranged in 2 rows along a main axis, the whole head as much as a foot long. The spikelets are $\mathrm{I} / 3$ to $\mathrm{I} / 2$ inch long and are placed edgewise on the axis, alternating on opposite sides. Only the outer glume is present on the lateral spikelets. On the terminal spikelet both glumes are present. The leaves of rye grass have one peculiarity which distinguishes it even when not in flower. At the base of the blade or the summit of the sheath are two little clawlike appendages, one on each side. These appendages or auricles are formed also on rye, wheat, and barley but on none of the cultivated meadow grasses except the rye grasses and meadow fescue.

Italian rye grass is distinguished from English rye grass chiefly by the presence of awns on the florets of the spikelets, these awns being as long as the florets or longer. In Eng-

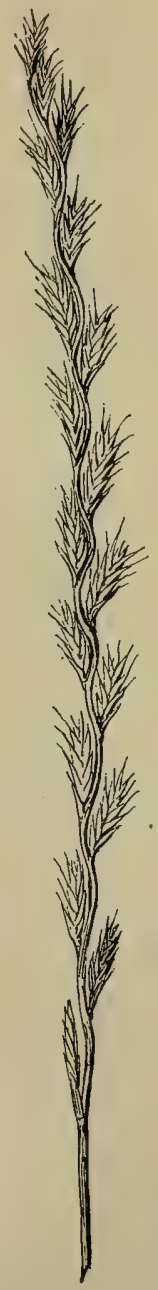

13. Italian Rye Grass. 
lish rye grass the florets are without awns or the awns are very short.

Common Names.-English rye grass is also known as perennial rye grass.

On the Pacific Coast, Italian rye grass is often known as Australian rye grass, as the seed was imported from Australia.

The rye grasses are sometimes known as ray grasses. The name rye grass is a misnomer as the species are not

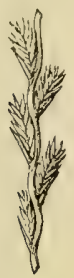

I4. Perennial Rye Grass. The spikelets without awns or bristles. closely related to rye botanically, nor do they resemble rye, except possibly in their early growth. In England the name darnel is used for English rye grass.

Botanical Names. - English rye grass is Lolium perenne L. Lolium is an old Latin name that was taken up by Linnaeus and applied to this grass. The specific name means perennial, a name used by Linnaeus to distinguish this grass from an annual species described at the same time.

Italian rye grass is Lolium multiflorum Lam. This species was distinguished by Lamarck nearly half a century after the preceding species was named. The specific name, many-flowered, refers to the number of florets in the spikelet. Italian rye grass has also been known as $L$. italicum A. Br. Some botanists consider the two forms to be but varieties of a single species. The name then would be $L$. perenne var. multiflorum Parn. or L. perenne var. italicum Parn. 


\section{TALL OAT GRASS}

Tall oat grass is used in Europe as a constituent of meadows and pastures but in this country it is used to a very limited extent. It is adapted to the timothy region and is used in mixtures for meadows. Its chief drawback is the high cost of the seed due chiefly to its poor seed habits. The seed does not all ripen at once and shatters readily so that only a small portion can be gathered at any one time. Furthermore, the forage from this grass is not very palatable to stock, at least not until they have become accustomed to it. Tall oat grass is not likely to compete with timothy in this country, but will be increasingly used in mixtures.

Tall oat grass is a native of Europe and is found in this country occasionally in waste places and along roadsides in the humid region.

Description.-A tall erect perennial, 3 to 4 feet high, with smooth sheaths, flat narrow blades not over $\mathrm{I} / 4$ inch wide, rough on both surfaces, and a long narrow rather loose, pale or purplish, shining panicle, 6 to Io inches long, the short branches in clusters. Spikelets 2 -flowered, about I/ 3 inch long, the first glume $I / 2$ as long, the second glume nearly as long as the spikelet, the first floret staminate, bearing a bent awn from the back twice as long as the lemma, the second floret fertile, awnless.

A variety of this, called bulbous oat grass is found occasionally as a weed in Virginia and North Carolina where it has recently been introduced from Europe. This has a series of beadlike joints at the base of the stems.

Common and Botanical Names.-Tall oat is so named because of a fancied resemblance to oats. It is also 


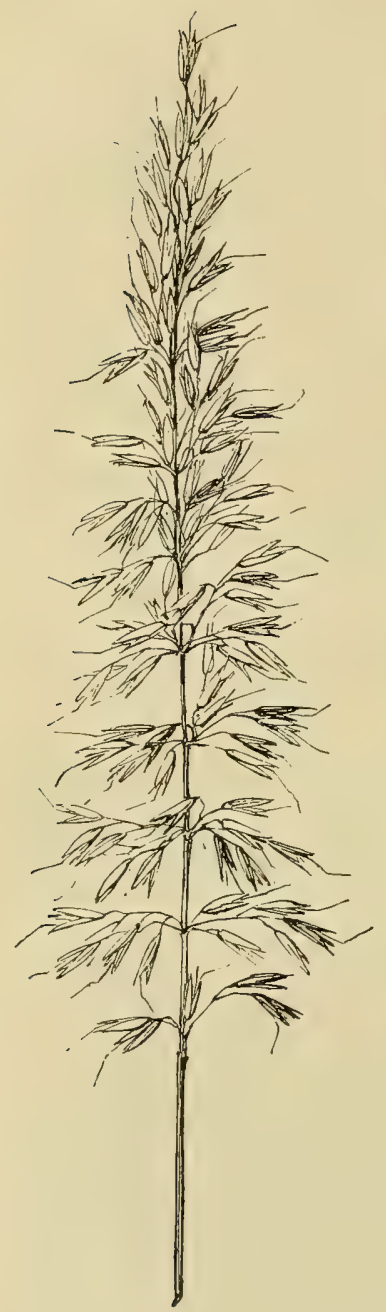

15. Tall Oat Grass. A head or panicle in flower. At maturity the panicle contracts. called tall meadow oats, or tall meadow oat grass. Another name occasionally used is Randall grass:

The botanical name is $A r$ rhenatherum elatius(L.) Beauv. The generic name is derived from two Greek words which mean masculine and awn, referring to the awned staminate floret. The specific name means taller. Other names occasionally seen in seed catalogues are Arrhenatherum avenaceum and Avena elatior. The variety with bulbs is $A r$ rhenatherum elatius var, bulbosum (Presl) Koch.

\section{CANADA BLUEGRASS}

Canada bluegrass is used for pasture on sandy or sterile soil in the timothy area. On good limestone soil suited to the growth of Kentucky bluegrass, Canada bluegrass cannot compete with the former. Canada bluegrass is sometimes used for lawns as it forms a firm sod, but, except on sandy soil, is not so satisfactory as Ken- 
tucky bluegrass. It may be used for hay, producing a good quality but a small yield. On the whole, Canada bluegrass is of no importance except under conditions not suited to Kentucky bluegrass. The seed is nearly all produced in the southeastern part of the province of Ontario west of Niagara Falls.

Description.-The plants produce numerous tough creeping rootstocks which form a firm sod. The stems are not tufted but arise from ther ootstocks singly. Stems usually about a foot high, distinctly flattened, the blades rather short and upright. Panicle smaller and narrower than that of Kentucky bluegrass. The florets (the seed of commerce) resemble those of that species and are used to adulterate its seed. The color of the plants of Canada bluegrass is distinctly bluish green as distinguished from the dark green of Kentucky

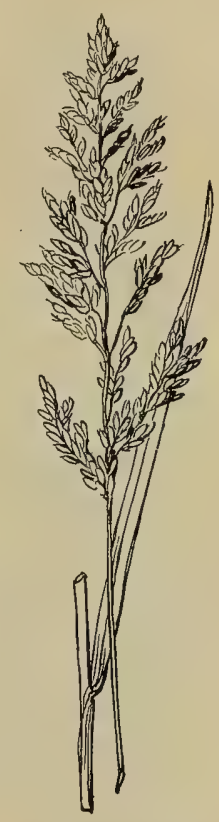

I6. Canada Bluegrass. A flower head or panicle and a single leaf. bluegrass.

Botanical and Common Names.-The botanical name is Poa compressa L. It belongs to the bluegrass genus as is indicated by the first part of the name. The specific name compressa (compressed) refers to the flat stem.

The recognized common name is Canada bluegrass or the variant Canadian bluegrass. Other names are Eng- 
lish bluegrass, wire-grass and flat-stem. The last name is much used in the mountains of West Virginia. The

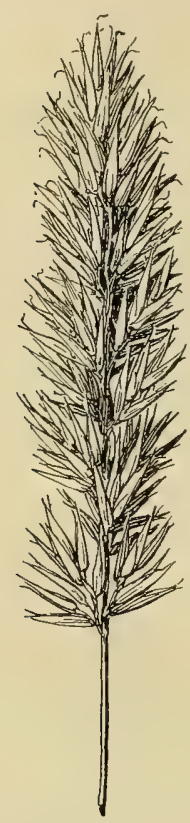

I7. Sweet Vernal Grass. A single head or spike in flower. After flowering, the head closes up and becomes more dense. term wire-grass is not distinctive as it is used for several other species.

Canada bluegrass is probably not a native of North America though it is now common in grassland, along roadsides, and in waste places throughout the Northern States and southern Canada. It is common in the cooler parts of Europe.

\section{SWEET VERNAL GRASS}

Sweet vernal grass is useless as a forage grass but is sometimes included in meadow mixtures to give a pleasant odor to the hay. It contains cumarin, a constituent found also in vanilla grass, which is also fragrant, especially when the grass is dried. Sweet vernal is an erect perennial, I or 2 feet high, with thin flat blades I to 3 inches long, and a dense spikelike bronze-green panicle I to 3 inches long, narrowed above and below, the short branches spreading in flower.

The spikelets are 8 to Io $\mathrm{mm}$. long, lanceolate, acuminate; glumes sparsely pilose, the first about half as long as the second; fertile lemma smooth and shining, much shorter than the glumes; standing on either side of the 
fertile lemma are two sterile lemmas about twice as long, one being short-awned, the other bearing a long twisted and bent awn from near its base.

The botanical name is Anthoxanthum odoratum L. Sweet vernal is a native of Europe and is found growing as an escape from cultivation in the Eastern States. The generic name means yellow flower; the specific name refers to the odor.

\section{VELVET GRASS}

Velvet grass is occasionally used for meadows in the humid region but has little value except on sterile or sandy soil. The hay is not relished by stock until they acquire a taste for it. On fertile soil it cannot compete with more valuable grasses, but on sandy soil it gives better returns than most other meadow grasses. The only part of the country where it becomes of importance is on the sandy land along the Columbia River in Oregon and Washington, and a few other places from Northern Cali-

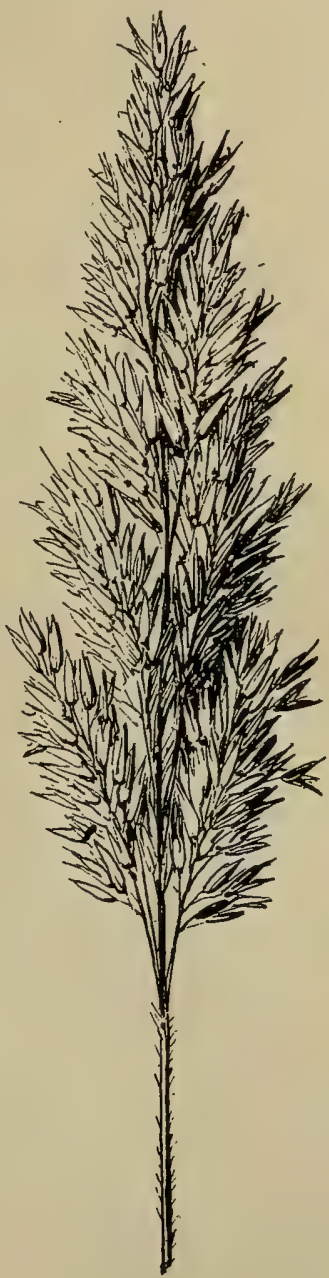

I8. Velvet Grass. A head or dense panicle. After flowering, head closes up. 
fornia to British Columbia. In this region it is a weed and at times becomes a pest. Velvet grass has been long known in Europe where it is used in mixtures.

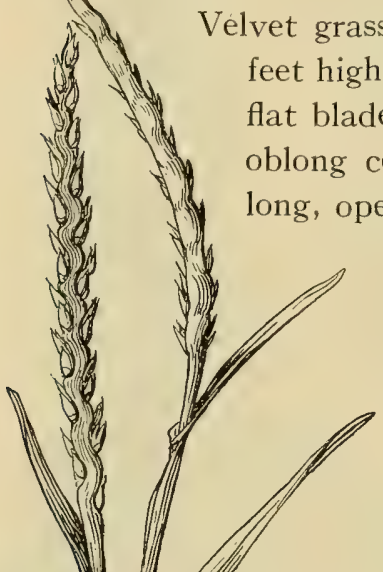
and almost spike-like at other times. The panicle is soft and pale or purplish in color.

The spikelets are about $\mathrm{I} / 5$ inch long, with pubescent glumes longer than the 2 florets, the upper of which bears on the back a hooked awn.

Velvet grass is sometimes incorrectly called mesquite. In England it has other names, such as meadow soft grass and Yorkshire fog, little used in this country. The botanical name is Notholcus lanatus (L.) Nash. It has also been called Holcus lanatus L.

\section{ST. AUGUSTINE GRASS}

St. Augustine grass is much used as a

I9. St. Augustine Grass. Thê upper part of a plant showing two seed heads or spikes. lawn grass in alluvial or mucky soil near the coast from North Carolina to Florida and Louisiana. It is a creeping perennial with flat stems, rather short, 
abruptly pointed leaves and a flat spike in which the spikelets are imbedded. The flower stalks are usually only a few inches to a foot high. The foliage somewhat resembles that of carpet grass. To establish a lawn, the cuttings of the runners are set out. St. Augustine grass is a native of the Coast region of the warmer parts of America. The botanical name is Stenotaphrum secundatum (Walt.) Kuntze.

\section{CARPET GRASS}

Carpet grass is used for pasture in the alluvial bottomlands of the Southern States especially near the coast from Georgia and Florida to Louisiana. On dry sandy land or on the drier uplands it does not compete with Bermuda grass but attains its maximum growth on moist mucky or sandy soil along the Gulf Coast.

Carpet grass is a creeping perennial forming long runners which throw up flowering stems 6 to 20 inches high. The blades are comparatively short, the margins parallel, the apex abruptly pointed. The stems and sheaths are flattened. The inflorescence consists of 3 or 4 slender spikes clustered at the summit of the stems.

The species is a native of tropical America and is abundant from Brazil, through the West Indies to the Southern United States. It withstands grazing and trampling and tends to occupy open moist alluvial soil. These qualities eminently fit it for a pasture grass. It can be started by planting cuttings. These grow rapidly and soon occupy the land.

Carpet grass is much used near the coast as a lawn grass, for which purpose it is well suited. 
IO

A MANUAL OF FARM GRASSES

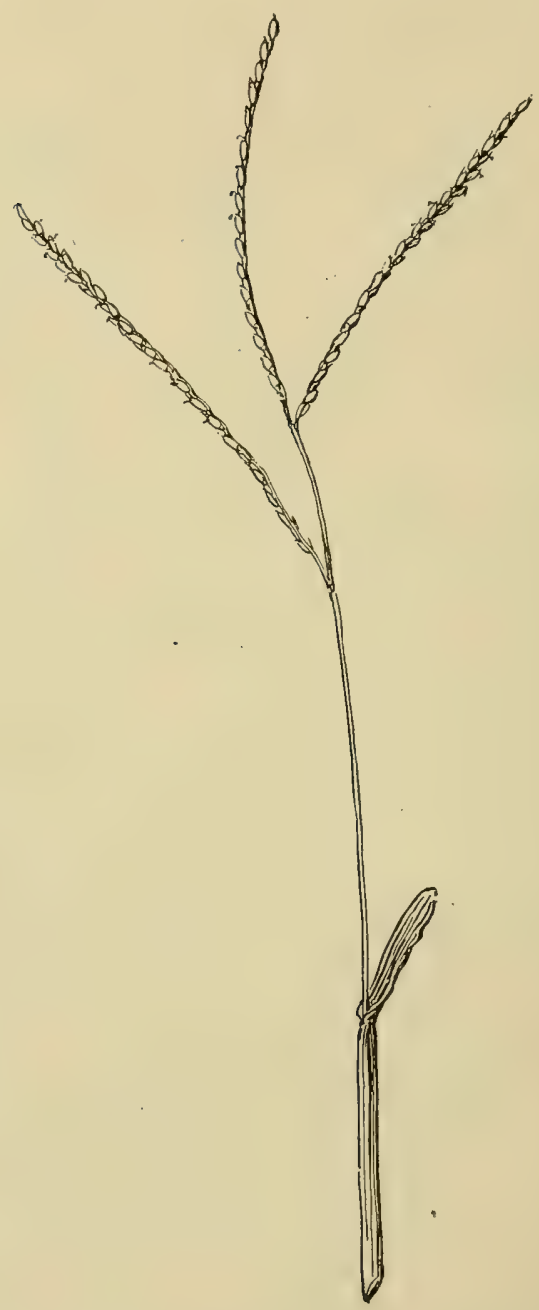

20. Carpet Grass. The upper part of a flower stem, showing three spikes. 
The botanical name is Axonopus compressus (Swartz) Beauv. It has been called Paspalum compressum Rasp. and Anastrophus compressus Schlecht.

\section{RESCUE GRASS}

Rescue grass is occasionally grown in the Southern States for winter forage. It is an erect annual grass I to 3 feet high, the panicle bearing a few spreading branches and rather few large flat spikelets $\mathrm{I} / 2$ to $2 / 3$ inch long. The spikelets are several-flowered, the lemmas sharp-pointed and sometimes slightly bristle-pointed but not awried. Rescue grass is a native of South America. It is also known as Schrader's brome grass and Australian brome grass. The botanical name is Bromus unioloides H. B. K.

\section{GUINEA GRASS}

Guinea grass is the most important cultivated forage grass of tropical America. Like most tropical forage plants it is cut and fed green. In the United States it can be grown only in southern Florida and southern Texas. It is an erect perennial, growing in large dense bunches, the stems 4 to 8 feet high, with flat blades and a large open spreading panicle $\mathrm{I}$ to 2 feet long with numerous small green elliptic spikelets about I/8 inch long. Guinea grass is a native of Africa. Its botanical name is Panicum maximum Jacq.

\section{PARA GRASS}

Para grass is another important tropical forage grass which can be grown in the United States only in southern Florida and southern Texas. Para grass is a perennial 


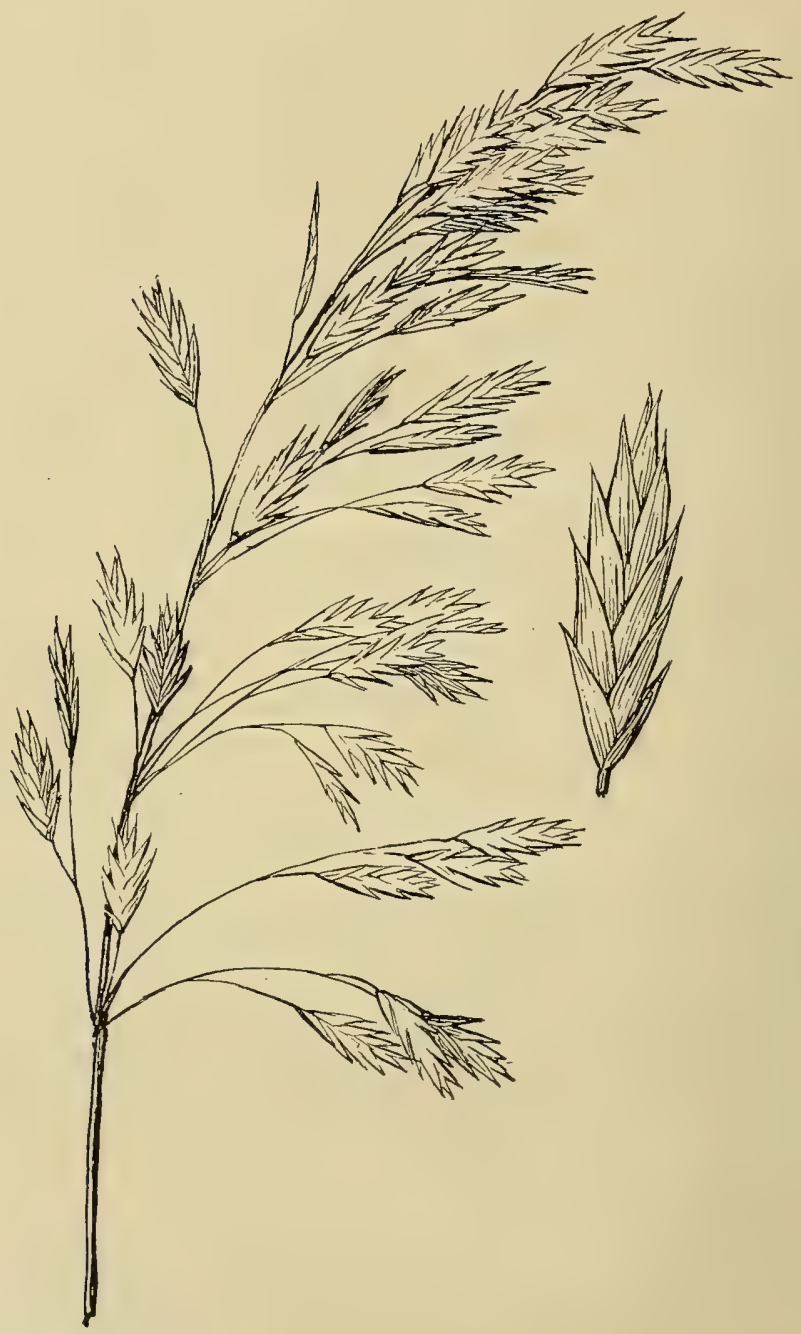

21. Fescue Grass. A head or panicle and a single spikelet. 
with stout stems that rise above the creeping base to a height of 4 to 8 feet, bearing flat smooth blades and a terminal panicle 4 to 8 inches long, consisting of several short branches scattered along the main axis. The spikelets are elliptic, about I/8 inch long, crowded on the branches of the panicle. The creeping bases of the stems soon form a tangled mass which completely occupies the soil. The nodes or joints of the stem are densely velvety.

Para grass is readily grown from cuttings. The pasture must be renewed occasionally as the soil becomes so filled with the roots and tangled stems that the forage is greatly reduced. Para grass does not withstand trampling and is not well suited to pasture. In tropical countries it is used chiefly for soiling. Para grass is probably a native of Africa but is now cultivated throughout tropical America at low altitudes. The botanical name is Panicum barbinode Trin. It has been erroneously called Panicum molle Swartz, a name which belongs to a different species. In the Hawaiian Islands, Para grass is usually known as panicum.

\section{THE FESCUE GRASSES}

There are several European species of fescue grasses that are used to a limited extent in this country in lawn and pasture mixtures. They are low grasses with fine leaves, the flower stalk being 6 to 12 inches high. Some of the species are much used in Europe, especially on rocky or sterile soil. In this country they are of some use on the same kind of soil in New England and in other parts of the Northeast, giving some pasture where other species could not obtain a foothold. The fescue grasses 
are more widely used in lawn mixtures but in general they have no especial advantage over Rhode Island bent,

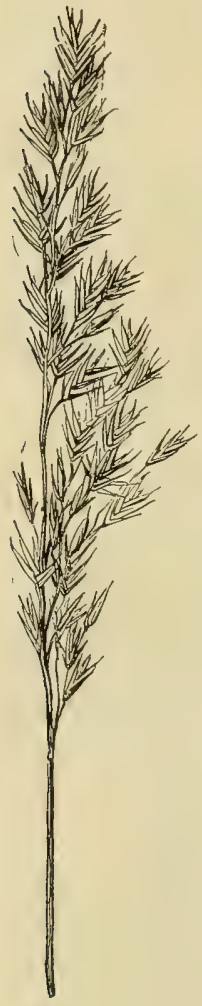

22. S h e e p's Fescue. A flower head or panicle. except that certain species give somewhat better results in partly shaded areas. Various-leaved fescue and fine-leaved fescue are often sown in those parts of a lawn that are less exposed to the sun, as under the larger trees.

The kinds of fescue grasses commonly sold by seedsmen are as follows:

Sheep's Fescue.-Growing in erect bunches, with - a tuft of firm, slender, rounded or needle-like leaves at base, the flower-stems 6 to 12 inches high. Panicle narrow, 2 to 4 inches long, spreading in flower but contracted afterward, the spikelets somewhat one-sided. Spikelets about $1 / 4$ inch long, 3 to 6 -flowered, the florets narrowed into a short bristle. The botanical name is Festuca ovina L.

Slender Fescue.-Differs from sheep's fescue in having longer and more slender threadlike, rather soft blades. Botanically this and the next are usually considered as varieties of sheep's fescue, but by some are considered to be distinct species. Festuva ovina capillata (Lam.) Hack.; Festuca capillata Làm.

Hard Fescue.-Differs from sheep's fescue in having harsher, firmer and thicker blades. Those of sheep's fescue are about I/24 
inch thick, while those of hard fescue are about twice as thick, I/I2 inch. Festuca ovina duriuscula (L.) Koch. Festuca duriuscula L.

Red Fescue.-This is a distinct species with a somewhat creeping base. The leaves are less densely tufted at the base than in sheep's fescue, and are smooth to the touch. The stems may grow to be 2 or 3 feet high. The spikelets are similar to those of sheep's fescue, but the bristle on the florets is longer, about half as long as the floret. Festuca rubra L.

Various-leaved Fescue.-A variety of red fescue with more slender softer leaves. The plants are more densely tufted. Often used in shaded places on lawns. Festuca rubra heterophylla (Lam.) Mut.; Festuca heterophylla Lam.

\section{RHODES GRASS}

- Rhodes grass is a native of South Africa that has recently been introduced into this country where it has been tested as a forage grass. It promises to be of some value in the warmer parts of the country from Florida along the Gulf coast to Texas and in the irrigated regions of the Southwest and also in the drier parts of the Hawaiian Islands. Rhodes grass is a perennial which forms creeping stems that throw up at intervals erect flowering stems 2 or 3 feet high. The inflorescence is made up of several slender one-sided spikes aggregated at the summit of the stem forming an open tassel. The botanical name is Chloris Gayana Kunth. (See U. S. Dept. Agr. Farmers' Bulletin I048.) 


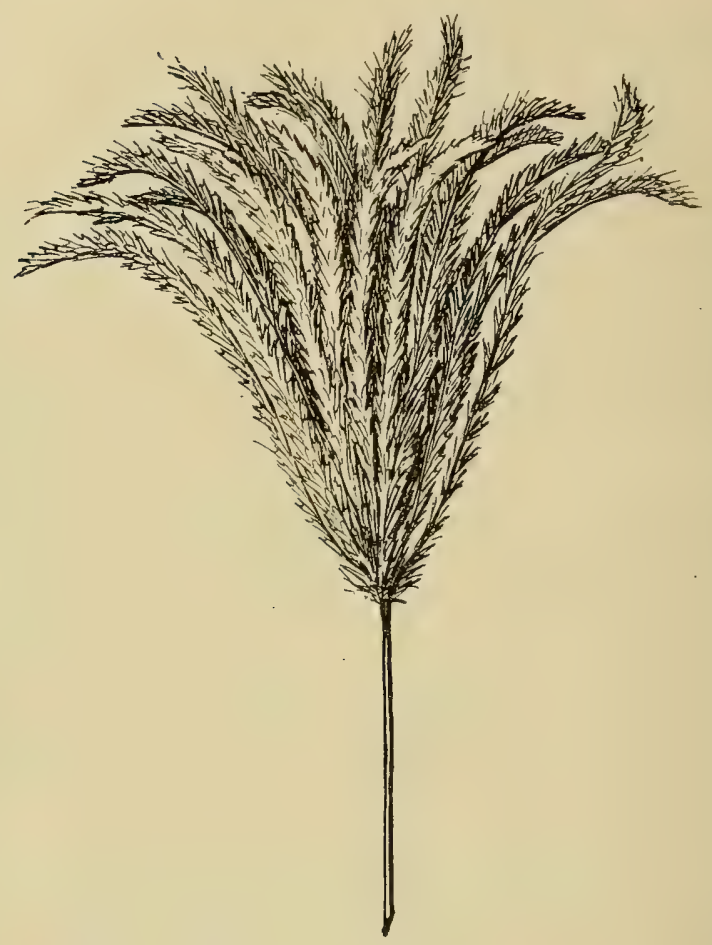

23. Rhodes Grass. A flower head, consisting of numerous spikes.

\section{NATAL GRASS}

Natal grass has been recently introduced as a meadow grass in the sandy lands of Florida where it has proved very successful. It is the only grass that has given satisfaction in the pine barrens of central Florida, usually known as high pine land, and in the drier parts. of the Hawaiian Islands. Another name for this grass is Natal redtop. 
Natal grass is an erect perennial, 2 or 3 feet high or sometimes taller. The inflorescence is a silky, pale or dark pink, rather congested panicle 4 to 8 inches long. It is a native of South Africa. The botanical name is Tricholaena rosea Nees.

Several cuttings of nu- tritious hay can be procured each year. It can be grown from the seed or by setting out divisions of the crown or root. Natal grass is tender and cannot be grown north of Florida or the vicinity of the Gulf Coast. It cannot compete with other grasses on rich alluvial soil but is well adapted to rather dry sandy soil.

\section{SLENDER WHEAT GRASS}

This is a native species found growing in the western part of the United States from Colorado to California and northward. It is a bunch grass with erect stems 2 to 4 feet tall. The structure of the seed head is the same as that of wheat, but the spikelets are smaller and more slender, the glumes

24. Natal Grass. 
rounded rather than keeled, the florets beardless or with short bristles. This species has been introduced into cultivation in the northern part of the Great Plains and the seed is offered for sale by seedsmen of that region. It is somewhat drouth resistant and produces a nutritious and palatable forage. The botanical name is Agropyron tenerum Vasey.

\section{A FEW OTHER GRASSES}

Paspalum dilatatum.-This grass has been recom- . mended as a forage plant in the Southern States but the trials have not shown that it has any special value. It is a moderately coarse perennial, growing to the height of 2 or 3 feet. The inflorescence consists of 2 to 5 spikelike racemes, sometimes more; growing along the upper part of the stem. These racemes are 2 to 4 inches long, onesided, the spikelets being crowded on one side of a flat rachis or axis. The spikelets are flat on one side and convex on the other, ovate, somewhat silky along the edges.

The name given above (Paspalum dilatatum Poir.) is the botanical name, by which the grass is generally known. It is sometimes known as water grass or water paspalum. It can be used for hay or pasture in the Southern States. On the basis of experiments with this grass it cannot now be recommended.

Paspalum dilatatum is finding much favor in the Hawaiian Islands as a pasture grass in the upland pastures where there is a fair amount of moisture. It is there call paspalum.

Texas Bluegrass.-Texas bluegrass is of little importance but has much to recommend it and may come 
GRASSES OF MINOR IMPORTANCE

I I 5

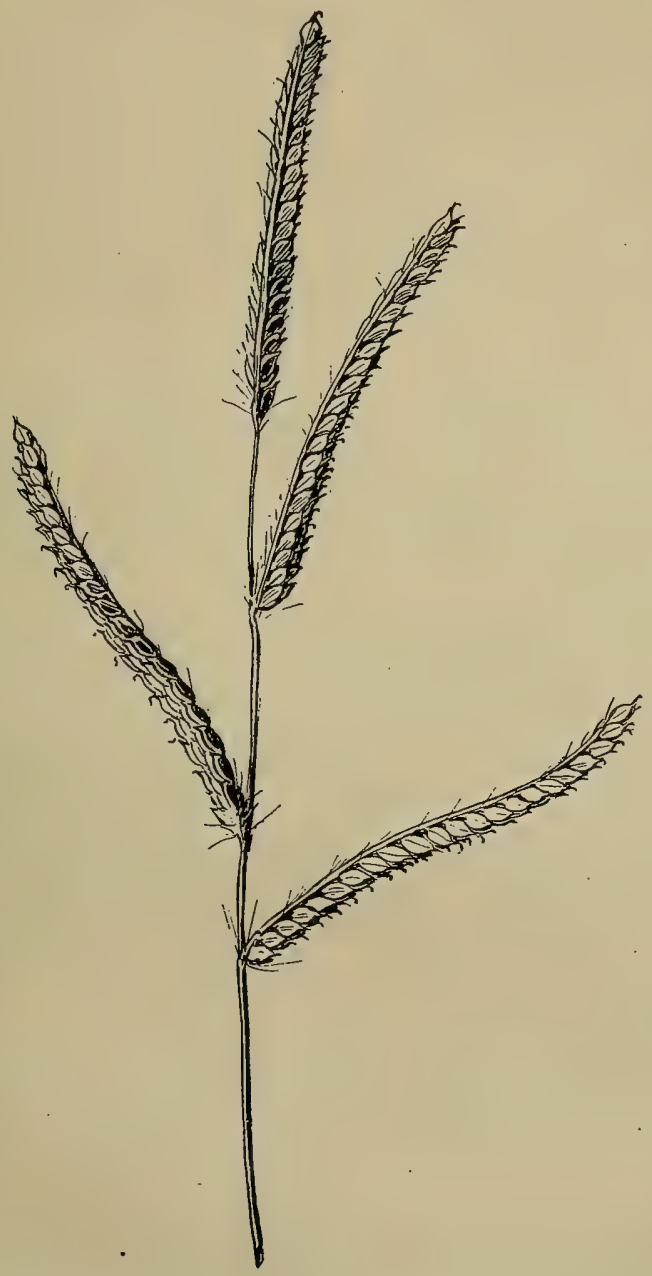

25. Paspalum dilatatum. An inflorescence or flower head of four spikes.

9 
into more common use in the future. It is a native of Texas and has been tried in many places in the south for winter pasture and for lawns. It remains green during the winter in the south, which is a strong point in its favor. The seed cannot be obtained upon the market and the plants must be started by planting pieces of the rootstocks. The plants spread by these and soon occupy the ground.

The stems are erect, I or 2 feet high, bearing contracted panicles 2 to 4 inches long. The plants are dioecious, that is the male and female flowers are borne on different plants. The seeds are very woolly. The botanical name is Poa arachnifera Torr.

Rough-stalked Meadow Grass.-Rough-stalked meadow grass resembles Kentucky bluegrass in appearance but does not produce creeping rootstocks. It is usually larger and more lax and can be easily distinguished by the rough sheaths. This species is occasionally cultivated in meadow or pasture mixtures upon wet soil.

The botanical name is Poa trivialis L. It belongs to the bluegrass genus. The specific name means common or ordinary.

Rough-stalked meadow grass is a native of Europe but is not infrequent as an introduced plant from New England to Louisiana and in the Pacific Northwest.

Fowl Meadow Grass.-This is a smooth, tufted grass without rootstocks, the stems I to 4 feet tall. The panicles resemble those of Kentucky bluegrass but are larger and more open, being from 4 to 12 inches long. 
It is a member of the bluegrass group. The spikelets are about I/6 inch long, with 2 to 4 florets. Like Kentucky bluegrass, the 3 prominent nerves of the lemma are silky-pubescent and there is a tuft of cobwebby hairs at the base. This grass is sometimes recommended for meadow mixtures, especially for moist soil. It grows commonly as an introduced species along the northern border of the United States.

The botanical name of fowl meadow grass is Poa palustris L. meaning marshy poa or poa growing in marshes. Other Latin names that have been applied to this are Poa triflora Gilib. and Poa serotina Ehrh.

Crested Dog's-tail Grass.-This species is used in Europe in mixtures for meadows and pastures but cannot be recommended for use in this country. It is a slender perennial I to 2 feet high with dense terminal spikelike panicles, the spikelets in clusters, the upper ones of each cluster being fertile, the lower ones larger and sterile, with narrow lemmas. The botanical name is Cynosurus cristatus L.

Meadow Foxtail.-Meadow foxtail is a European grass that in this country is occasionally sown in mixtures for meadows in the northern humid region. Although a frequent ingredient of meadows and pastures in Europe it is of no value in this country. Meadow foxtail somewhat resembles timothy in general appearance. The spike or head is dense and cylindric but is more flexible and softer to the touch. The spikelets differ in that the glumes are unawned but the lemma bears a 
slender awn or bristle from the back below the middle. The awns protrude beyond the spikelets giving the head a silky-bristly appearance. The botanical name is Alopecurus pratensis $\mathrm{L}$. The generic name is from two Greek words meaning fox and tail.

Napier Grass.-This is a native of tropical Africa recently introduced in this country for trial. It gives promise as a forage grass in Florida and west along the Gulf Coast to Texas and also in southwestern Arizona and southern California. Napier grass is a robust perennial growing to the height of 6 to I2 feet, with narrow spikes or heads 4 to Io inches long. It may be propagated from the seed, or from cuttings of the canes, or from divisions of the crown or root-clump. The botanical name is Pennisetum purpureum Schum. In Africa it is called elephant grass.

Carib Grass.-Carib grass is a native of the West Indies that resembles Para grass in general appearance but is more erect in its growth and hence more favorable for a hay crop. It can be used only in the extreme south in the region suited to Para grass. The botanical name is Eriochloa subglabra (Nash) Hitchc. 


\section{CHAPTER IX}

\section{ANNUAL FORAGE GRASSES}

ON account of their short life, the annual grasses are not, of course, suited to permanent meadow or pasture. Some of the annuals are sometimes used for temporary pasture, as in the case of rye, but their chief use is for hay. The hay of the coarse grasses, such as corn and sorghum, is called fodder. Another important use for many of the annuals is in soiling, or cutting and feeding green.

\section{COMMON MILLET.}

The term millet is used for several different kinds of grasses, but in the United States, when used without a qualifying word, refers to common or foxtail millet. Other kinds of millet are proso or broom-corn millet, pearl millet, Chinese millet, and Japanese barnyard millet, each of which is discussed under its appropriate heading. Among some primitive peoples, millet is grown for the grain which is used for food, but in this country it is used for forage only. Being an annual, it furnishes temporary meadow only. Millet is grown in the eastern half of the United States, but chiefly in the region from Oklahoma to Iowa. It is especially useful as a summer crop following grain, thus fully utilizing the land-a so-called catch crop. As the young plants are tender, the seed cannot be sown early. The hay is palatable and nutritious and is valuable for all kinds of 
stock, but must be fed to horses with caution as it may injure them if they are fed too exclusively on it. It should not be cut too late as the bristles on the heads become troublesome. Hungarian grass is a variety of millet.

Varieties of Millet.-There are several varieties of millet cultivated in this country and many more used in the old World.

Common millet, or what is generally known merely as millet, has rather small heads, 2 to 3 inches long, I/ 4 to $\mathrm{I} / 2$ inch thick, the bristles noticeably longer than the spikelets or seeds, the seeds pale (straw color to lightbrown), the bristles greenish or purple.

Hungarian grass has small dense heads, I to 3 inches long, with black or dark-colored seeds and purple bristles.

German millet has large lobed heads, 4 to I2 inches long, and as much as 2 inches thick, the bristles noticeably longer than the spikelets, the seeds pale, the bristles greenish or purple.

Golden Wonder millet differs from German millet in having bristles shorter than the spikelets or scarcely exceeding them.

A few other varieties have been recently introduced into this country and are sparingly cultivated.

Turkish millet has red seed, large lobed heads, and purple bristles.

Kursk or Siberian millet differs from the preceding in having a small dense head.

Aino millet has large lobed heads, brown bristles, and pale seed. 
Description.-An erect annual with flat blades, erect or often nodding spikelike panicles or "heads." The spikelets are in close clusters on the short branches of the panicle, interspersed with rough green, yellow, brown or purple bristles which usually exceed them in length. The spikelet itself consists of three bracts (2 glumes and a sterile lemma) inside of which is the fertile floret consisting of a hardened lemma and palea. At maturity, the ripened floret or fruit shells out of the spikelet and forms what is commonly called the seed. This varies in color in the different varieties from pale yellow to red brown or nearly. black.

Botanical Names.-Chaetochloa italica. (L.) Scribn. Millet was first described by Linnaeus under the genus Panicum as $P$. italicum $\mathrm{L}$. Later this and allied species were separated as a distinct genus under the name Setaria, this species becoming $S$. italica Beauv. As the name Setaria had been previously applied to a genus of lichens, the name of the millet genus was changed by Scribner to Chattochloa. Many botanists still use the name Setaria. Both names refer to the bris-

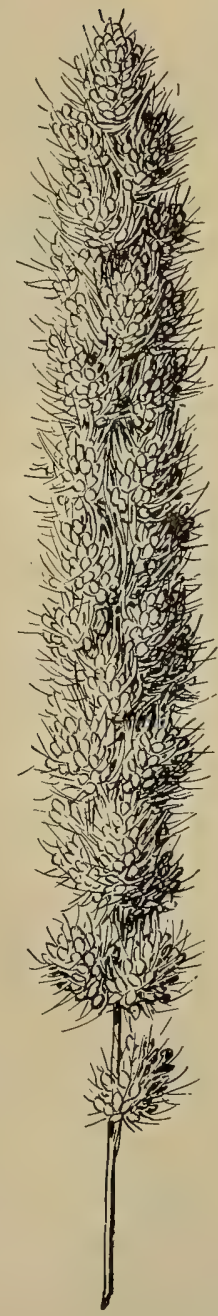

26. German Millet. A single seed head. 
tles around the spikelets, Setaria, from the Latin seta, a bristle, and Chaetochloa, from the Greek chaeta, a bristle, and chloa, grass. The specific name

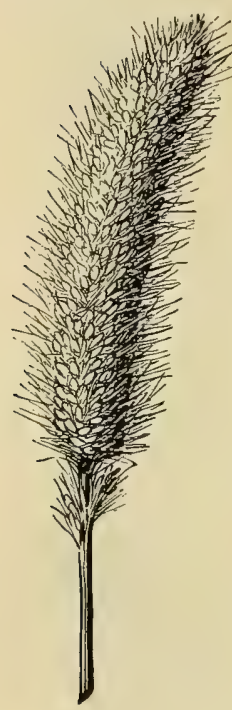

27. Hungarian Grass. A single seed head. is a geographical adjective referring to Italy, a country where millet was much grown.

Foxtail Grass. - Allied to the cultivated millet are two wild species that have been introduced into this country and are now common weeds in the Eastern States. One, with a cylindrical yellow head, is yellow foxtail; the other, with a slightly tapering head, is green foxtail. Both are called, in some localities, pigeon grass. It is sometimes difficult to distinguish green foxtail from depauperate specimens of millet. If the ripe head of green foxtail is rubbed between the fingers to shatter the seed, the spikelets fall off with the glumes surrounding the seed. If ripe millet is treated in the same manner the seed falls out free from the glumes.

\section{PROSO MILLET}

Proso or proso millet is commonly grown in Europe and western Asia, the seeds being used for food. In this country it is grown to a limited extent for forage and sometimes for the seed which is used for hogs. Although proso can be grown successfully in many parts of the United States, it has not been received with much favor 


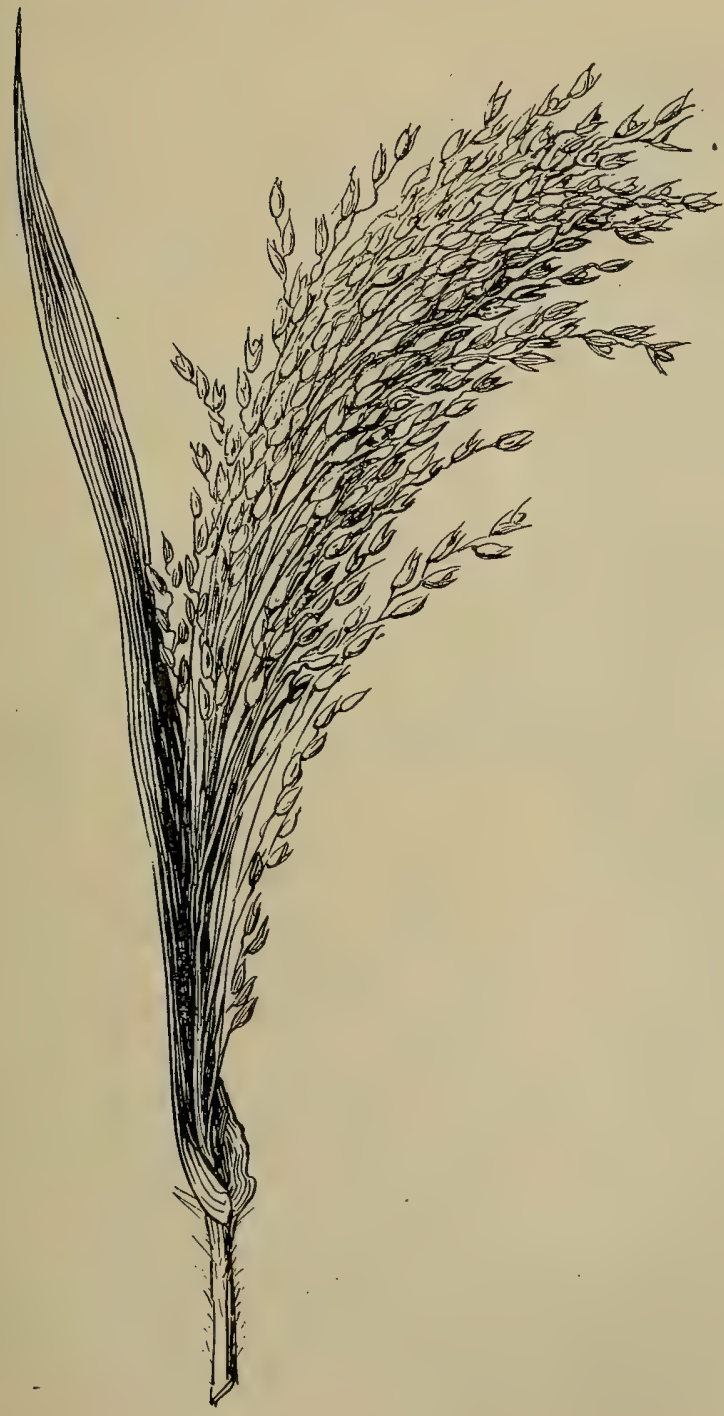

28. Proso or Broom-corn Millet. 
as it cannot compete with forage crops already grown in the same regions.

Description.-Proso is an annual 2 or 3 feet tall, with bristly sheaths and an open finally heavy and drooping panicle. The spikelets are elliptical, smooth, pointed, the first glume about half as long as the spikelet, 3nerved, the second glume and sterile lemma equal, several-nerved. The fertile lemma or fruit (commonly called the seed) is smooth and shining, oval, somewhat flattened on one side, yellowish or brownish, about $3 \mathrm{~mm}$. long ( $1 / 8$ inch).

Botanical and Common Names.-The botanical name is Panicum miliaceum L. Besides the name proso it is known in Europe as common millet. In this country it is sometimes called hog millet because the grain is used for hog feed, and sometimes broom-corn millet because the fruiting panicle looks something like a head or panicle of broom-corn.

\section{JAPANESE BARNYARD MILLET}

Japanese barnyard millet is sometimes advertised by seedsmen but it has not shown that it has advantages over the forage plants now in use. It is grown in some parts of tropical Asia and Africa for the grain which is used for human food. In this country it has been recommended for hay. The species can be grown at low altitudes throughout the United States except in the extreme North, but requires plenty of moisture. Under favorable conditions the yield is fairly heavy. However, the grass is succulent and when cut dries slowly so that the curing of the hay is a rather slow process. Altogether it is a 
grass that has little to recommend it for cultivation in this country. It is entirely unsuited for growing in regions deficient in moisture. Under irrigation, there are other forage plants that are more satisfactory.

Description.-An erect smooth succulent annual, 2 to 4 feet tall, with flat blades, and a narrow rather compact panicle or head made up of numerous short spikes about an inch long, these ascending or appressed. Spikelets crowded, ovate, flattish on one side, somewhat pointed but not awned, about $3 \mathrm{~mm}$. (I/8 inch) long, covered with short, stiff hairs. First glume $\mathrm{I} / 3$ the length of the spikelet. The spikes are somewhat incurved. The whole inflorescence usually 3 or 4 inches long.

Botanical and Common Names. Echinochloa crusgalli edulis Hitchc. It is also known as Panicum frumentaceum Roxb. It is a variety of Echinochloa crusgalli, the common barnyard grass, a weed of moist places and cultivated soil, which differs in having awned spikelets, the awn often several times as long as the spikelet. Japanese barnyard millet has been advertised by seedsmen as billion dollar grass:

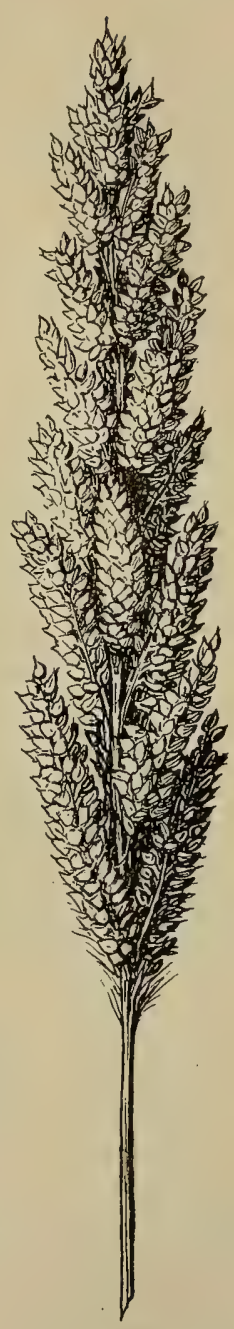

29. Japanese Barnyard Millet. A seed head. 


\section{PEARL MILLET}

Pearl millet is a tall coarse annual grass, with broad leaves and a cylindric spike or seed head as thick as one's thumb and about a foot long. The growth resembles that of sorghum, the stems being 6 to ro feet tall, but the cylindric seed head is different from that of any other grass in cultivation. Pearl millet is used to a limited extent in the Southern States, mostly for soiling but has no advantages over the sorghums. The botanical name is Pennisetum glaucum (L.) R. Br. Other names are Pennisetum americanum (L.) Schum., Pennisetum typhoideum Rich., and Penicillaria spicata Willd.

\section{THE SORGHUMS}

The term sorghum includes a number of rather diverse forms all derived from a single botanical species. These forms have been cultivated and selected for different purposes and hence have developed along different lines. Some are cultivated for the sweet juice, from which syrup is made. Others are cultivated for forage, others for the seed. One form called broom-corn is cultivated for the long stiff branches of the inflorescence. The following is a key to the commoner kinds of sorghum.*

30. Pearl Millet. A seed head or spike, reduced from natural size.

* Ball, History and Distribution of Sorghums (U. S. Dept. Agr. Bur. Pl. Ind. Bull. I75. I9Io.) 
Pith juicy

Juice abundant and very sweet............ Sorg o

Juice scanty, slightly sweet to subacid

Panicles cylindric; peduncles erect; spikelets 3 to 4 mm. wide; lemmas awnless............. Kafir.

Panicles ovate; peduncles mostly inclined, often recurved; spikelets 4,5 or $6 \mathrm{~mm}$. wide, lemmas

Pith dry awned . . . . . . . . . . . . . . . Milo.

Panicle lax, 25 to $70 \mathrm{~cm}$. long

Rachis less than I/5 as long as the panicle; panicle umbelliform, the branches greatly elongate

Broom-corn.

Rachis more than $2 / 3$ as long as the panicle

Panicle conic, the branches strongly drooping Shallu.

Panicle oval or obovate, the branches spreading .................... Kowliang.

Panicle compact, Io to $25 \mathrm{~cm}$. long

Spikelets broadly obovate, $2 \frac{1}{2}$ to $3 \frac{1}{2} \mathrm{~mm}$. wide

Kowliang.

Spikelets broadly obovate, $4^{\frac{1}{2}}$ to $6 \mathrm{~mm}$. wide

Glumes grayish or greenish, not winkled, densely pubescent; seeds strongly flattened

Durra.

Glumes deep brown or black, transversely wrinkled; thinly pubescent; seeds slightly flattened . . . . . . . . . . . . . . . . Milo.

The sorghums with sweet juice are known as sugar or saccharine sorghums, or more recently as sorgo. They are used for the production of syrup and for forage. Two well-known varieties are Amber and Orange. In the southern part of the Great Plains region, sorgo is often known as cane. For forage, sorgo is sown or planted thickly in order to produce numerous slender stems that can be cut with a mowing machine.

The sorghums with dry stems or with somewhat juicy 
but not sweet stems are known collectively as nonsaccharine sorghums. Kafir, milo, and durra have become important in the semiarid regions of the area from Kansas to Texas and westward because of their drouth resistance, and are used for forage and grain especially in the localities where dry farming is practiced. A variety of durra that has recently come into prominence is called feterita. A variety of sorghum escaped from cultivation in Louisiana and growing in a semiwild state is called chicken corn.

Common Names.-The common names of the various races and varieties of sorghum are very numerous. Some of these have been indicated in the preceding paragraphs. The general name is sorghum, and the varieties together are generally indicated by the plural, the sorghums. Agriculturists, especially in the Middle West, distinguish saccharine sorghums with sweet juice from the non-saccharine sorghums without sweet juice. Broom corn is grown only for the special purpose of broom-manufacture. The saccharine sorghums or sorgo, such as Orange and Amber, are grown for the production of syrup and for forage but in this country not for grain. In the Middle West when sown for forage, sorgo is often called cane. The most important of the non-saccharine sorghums are Kafir (or Kafir corn) and milo (sometimes called milo maize). Crook-necked varieties of milo and durra are not looked upon with favor because the crooks interfere with harvesting. Feterita is a variety of durra. Sudan grass, a variety distinct from any of those mentioned in the key to the sorghums, is treated separately in a following paragraph. Tunis grass is another dis- 
tinct variety allied to Sudan grass. Both the latter are used for forage. Kafir and milo are used for both forage and grain.

Botanical Names.-Holcus Sorghum L. The name Holcus has been referred to under Johnson grass. The specific name, Sorghum, is of Italian origin and was the name by which it was known in Europe during the Middle Ages. Some botanists include this genus in the large genus Andropogon, in this case, calling it Andropogon Sorghum (L.) Brot. Chicken corn is Holcus Sorghum Drummondii (Nees) Hitchc. (Andropogon Sorghum Drummondii Piper).

Description.--Stems stout, erect, pithy, dry or juicy, sometimes growing to the height of Io feet or even more, annual or in warm countries persisting, but not producing rootstocks; leaves broad, sometimes as much as 2 inches or even more; panicle open or condensed, oval or oblong, the stalk upright or bent in the form of a crook.

Broom corn has an open panicle with long, stiff, naked branches.

Kafir has a dense oblong paniele on an erect stalk, and comparatively low stout stems, mostly 4 or 5 feet tall.

Milo has dense panicles, usually short or ovate, sometimes on curved stalks, the stems usually taller than those of Kafir.

Sudan grass has slender stems and a loose open panicle. This plant looks more like a large Johnson grass but differs in having an annual root without rootstocks.

Durra has compact panicles and strongly flattened seeds. 


\section{SUDAN GRASS}

Sudan grass is a form of sorghum differing from the varieties described in the paragraph on that subject (page 127). It is a slender-stemmed form reaching a height of 5 to 7 feet when grown thickly or to the height of 9 feet or more when grown in rows and cultivated. The stooling of the stems is pronounced, one seed producing 50 to roo stems when there is plenty of room, though under ordinary conditions only a few are formed. In general appearance Sudan grass is more like Johnson grass than the familiar varieties of sorghum, but no rootstocks are produced. The panicle is large and open.

Sudan grass is giving much promise in the warmer portions of the United States. Just how far north it can be used to advantage has not yet been definitely determined. It is sensitive to frost but is a quick grower and will produce a crop during the frostless months, as it requires only 60 to 70 days for maturity. The Maryland Agricultural Experiment Station reports success with this crop. (Md. Agr. Exp. Sta. Bull. 194. 1916.) On account of its quick growth and heavy yield, it is exhausting to the fertility of the soil. Its chief use northward is as a catch hay crop, as is millet. It is valuable for hay and for soiling and is used in the same way as sorgo.

Sudan grass is best sown with a grain drill at the rate of about 15 pounds (of clean seed) in the dry sections or 20 to 25 pounds in the humid sections. If sown broadcast the amount required is one-half to one-third more. The hay can be cut when the plants start to head but a better quality is produced when the heads are in 
full bloom. The hay is cut with a mower and harvested in the same manner as is timothy or other heavy hay but being succulent (especially the stems) requires more time for curing than does timothy. Another method is to use a grain binder and tie in small sheaves, these being set up in small shocks to dry in the field. In the South two cuttings can be secured.

The botanical name is Holcus Sorghum Sudanensis (Piper) Hitchc. It is also known as Andropogon Sorghum Sudanensis Piper. An allied form, Tunis grass (Holcus Sorghum exiguus (Forsk.) Hitchc.; Andropogon Sorghum exiguus Piper) has been tried but seems to be of less value than Sudan grass.

For a full discussion of Sudan Grass see U. S. Department of Agriculture Bulletin I 26.

\section{TEOSINTE}

Teosinte is a coarse succulent grass of Mexican origin, used sparingly in the Southern States as a soiling plant. It is an annual, growing to the height of 4 to 8 feet, branching at the base, producing many stalks with broad leaves. The stalks resemble those of corn but are more slender. At the summit is a tassel similar to that of corn and in the axils of several of the leaves are small ears with protruding silk. The ears consist of several rows of rhomboidal hard seedlike joints, each row surrounded by a covering of husks. Under favorable conditions teosinte produces a large amount of green forage but for a high yield requires considerable moisture. It can be grown to advantage only along the Gulf Coast. Being a tender plant, it will not withstand frost. 
The botanical name of teosinte is Euchlaena mexicana Schrad.

\section{CORN}

Indian corn or maize is primarily grown for the grain but a considerable amount is used for forage, either directly as a soiling crop or incidentally as corn fodder. Throughout the corn-growing region a large amount of green corn is cut and fed to stock upon the farm. Usually this is taken from fields sown for grain-production. Sometimes the seed is sown thickly and the resulting growth, being thin-stalked, is cut with a mower and made into hay.

A large amount of coarse forage is obtained from corn fodder or corn stover. This is a by-product from the corn grown primarily for grain. The corn is cut when it is nearing maturity but before the leaves have lost their nutritive qualities, when the grain is past the milk and is beginning to harden. At this stage is produced the maximum of the combination of grain and forage. The cut stalks are placed in shocks where they are allowed to remain until cured. The corn is then husked out and the fodder stored for use in winter. Or the dried stalks with the ears are run through a machine which husks the ears and shreds the fodder.

Another important forage use of corn is that of silage, taking the lead among plants used for this purpose.

The botanical name of corn is Zea mays $\mathrm{L}$. The origin of corn is uncertain as it is not now found in the wild state. It originated somewhere in America between Mexico and Bolivia, and was cultivated by the aborigines from Brazil to New England before the discovery of 
America by Columbus; it is now cultivated throughout the warmer regions of the world.

\section{THE SMALL GRAINS}

These grasses are ordinarily grown only incidentally for forage, but on the Pacific Coast, because of the absence of forage grasses suited to the conditions, the grains are extensively used for the production of hay, there known as grain hay. About three million tons of grain hay are produced in the states of California, Oregon, and Washington. The grains here used for hay are mostly wheat, barley, and oats, including wild oats.

Wild oats is a common and of ten dominant constituent of the growth upon fallow grain fields. There are two species included under the designation wild oats. The commonest is Avena fatua $\mathrm{L}$. which differs from the cultivated oat, Avena sativa L., in having the florets covered with stiff brownish hairs, while the florets of the cultivated oat are smooth. There is a smooth variety of this, called A. fatua glabrata Peterm., which can be distinguished from the cultivated oat by the strong bent awn and by the easily disarticulating florets. The second species of wild oat is Avena barbata Brot. This differs from the other species mentioned above in having more slender panicle branches, and in having the teeth of the lemma extended into slender awns.

\section{CHESS OR CHEAT}

This is a European species of the genus Bromus which has become a troublesome weed in this country especially in grain fields. It is an erect annual, often stooling at 
the base like wheat, with smooth sheaths, flat blades, an open drooping panicle, and smooth, rather plump, several-flowered spikelets, the florets with short bristles. Though troublesome when growing with grain because the seeds are difficult to separate from those of wheat, it nevertheless is a nutritious forage grass. The only region where it is used for forage on a commercial scale is in the valley of the Columbia River in Washington and Oregon. Bromus secalinus L. is the botanical name.

There is a myth, still current in some localities, that wheat, under unfavorable weather conditions, turns to chess. 


\section{CHAPTER $\mathrm{X}$}

\section{NATIVE FORAGE GRASSES}

THE grazing industry is an important branch of agriculture. As the term is usually applied, it refers to the raising of stock upon large areas of native pasture. Formerly the native pasture was chiefly public land commonly known as range. As time passes the area of public land becomes less and that privately owned becomes greater, the latter usually being fenced. Furthermore the National Forests formerly open to the public are now subject to grazing only under lease. It is not the purpose here to discuss policies or details concerning grazing or the stock industry, but to point out the importance of grasses as a basic element in this industry.

Native pasture or range consists of a great variety of plants. In times of stress, stock may be forced to feed upon many kinds of vegetation that cannot be classed as forage plants, in fact may eat any shrub or herb that is not actually inedible because of spines or prickles, or because of being too woody or fibrous. Of those plants which are eaten from choice, the grasses are by far the most important. The principal grazing areas lie west of the Iooth meridian. Formerly nearly all of the eastern portion of the Great Plains was devoted to stock raising but a large proportion of this region is now devoted to crop raising and to stock raising as a part of general farming. The range region of the western 


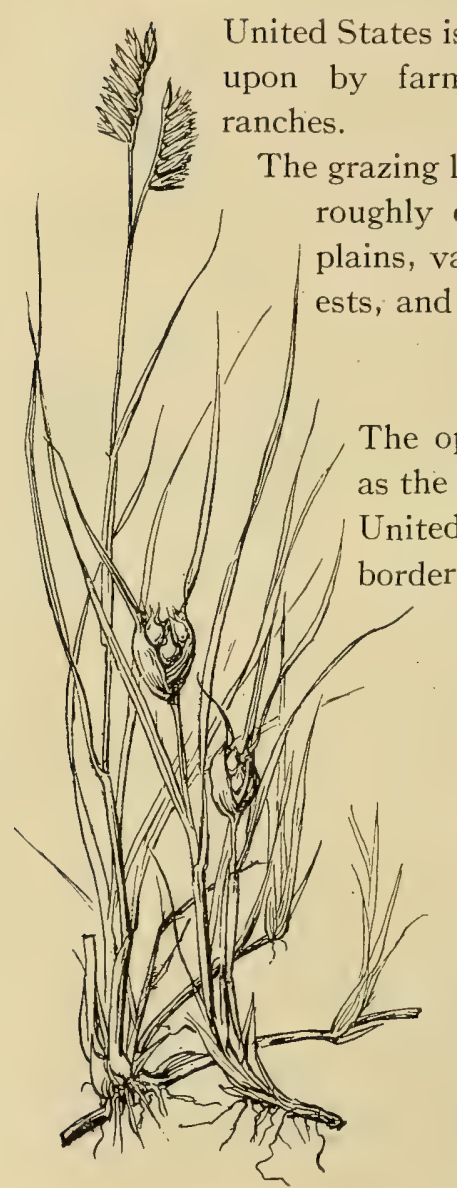

31. Buffalo Grass. Showing a staminate plant at left, with two spikes of flowers; a pistillate plant at right, with two clusters of seedbearing flowers. Seed is produced only by the second kind of flowers.

\section{PLAINS}

The open treeless region known the Great Plains extends in the States from the Canadian to Mexico and from the Rocky Mountains to about the 96th meridian. A large proportion of this is still devoted to grazing. In this region grasses form so large a part of the grazing that the other plants may be disregarded. Over a considerable portion of Texas the meskit tree (Prosopis juliflora) forms an important source of forage, but this region probably should be classified as forest rather than as plain. The grasses of the plains 
are numerous, but three species, buffalo grass, grama grass, and curly mesquite, stand out as being especially important. These are all popularly known on the plains as short grasses, to distinguish them from taller species of the valleys, such as bluestem. In all three species the foliage is short and curly, forming a close covering to the soil. The flower stalks of grama grass rise to the height of several inches.

Buffalo grass (Bulbilis dactyloides (Nutt.) Raf.; Buchlor dactyloides (Nutt.) Engelm.) is a light or grayish green creeping grass that forms a strong firm sod. The flowers are of two sorts, the male or staminate being produced on short erect stems 3 to 6 inches tall, with 2 or 3 short pale spikes or flags, not ing two spikes of flowers.

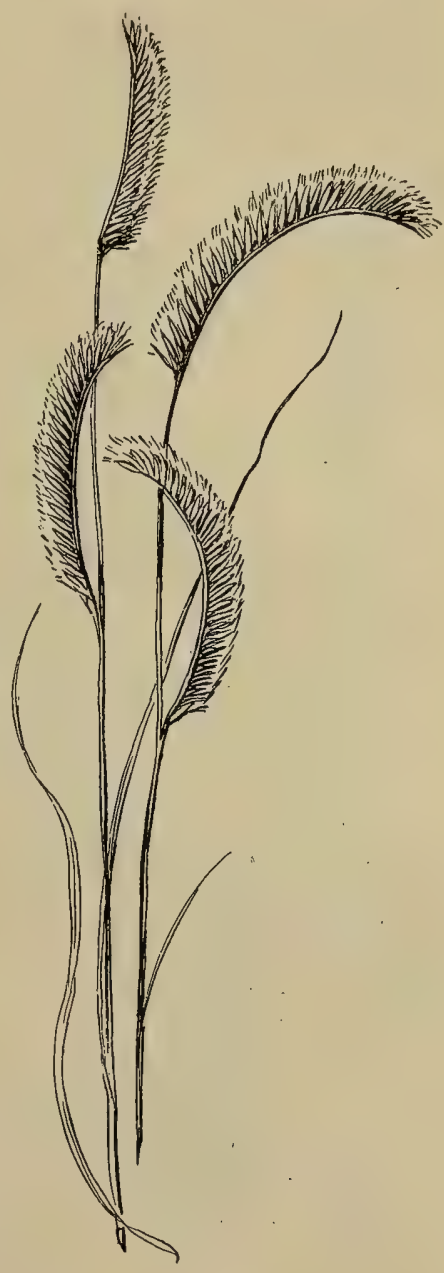

32. Grama Grass. The upper part of two flower stems, each bear- 
over $\mathrm{I} / 2$ inch long, near the top. The female or pistillate flowers (these bearing the seed) are in little green

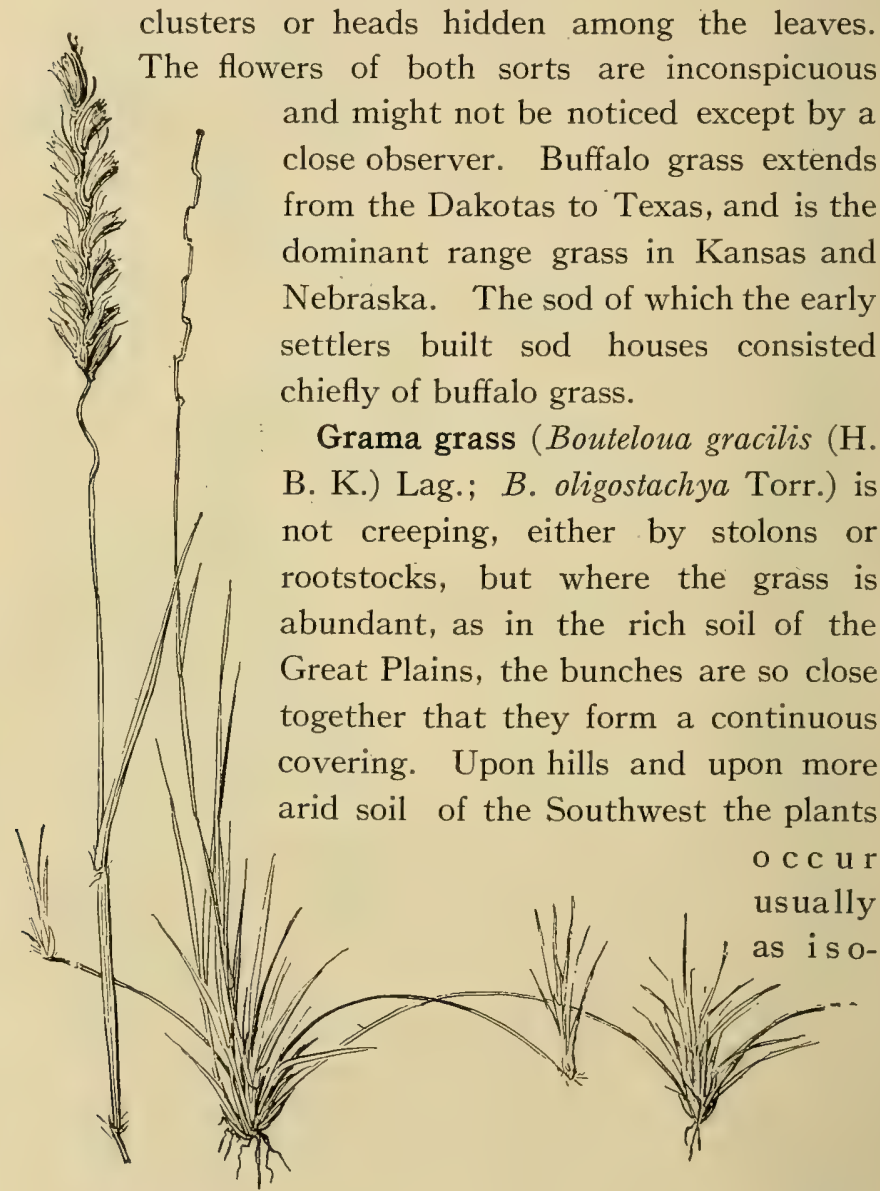

33. Curly Mesquite. An old plant with runners which produce new plants; an old flower stem with a seed head from which the spikelets have fallen. At the left is a young seed head or spike. 
lated bunches. Grama grass resembles buffalo grass in its foliage, but may be readily distinguished by the flower stalks. These rise to the height of several inches or in favorable conditions to as much as a foot and a half. Towards the top are I to 3 spikes or flags, one at the end, the other I or 2 , if present, at intervals of about an inch below. The flags are about an inch long, brownish or purplish in color and attached at an angle, sometimes nearly horizontally. They act as wind vanes, being all blown to the leeward side. Grama grass is found in varying quantities throughout the Great Plains. There is a second species of grama grass called black grama (Bouteloua hirsuta Lag.), to distinguish it from the one described above, called sometimes blue grama. Black grama closely resembles blue grama but is found especially on sterile hills and not usually on the rich open plains. Black grama is smaller and the flags are more fuzzy.

Curly mesquite (Hilaria Belangeri Steud.) resembles buffalo grass. It forms runners by which it spreads and forms a close sod. The flower stalks are usually only a few inches high but may be as much as a foot high. The inflorescence or flowerhead is a close spike an inch or two long. The spikelets are in clusters closely set along a central axis. The spike or cylindric flowerhead is often brownish or purplish, sometimes almost black. Curly mesquite is the dominant grass on the plains of Texas.

\section{VALLEYS}

In this category are placed the open valleys in which forest is absent or confined to the immediate, vicinity of 
the water courses. Forested valleys are classified with humid forests. The valleys support a richer vegetation because of the greater fertility of the soil and because of the greater water supply. They are usually the first part of a region to be occupied by habitation and are the first to be turned from grazing to field crops. Up to the present time, an important part of the grazing areas of the arid and semiarid regions has been supplied by the valleys. Since they contain the chief water supply, the valleys were taken up as claims and are now mostly under private ownership, hence are usually fenced. In so far as these pastures contain the original native vegetation they may be discussed under the subject of ranges. In this discussion will be included both pasture and meadow grasses. In the valleys the richer growth is utilized for the production of hay. The grasses of the valleys are, in the main, different from those of the uplands. The original vegetation has often been increased and sometimes considerably modified by irrigation or flooding. The unwonted water supply has encouraged the growth of those species that are accustomed to moist soil so that sometimes these species have become dominant over large areas. Unfortunately these moisture-loving species may be of inferior forage value. A notable case of this kind is the so-called wire grass of the Rocky Mountain region. This is a species of rush (Juncus balticus L.) and not a true grass. It is now the dominant plant in many parts of Wyoming and adjacent states, where it is the custom to flood the native meadows. The excessive water supply has encouraged the growth of the wire grass and has inhibited the growth 
of the more nutritious grasses. The hay made from wire grass is fairly palatable but is much less nutritious than the original grass-hay of these valleys. There are many species of grasses common in the Mississippi Valley that find their way up to the valleys of the plains. Many of these are the "tall-grasses" mentioned previously, of which big bluestem (Andropogon furcatus Muhl.), little bluestem (Andropogon scoparius Michx.), Indian grass (Sorghastrum nutans (L.) Nash) and switch grass (Panicum virgatum L.) are examples. In the valley of the Arkansas River and other valleys to the southwest, a species of Sporobolus (S. airoides Torr.) is common. Through this region this grass is known as bunch grass, a name that is applied to many other species in various parts of the country. The inflorescence is open and spreading. A related species of Sporobolus (S.Wrightii Munro) is common in the valleys of southern Ari-

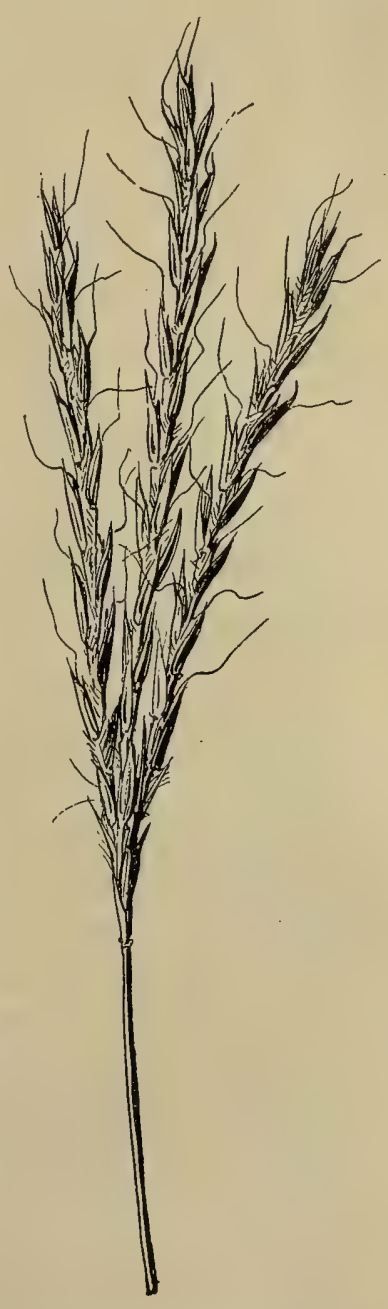

34. Big Bluestem. A head with three spikes of flowers. 
zona and New Mexico, where it is known by the Mexican name of sacaton. This is a vigorous bunch grass 2 to 6 feet high, erect, with long tough leaves and a large open oblong panicle I to 2 feet long. In the valleys to the north, especially in the Great Basin, a species of bluegrass (Poa nevadensis Vasey) is common. In alkaline soil the dominant grass is likely to be salt grass (Distichlis spicata (L.) Greene). . This is a short tough grass with extensively creeping stout wiry rootstocks, short stiff distinctly 2-ranked leaves, and a short narrow whitish flower head. Salt grass is of little value for forage but in the absence of other grasses is grazed by stock. Large areas of the grass are found in the Salt Lake basin of Utah.

\section{DESERTS}

Under this heading are included the arid regions west of the Great Plains. Much of the desert region is more arid than the western part of the Great Plains, but even in cases where the rainfall is about the same, the desert differs from the plain in the lack of a continuous grass covering. The vegetation of the desert varies from almost total absence to a covering of scattered shrubs and small trees. Alkaline deserts may be so strongly impregnated with salt or soda as to be totally lacking in vegetation. These deserts are the basins of former lakes and may still contain shallow lakes at least during the wet season. Such deserts are colloquially known as "slick deserts." Where the soil is less alkaline there may be a growth of grease wood and salt bushes. The later are of value as forage plants. If the soil is not 
strongly alkaline there is always some vegetation even though the rainfall is very low. Areas of drifting sand and of rock are devoid of vegetation, one because of the instability of the soil, the other because of its absence, and not because of the absence of water. In the regions thus far mentioned under deserts there is no grazing.

In a general way the remaining desert areas furnish some grazing at certain periods of the year. Much desert land is excluded from actual use because there is no water supply for stock. Portions of such regions are gradually being brought into usefulness by the boring of wells and the discovery of artesian water supply.

Throughout the region from the Sierra Nevada Mountains to the Rocky Mountains, the plateau is a desert region at the lower altitudes (excluding the vicinity of the streams) with humid forests upon the numerous interspersed mountain ranges. The snow fall, except in the southern part of the region, affords a supply of water for stock during the winter, hence it is customary to range sheep upon the desert in winter and upon the mountains in summer. The forage upon the desert in winter is chiefly shrubs and coarse perennials that are not grasses.

In southern California, Arizona, and New. Mexico annual plants, including several small annual grasses, are important sources of forage following the short rainy season. In the eastern part of this region the rain comes mostly in the summer, hence there is a short period of summer grazing. In the western part the rains come in the winter, with a corresponding winter grazing season. There is an intermediate region where the seasons over- 
lap and there may be rains in both summer and winter, followed by two grazing seasons.

The northern portion of the Great Basin is a vast plateau, the dominant plant of which is the sage brush (Artemisia tridentata). This region is often referred to as sage brush plains. It is scarcely a desert but is so classified here because it is arid or semiarid. It affords many species of grasses that furnish forage during the spring and early summer. Chief among these are certain native species of bluegrass (Poa Sandbergii Vasey, and several other species of Poa).

The foothills of the Pacific Coast region furnish excellent forage after the winter rains but become brown and sere during the summer. One of the most important native species is California bluegrass ( $\mathrm{Poa}$ scabrella Benth.). This region has been invaded by a host of introduced annuals which are driving out the native grasses and themselves furnish an inferior forage. These annuals are grazed during the early growth before the seeds are produced. The most conspicuous of these intruders are several kinds of brome grass (species of Bromus) and wild barley (species of Hordeum).

\section{HUMID FORESTS}

In general the forests occupy the mountain ranges, except the upper part of the higher peaks. The timber line is approximately i $\mathrm{I}, 000$ feet altitude in the southern mountains and about 6,ooo feet at the north. The lower limit of the forest depends upon the rainfall. In the eastern Rocky Mountains the forest meets the plains, in the Great Basin it meets the desert and sage brush plains. 
In the Pacific Northwest the forest originally occupied most of the region from the Cascade Mountains to the coast. The dense humid forest furnishes no grazing grasses of importance but the more open forest of the upper mountains may be carpeted with grass. An important grazing grass of the mountains of eastern Washington and eastern Oregon is pine grass (Calamagrostis rubescens Buckl.). This is a fine-leaved bunch grass with a contracted, oblong, or cylindric flower head. Another important grazing grass of the northwest is "bunch grass" or mountain fescue (Festuca idahoensis Elmer), a grass with slender rough stiff leaves in a large basal cluster and a small somewhat open fewflowered panicle. There are also many species of Poa or native bluegrass.

The plateau of northern Arizona and adjacent regions is covered with open forest and is here classified as forest, though it is a semiarid region. Another species of Festuca ( $F$. arizonica Vasey), a bunch grass resembling $F$. idahoensis, but often conspicuously bluish, is common and is an important part of the forage.

\section{MOUNTAIN MEADOWS}

Where the mountains are high enough to extend above tree line, there are areas of grass land that furnish grazing during the summer as the snow retreats. These mountain meadows contain many species of grasses, few of which have distinctive common names. One species, on account of its resemblance to the cultivated timothy, is called mountain timothy (Phleum alpinum L.). Mountain bunch grass (Festuca viridula Vasey), common in 
mountain meadows in this region, is a smooth erect perennial with acute but awnless florets.

\section{WILD HAY}

Large quantities of wild hay are put up in the West for use upon the farm or ranch. In the arid and semiarid regions this hay is procured from the valley lands that can be irrigated or flooded, or from naturally moist land along the water courses. The grasses that furnish the hay are the species mentioned previously as growing in the valleys. Commercial wild hay is produced in large quantities in the United States lying east of the Rocky Mountains and north of the Cotton Belt. By commercial hay is meant that which is sold upon the market, as distinguished from that which is consumed upon the farm or ranch. The wild hay may be classified as prairie hay, marsh hay, and salt marsh hay.

Prairie hay is produced from the prairie grasses, the most important of which are big bluestem (Andropogon furcatus), little bluestem (Andropogon scoparius), Indian grass (Sorghastrum nutans), and switch grass (Panicum virgatum). Prairie hay is very nutritious and is valued highly, especially for livery horses. The amount of prairie hay produced is constantly decreasing as the prairie is converted into farms. The region now producing prairie hay is the eastern portion of the Great Plains from Arkansas and Oklahoma to the Dakotas.

Much hay is produced in the drier portion of the Great Plains from western wheat grass (A gropyron Smithii), a harsh erect bluish grass with creeping rootstocks and a slender wheat-like head. It grows especially in soil that 
is slightly alkaline. This grass is sometimes called bluestem and bluejoint but should not be confused with the prairie bluestem mentioned above (Andropogon furcatus), nor with the marsh bluejoint mentioned later.

Marsh hay is produced from areas too moist for field crops, and too moist to be classed as prairie. These areas are moist meadows rather than marshes. They may be fairly dry during a part of the season but somewhat marshy during the wet season. Hay cannot be cut from these areas if the soil is actually marshy during the haying season. Marsh hay is produced on a commercial scale only in the North, from the Dakotas to Wisconsin. In some localities flat wooden shoes are placed upon the horses' feet to enable them to traverse the soft ground.

Most of the marsh hay is produced from two species of grass, marsh bluejoint (Calamagrostis canadensis (Michx.) Beauv.) and reed canary grass (Phalaris arundinacea L.).

Salt marsh hay is produced from saline marshes or meadows along the Atlantic Coast chiefly from Maine to New Jersey. The common marsh grasses of the coast are used, consisting especially of the smaller cord grass (Spartina patens (Ait.) Muhl.) and black grass, a kind of rush. (Juncus Gerardi Loisel.) The hay is mostly too coarse to make good forage but is used extensively for packing and for stable bedding.

\section{CULTIVATING NATIVE GRASSES}

Many experiments have been tried to utilize the native grasses as a cultivated crop. The only species that has 
been introduced into cultivation on a commercial scale is slender wheat grass (Agropyron tenerum Vasey). This is an erect bunch grass growing throughout the West especially in the Northwest. The seed head is slender and beardless, resembling a very slender, drawn-out wheat head.

The chief difficulties in the introduction of the wild grasses are connected with economic seed production. On page 53 are enumerated some of the reasons that make timothy an important forage grass. In general wild grasses do not conform to the timothy standard.

Big bluestem is an excellent forage grass and produces hay of the best quality, but efforts to introduce it into cultivation have not succeeded because the seed is produced in small quantity and is not easily handled.

There is a persistent demand from ranchmen for a grass which will produce grazing or hay upon arid or semiarid land. This demand, unfortunately, is not likely to be gratified. For grazing purposes the native grasses are usually producing all the forage possible under the prevailing conditions. Through a long series of centuries these grasses have adapted themselves to the climatic conditions, and are producing a maximum for those conditions. In seasons of maximum rainfall they yield abundantly; in seasons of minimum rainfall they produce sparsely, merely maintaining their existence. The perennial grasses, which constitute the bulk of the grazing except in certain desert regions (see page I35), maintain themselves, but do not spread or occupy new soil except under unusually favorable conditions. Under natural conditions these grasses depend upon these 
exceptionally favorable seasons to utilize their seed for the production of new growth. Plants introduced from foreign countíies can do no better. It is an idle quest to seek for a grass that can be sown by a man on horseback on a depleted range, to rejuvenate it. The best way to rejuvenate a worn-out or overgrazed range is to give it a rest, taking off the stock and giving the native grasses a chance to recuperate. Astonishingly few grasses have been introduced into successful cultivation, and these nearly all in humid regions. First there are the European grasses introduced in earlier times and adapted to normal humid agricultural conditions. These are timothy, redtop, orchard grass, rye grass, bluegrass, the various fescue grasses and several others of minor importance. But as a result of recent experiments and active search for grasses by the United States Department of Agriculture and the Experiment Stations, only a few species have been proved of value. These are brome grass, and slender wheat grass to a limited extent, found suited to the northern part of the Great Plains, Sudan grass (and other varieties of sorghum, such as Kafir corn and milo, see page I26) for the southern part of the same region, Natal grass for a limited area in Florida, and possibly Rhodes grass and Napier grass for the southwest.

In general, considering the grasses of the world, few species meet the qualifications, such as favorable seed habits, for successful cultivation. All the grasses now in cultivation in the United States (with the single exception of slender wheat grass) have been introduced from 
other countries where they were already in successful cultivation.* We have not a single case of a grass from another country having been introduced into successful cultivation here, that was not already in use in the country from which it came. Seed has been gathered all over the world from hundreds of wild species and tested by our Department of Agriculture and the Experiment Stations, but thus far none has been proved to be any better adapted to our conditions than those already in use. The search is being continued and such species may be found but we must not entertain exaggerated expectations. Much more success has resulted from a study of the species now in cultivation in the various countries of the world. By testing these throughout our country, additional species, or improved varieties, may be found that are adapted to certain conditions or regions where now none such are in use.

* St. Augustine grass and possibly carpet grass are native species now cultivated but the seed is not a commercial product, the plants being grown from cuttings. 


\section{CHAPTER XI}

\section{OTHER ECONOMIC GRASSES}

BEsides the major use of grasses, the production of food and of forage, there are several minor uses, the most important of which will be considered under the following heads: lawns, ornamentals, sandbinders, fiber grasses, sugar-producing grasses.

\section{LAWN GRASSES}

A lawn is a small area of grassland in the vicinity of a residence or other building, the grass forming a sod and being kept cut short. It is maintained for its own beauty or for its value in the composition of a pleasing landscape. Larger areas or those not in the vicinity of buildings are usually more properly classed with parks. As a rule a lawn is composed primarily of grass but under conditions not favorable to the growth of grass other plants have been utilized. These cases are so few that they need not here be considered.

The chief characteristics of a good lawri are a uniform growth of grass of fine texture and pleasing color, forming a firm even sod. To secure uniformity of texture and color the lawn must consist of a single species. To form a firm even sod it is necessary that the grass should spread by means of rootstocks or stolons. Fine bunch grasses such as the fescue grasses will form a pleasing lawn if the conditions of growth are ideal and the planting and subsequent care are of the best. But these condi- 
tions are seldom entirely met, consequently these grasses are not often used alone for a lawn.

The only grasses which perfectly meet the requirements of a lawn are Kentucky bluegrass and the bent grasses. The conditions favorable to the growth of the former are prevalent over a much wider area, for which reason Kentucky bluegrass may be said to be our best lawn grass. Bermuda meets all the requirements of a lawn grass except that of color. The light green is not so pleasing to the eye as the dark green of bluegrass. St. Augustine and carpet grass are too coarse for-an ideal lawn grass. Rye grass and the fescue grasses do not form rootstocks or stolons and hence do not produce a firm sod. The former, much used for parks, is rather coarse for a lawn.

Mixtures of grasses are often recommended for lawns. The chief objection to mixtures is that the texture and color of the lawn are not uniform. The different species of grasses (and white clover) differ in color and fineness of foliage. If the species were mixed on the lawn with perfect uniformity, the lawn itself would appear uniform in texture and color. But in practice this is impossible of accomplishment. The different species sooner or later appear as spots or areas and these destroy the uniformity.

On the other hand, mixtures have this important advantage, that a more complete and uniform stand of grass can be obtained. Each species of the mixture thrives on the soil best suited to its growth, hence the soil is likely to be more completely covered. Mixtures are especially to be recommended for parks and other 
large areas. Conditions must govern the choice between mixtures and single species. If an ideal lawn is desired and if it is possible to provide ideal conditions, then a single species should be chosen. The single species to be used would depend upon the locality. It would be Kentucky bluegrass wherever that species can be successfully grown. It would be Rhode Island bent in the North Atlantic States, Bermuda in the South, St. Augustine or carpet grass along the coast of the Southern States. But if ideal conditions cannot be provided, either because of the expense involved or because of the natural soil conditions, it is advisable to sow mixtures with the hope that the unfavorable conditions may be thus partly neutralized.

The reader is referred to the chapter or paragraph on each species of grass for information concerning its use as a lawn grass. Under the chapter on bluegrass will be found directions for making a lawn. In general it may be stated that an ideal lawn requires great care in the preparation of the soil. It should be uniform, welldrained, and fertile. It should be put in a condition of perfect tilth. It often requires a year's preparation to place the soil in a perfect state for the reception of the seed. If the soil is not naturally fertile it should be enriched with barnyard manure, well rolled, and free from noxious weeds. An important item also is the use of the best grade of seed obtainable (see page 37 ).

\section{ORNAMENTALS}

Several species of grasses are used for ornament. A few species are grown for the inflorescence which is 
utilized in making dry bouquets. The chief use, however, is as a border plant in gardens or as clusters in lawns. In both cąses the attractiveness depends more on the foliage than on the inflorescence. Many of these ornamental grasses have variegated varieties. In this chapter will be mentioned only the more common grasses grown out of doors in the United States.

Ribbon Grass.-Gardener's garters. (Phalaris arundinacea L.) This is probably the most commonly grown ornamental grass. It is one of the old-fashioned species found especially in old gardens and around old homesteads in the northern and eastern states. Ribbon grass is a tufted perennial 2 or 3 feet high, the leaves striped with white and green. Horticulturally it is variety picta $\mathrm{L}$.

Plume Grass (Miscanthus sinensis Anderss.).-This large tufted perennial is grown in the warmer portion of the country, forming a large basal cluster 4 to 5 feet high. The flower stalk rises a short distance above the leaves and bears a fan-shaped inflorescence 6 to 12 inches long, consisting of numerous slender woolly, whitish or tawny branches. There are varieties with banded leaves and with striped leaves. Also known as Eulatia japonica Trin.

Pampas Grass (Cortaderia argentea (Nees) Stapf).This resembles plume grass in having a large cluster of long narrow leaves. The flower stalk rises to a considerable distance above the leaves, being as much as I2 feet high, and bears an oblong rather dense very woolly, white or pink inflorescence or "plume." The plumes are used for interior decorations, for which 
purpose they are often artificially colored. Pampas grass is grown on a commercial scale in southern California, the plumes being supplied to the trade. Also known as Gynerium argenteum Nees.

Giant Reed (Arundo Donax L.).- This very large grass is grown only in the warmer portions of the United States. The stems may grow to the height of Io or I2 feet or even more. The leaves are broad like those of corn, being on the main stems 2 or 3 inches wide and a foot or two long. The base is broad and partly clasping and at the juncture of the sheath and blade presents a lighter colored zone of a somewhat cartilaginous texture. The leaves are distributed rather evenly along the stem in two distinct rows. The large panicle is a plume a foot or two long.

Fountain Grass (Pennisetum Ruppelii Steud.).-This is becoming rather common in the parks of our large cities. It is a slender perennial 2 or 3 feet tall, with a pink or purple feathery head, 4 to 8 inches long. Fountain grass is used as a border plant or as a zone around the base of a group of larger plants.

Bamboos.-Bamboos are grown for ornament in the parks and residential grounds in California and in the East from Florida to Maryland. With their slender branches and feathery foliage they form graceful clusters. The leaves are broad in proportion to their length and are narrowed at the base into a short stalk or petiole. The blades are usually not more than 3 to 6 inches long and half an inch wide. The species most commonly cultivated are Arundinaria japonica Sieb. \& Zucc. with round (cylindric) branchlets, and species of Phyllo- 
stachys with the branchlets flattened on one side. The bamboos above mentioned form masses with numerous slender stems thickly covering the ground and rising to a height of 6 to 20 feet. The common bamboo (Bambos Bambos (L.) Wight; Bambusa vulgaris Wendl.) is grown in southern Florida and southern California. The stems of this grow to a height of 50 to 80 feet and the base of the stem may be 4 to 6 inches in diameter.

\section{SAND BINDERS}

The term sand binder is applied particularly to plants that are able to hold the surface of drifting sand and are used on the bare hills of sand known as shifting or moving sand dunes. Such dunes are found in the vicinity of sandy seacoasts and great lakes and along our larger rivers especially in arid regions. Much has been done in Europe to reclaim these barren sand dunes but in this country such work has been done on a large scale only on Cape Cod, Massachusetts, Golden Gate Park, San Francisco, and in a few minor localities along the Pacific Coast, the Columbia River in eastern Oregon, and the shore of Lake Michigan. The only grasses found satisfactory for this work are the beach or marram grass (Ammophila arenaria (L.) Link) a native of the seacoast of Europe and A. breviligulata Fern. of North America from New England to North Carolina and along the Great Lakes. To protect an area of drifting sand, pieces of beach grass with rootstock attached are planted a foot or two apart. Full information on the subject of sand binders and reclaiming sand dunes will be found in two bulletins from the United States Department of 
Agriculture, Bureau of Plant Industry, no. 57, entitled, Methods Used for Controlling and Reclaiming Sand Dunes; and no. 65, entitled, Reclaiming of Cape Cod Sand Dunes.

\section{FIBER GRASSES}

Most of the vegetable fibers are obtained from such plants as cotton, flax, hemp, jute, manila hemp, and sisal hemp, grasses furnishing but little. The only fiber obtained from grasses is esparto or alfa, which is produced by two species growing in Spain and North Africa (Lygeum Spartum L. and Stipa tenacissima L.). A coarse fiber for making scrubbing brushes is obtained from the roots of a Mexican grass (Epicampes macroura Benth.). Inquiries are sometimes made as to why some of our native grasses are not used as a source of fiber. Many of our grasses contain fiber of good quality but at present the cost of harvesting is so great that they cannot compete with the fibers now in use. Some of them may be used for paper-making when available in sufficient quantity and when the demand for paper-making material becomes imperative. Crex, advertised as grass rugs, is produced from a kind of sedge (Carex species) and not from a grass.

\section{SUGAR-PRODUCING GRASSES}

The sugar supply of the world is produced chiefly from two plants, the sugar cane and the sugar beet. A small amount is produced from sorghum. Sugar cane is a large grass somewhat resembling corn and sorghum. Sugar is made from the juice of the stem. The plant is grown at low altitudes in all tropical countries where sufficient 
water is available, either from the rainfall or from irrigation. It is propagated by planting pieces of the stem. In the tropics the sugar cane flowers but produces only a small quantity of seed. It is from the seed that new varieties are originated. The flower head of the sugar cane is a huge feathery plume. The botanical name is Saccharum officinarum L. Most of the sugar cane in the continental United States is grown in Louisiana. Sugarproduction is a very important industry in the dependencies of the United States, the Hawaiian Islands, Porto Rico, and the Philippines.

In I900 Europe produced about 4,000,000 tons of beet sugar which was one-third more than the total world production of sugar from the cane. The production of sugar in Louisiana in 1900 was 132,000 tons as compared with 650,000 tons in Java and 440,000 tons in Cuba, two important sugar producing countries.

Sugar is produced also from saccharine varieties of sorghum or sorgo (see page I26), but nearly all the product is used for syrup. The syrup industry is mainly confined in the United States to the region from North Carolina to Kansas. 


\section{CHAPTER XII}

\section{WEEDY GRASSES}

Troublesome grasses may be divided into perennials and annuals. Perennial grasses do not become aggressive weeds unless they possess running rootstocks. By means of these vegetative organs they spread and maintain themselves. They are difficult to eradicate because the rootstocks cannot be completely removed from the soil except by persistence and care, and any pieces allowed to remain send up new shoots, these forming centers of growth for a new attack.

The three most common and important weedy perennial rootstock-bearing grasses are Bermuda, Johnson grass, and quack grass. The first two are discussed in the paragraphs devoted to these as forage grasses (Bermuda page 73, Johnson grass page 86). Quack grass or couch grass (Agropyron repens (L.) Beauv.) is an Old World species, now common in the Northeastern States. It is an erect grass 2 or 3 feet high with flat leaves $\mathrm{I} / 4$ to $\mathrm{I} / 2$ inch wide and a narrow head resembling a slender head of wheat. The spikelets are more or less bristlepointed (or bearded as it would be called in wheat). The rootstocks are slender and inclined to be yellowish as is the base of the stem. The grass is a great pest in meadows and fields, but nevertheless can be utilized for forage when abundant. 


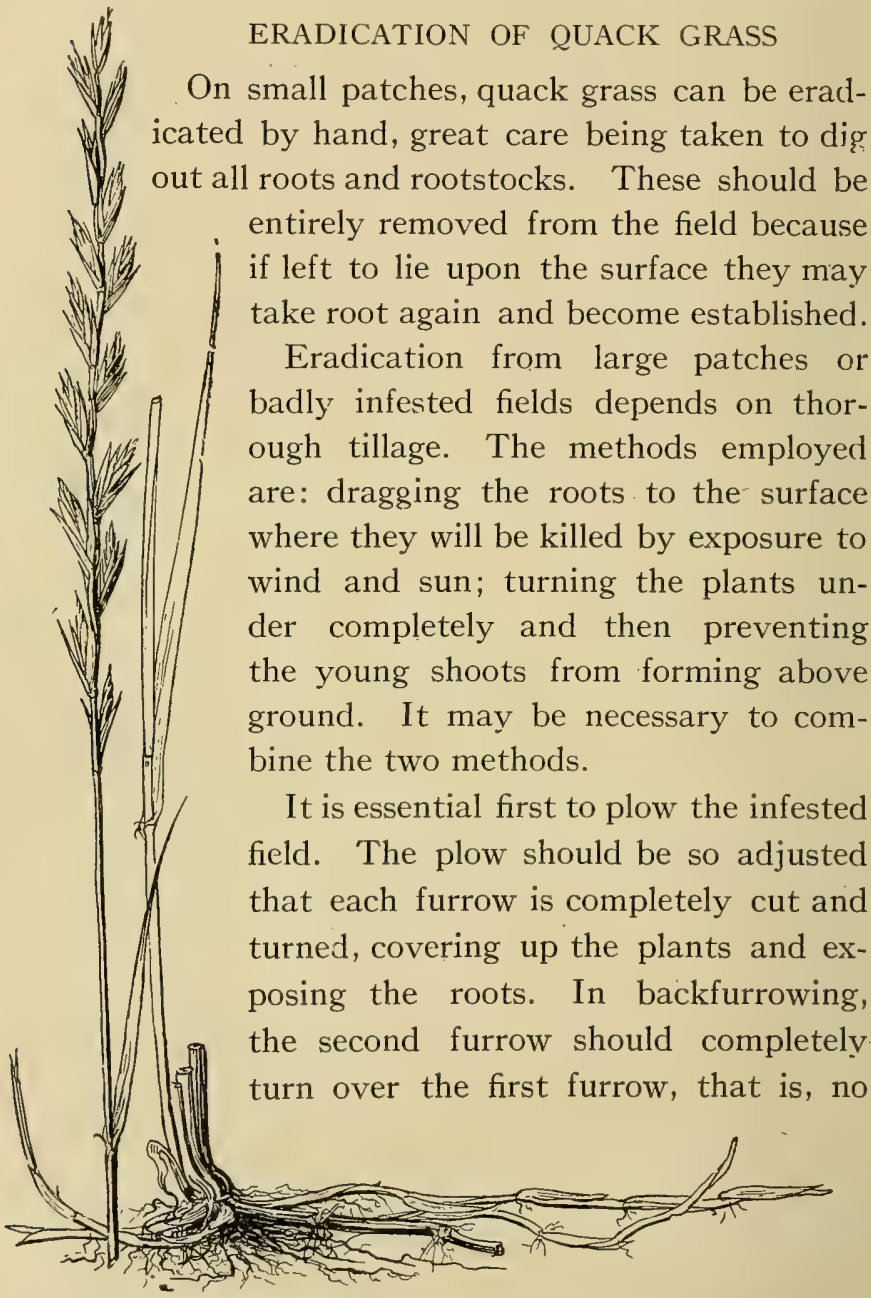

35. Quack Grass. A seed head or spike, and a base showing the vigorous rootstocks by which the grass spreads. 
sod should be left uncut anywhere. Afterwards it is well to disk the field both ways to pack the soil. The plowing and disking greatly reduce the vitality of the grass but do not entirely destroy it. The complete destruction must be done by subsequent tillage through one or more years. In order not to lose the use of the land during this time it is best to plan a rotation of crops suited to the locality. Plowing in August, allowing to lie fallow, and plowing again in late fall, greatly facilitates the destruction the following year. A smother-crop like buckwheat or millet is often efficacious in killing out the pest the next season, especially if there has been harrowing or other culture in the spring before these crops are planted. If a cultivated crop, such as corn follows the plowing, careful tillage with some hand work will usually completely eradicate quack grass.

Nut grass (Cyperus rotundus) is a sedge and not a true grass. It is a common weed of lawns and fields in the Cotton Belt. Nut grass has 3-ranked leaves and propagates by corms or tubers, the so-called nuts. These corms are about $\mathrm{I} / 2$ inch long, somewhat ovoid or oblong, dark brown, and are connected with the main plants by slender rootstocks. The corms may be buried a few inches or even as much as a foot. The plant cannot be eradicated by cutting off the tops. It is necessary to plow up the ground and carefully remove all the corms, or the infested portion can be planted to some shading crop, such as cowpea, and the nut grass smothered out. 


\section{ANNUAL WEEDS}

The annual weedy grasses are numerous and often troublesome. In general, annual grasses germinate in the spring and become prominent in the summer and autumn. Some, especially in the warmer parts of the country, germinate in the fall, live over winter as small tufts, and ripen their seed the following spring. In fields annual grasses can usually be kept in subjection by the ordinary methods of cultivation. In grain fields, meadows and lawns other methods must be used. Clean cultivation the preceding year, and the use of clean seed will usually prevent the growth of a damaging amount of weeds in grain fields. The same is true of meadows and pastures but any lack of vigor in the forage grass, due to a poor stand or a subsequent dying out, invites the encroachment of weeds. A badly infested meadow or pasture should be broken up and reseeded. It is a waste of time to attempt to coddle such a field into good condi- tion. Weedy lawns are discussed in another place (page 65). The common annual weedy grasses are mentioned below.

Crab grass (Syntherisma sanguinalis (L.) Dulac and sometimes also S. ischaemum (Schreb.) Nash).-Plants spreading, in vigorous specimens becoming 3 or 4 feet in diameter, some of the parts often showing a purplish color, the sheaths covered with spreading hairs, the blades flat, rather short, the flower head consisting of several slender spikes, 3 to 6 inches long, radiating from the top of the stem or from near the top. The spreading stems may produce roots from the nodes, the plant 
forming a clinging mat. Crab grass is found throughout the Southern States and extends less abundantly into many of the Northern States. It is rare in the Western

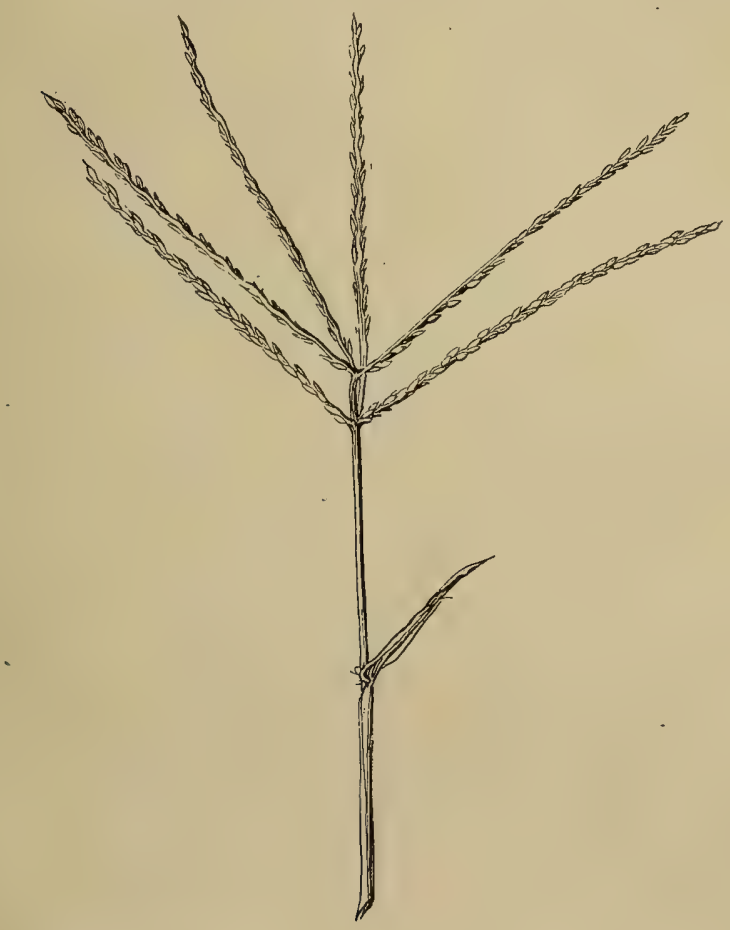

36. Crab Grass. The upper part of a flower stem with six spikes of flowers.

States. Crab grass is a good forage plant in the South and is not infrequently utilized for hay. The seed is not sown but volunteer growth is used. The less common Syntherisma ischaemum is distinguished by its smooth sheaths. 
Brome grasses (species of Bromus).-There are several species of brome grasses abundantly introduced on the Pacific Coast. These germinate in the spring, cover the foothills with green and by midsummer ripen their seed, and present a desolate waste of brown. These brome grasses are distinguished by the several-flowered, usually awned spikelets, that at maturity easily break up into the separate bristle-pointed florets or fruits. Chess or cheat is a kind of brome grass (see page I33).

Barley grasses (species of Hordeum).- Two annual species are common on the Pacific Coast under the same conditions that favor the brome grasses. They are low bushy-branched plants with close oblong strongly bearded heads an inch or two long. One of these species ( H. Gussoneanum Parl.) has a cylindric head that'does not break up at maturity. The other, more common and troublesome ( $H$. murinum L.), has a flattish head which breaks up at maturity into sharp-pointed joints. The long awns or bristles and the joints are strongly roughened, making the fruit (or so-called seeds) a great nuisance. They work their way into clothing, into wool, and still worse into the noses and into the lining of the mouths of animals. This species extends into the Great Basin where it is a troublesome weed in alfalfa fields. It is called foxtail in many parts of the West.

A perennial species of Hordeum ( $H$. jubatum L.) is troublesome in the Rocky Mountain and Great Basin regions. This is called squirrel-tail grass and in some places foxtail. The species may be distinguished by the feathery oblong or cylindric head, turning white at maturity, and the numerous very slender wide-spreading 
awns or bristles an inch or two long. These heads break up and behave in the same manner as barley grass described above. Squirrel-tail grass is troublesome in alfalfa fields and in irrigated meadows. The pieces of the heads with the spreading beards are blown about sometimes in great quantities. The species has extended eastward and is locally abundant as far east as Illinois.

Two other species of Hordeum, one annual (H. pusillum Nutt.) the other perennial ( $H$. nodosum L.), are often abundant in open ground, but are not serious pests. They have small cylindric heads with short. upright bristles. The heads break up into joints. These species are usually only a few inches to a foot high.

Foxtail (species of Chaetochloa. See page I22).-The two common species in the Northeastern States are green foxtail ( $C$. viridis (L.) Scribn.), with a green head slightly narrowed above, and yellow foxtail (C. lutescens (Weigel) Stuntz, C. glauca of authors) with a somewhat long yellow head that is not narrowed above. These grasses are often abundant in neglected fields but are easily eradicated by culture methods. In the South, especially in Florida, there is a perennial species ( $C$. geniculata (Lam.) Millsp. \& Chase) that closely resembles yellow foxtail.

Sandbur (Cenchrus pauciflorus Benth.). This wellknown annual grass is common on sandy soil throughout the eastern half of the United States. The prickly burs with backwardly roughened spines are very troublesome. In the South a second species ( $C$. echinatus L.) is common. The burs of this are scarcely so hard as those of the other. Both species are also known as bur grass. The first has been called C.caroliniana. 
Species of minor importance.-Several species of annual grasses are common throughout many of the Eastern States but do not in general become troublesome weeds in fields. They are especially found in waste places, vacant lots in towns, along roadsides, and in neglected spots on farms. Usually they are not very difficult to eradicate. Tickle grass (Panicum capillare L.), smooth panicum ( $P$. dichotomiflorum Michx.), barnyard grass (Echinochloa crusgalli (L.) Beauv.), goose grass (Eleusine indica (L.) Gaertn.), stink grass (Eragrostis cilianensis (All.) Link) are examples of this group.

Wild oats (Avena fatua L.).-This species is especially abundant on the Pacific Coast where it frequently appears in fallow fields and grain fields after harvest. It is also found under the conditions that favor the brome grasses. Wild oats closely resemble the cultivated oat but differs in having a strong bent awn or bristle on the back of each floret and in having the florets covered with bronze colored hairs. This is an excellent forage grass and is extensively utilized in the production of grain hay (see page 23). A second species, A. barbata, is becoming common in many places.

\section{WEEDS UPON THE RANGE}

There are several native species of grass that might be considered weeds upon the range but only two kinds are worth mentioning here. Both are pests at maturity when the seed is being scattered. They are perennials.

Dog-town grass (species of Aristida, chiefly $A$. longiseta). - This is common on the Great Plains. It has received the name of dog-town grass because it is usually 
found around the burrows of prairie dogs. It readily occupies any new soil such as fire guard furrows and - roadsides. Dog-town grass is an erect bunch grass with numerous short leaves at the base and a flower stalk a few inches to a foot high, bearing rather few spikelets. The florets or seed are tipped with three slender spreading awns or bristles. When ripe these seeds break away and are blown in quantities before the wind. The point (base) of the seed is hard and sharp, the three horizontally spreading bristles are I to 4 inches long. The wind blows these seeds point forwards and they stick into clothing, and into the coats of animals.

Wild barley, wild rye (species of Sitanion).-This is an erect tufted perennial usually about a foot high. The flower head is close and bristly, somewhat resembling barley, rye, and bearded wheat. At maturity the oblong head breaks up into joints, each joint bearing a sharp point at base and several spreading bristles $I$ to 3 inches long. Before breaking up, the head may become detached from the plant and blow about. The beards or bristles are backwardly roughened so that the sections penetrate clothing and readily work their way inward. These seeds are troublesome and even dangerous to stock as they work their way into the mouths, nostrils, and eyes of grazing animals. This kind of wild barley is found widely distributed west of the Iooth meridian. 



\section{INDEX}

Where several references are given, principal entries are in heavyface type.]

Agropyron repens, I59. Smithii, 146. tenerum, II $4, \mathrm{I}_{4} 8$.

Agrostis alba, 80. var. vulgaris, 95 .

canina, 95 .

capillaris, 94 .

palustris, 79 .

stolonifera, 95 .

tenuis, 95 .

vulgaris; 95 .

Alfa, 157 .

Alfalfa, statistics of, 6,8 .

Alopecurus pratensis, I 18 .

Ammophila arenaria, 156. breviligulata, I 56 .

Anastrophus compressus, 107.

Andropogon furcatus, I4I.

halepensis, 89 .

scoparius, I4I.

Sorghum, I 29.

Drummondii, I29.

exiguus, I3I.

sudanensis, I3I.

Anthoxanthum odoratum, I03.

Arid region, $\mathbf{r}$.

Aristida longiseta, I66, 167 .

Arrhenatherum avenaceus, Ioo. elatius, roo. var. bulbosum, I00.

Artemisia tridentata, I44.

Arundinaria japonica, I 55 .

Arundo Donax, 155.

Australian brome grass, 107.

Avena barbata, I33, I66.

elatior, I00.

fatua, I33, I66.

glabrata, I33.

sativa, 133 .

Axonopus compressus, 107.
Bahama grass, 75 .

Bamboos, I55, I 56.

Bambos Bambos, I 56 .

Bambusa vulgaris, 156 .

Barley grasses as weeds, 164 .

wild, injurious weeds, I44, I67.

Barnyard grass, 125, 166.

Beach grass, 156 .

Bean, velvet, I3.

Bent, carpet, 92. seed of, 93 .

Bent grass, 92.

for lawns, I 52, I 53 .

seed of, 93 .

Rhode Island, 92, 93, 94. seed of, 93 . velvet, 93,95 .

Bermuda grass, 1.9, 20, 70, 74 . eradication of, 73 .

giant, 73,76 .

lawn, for, 72, I $52, \mathrm{I} 53$.

pasture, for, $7 \mathrm{I}$.

planted from cuttings, 72 ,

73.

region, I3.

weed, as, 159 .

Billion-dollar grass, I25.

Black grass, 147 .

Bluegrass, 13.

botanical name of, 70 .

California, I 44 .

Canada, roo, ror.

Canadian, I0I.

English [Canada] ror, [meadow fescue], 85 .

Kentucky, I9, 58, 68. description of, 67 . lawns, for, 60,152, I 53 .

pasture, for, 59 . 
Bluegrass seed, 40, 66 . weed, as, 67 . region of Kentucky, 19.

Texas, II 4 .

Bluejoint, I 47 . marsh, 147 .

Bluestem [western wheat grass], I 47.

big, I4I, I48.

little, I4I.

Bouteloua gracilis, 138 .

hirsuta, I 39.

oligostachya, 138 .

Brome grass, I4, 89, 90. annual weeds, I 44, I64.

Australian, I07.

description of, $9 \mathrm{I}$.

Hungarian, 91.

Schrader's, I07. seed, 40.

Bromus inermis, 9I. secalinus, 134 . unioloides, 107.

Broom-corn, I28, 129.

Buchloë dactyloides, I 37 .

Buffalo grass, I36, I37, I38.

Bulbilis dactyloides, I 37 .

Bunch grass, I4I, I 45. mountain, I 45 .

Bur grass, 165 .

Calamagrostis canadensis, I47. rubescens, I 45 .

Canada field pea, 9.

Canary grass, reed, $\mathbf{I} 47$.

Cane, I4, I27.

Capriola Dactylon, 76 . var. maritima, 76 .

Carib grass, I 18.

Carpet bent, 6o, 63, 92, 95 . seed of, 93 . grass, 105, 106, I 50.

for lawn, 152,153 .

Cenchrus carolinianus, I65. echinatus, 165. pauciflorus, I65.

Census, report of 13 th, on grass crop, 4.

Chaetochloa geniculata; 165. glauca, 165 .
Chaetochloa italica, I2I.

lutescens, 165 . viridis, 165.

Cheat, I33, I64.

Chess, I33, I34, I64.

Chloris Gayana, III.

Clover, Japan, I3, 20. red, I3.

statistics of, 6,8 . white, $\mathrm{r}_{3}$.

Cock's-foot, 83 .

Cord'grass, I 47 .

Corn Belt, 24. chicken, I28, I29. cut for forage, 9 . for fodder, 24, 25 . Indian, I37.

Cortaderia argentea, I 54 .

Cotton Belt, I3.

Couch grass, I59; [Bermuda], 75.

Cowpea, 9, 13 .

Crabgrass, I62, 163 . weed in lawn, 65 .

Crested dog's tail, I 17 .

Crex, 157.

Crop areas, forage, I2.

Curly mesquite, I37, I38, I39.

Cynodon Dactylon, 76.

Cynosurus cristatus, Ir 7 .

Cyperus rotundus, $16 \mathrm{I}$.

Dactylis glomerata, 83 .

Darnel, 98.

Deserts, forage plants of, I42, 143.

Devil grass, 75 .

Distichlis spicata, I42.

Dog-town grass, 166.

Dry farming, I4.

Durra, I28, 129.

Echinochloa crusgalli, I25, I66. edulis, 125.

Eleusine indica, I66.

Epicampes macroura, I57.

Eragrostis cilianensis, I66.

Eriochloa subglabra, I I 8 .

Esparto, I 57.

Euchlaena mexicana, I32. 
Eulalia japonica, 154 .

Fescue grasses, I09. hard, I Io.

meadow, 83 . description of, 84 . mountain, $\mathrm{I} 45$. sheep's, I Io. slender, I Io. various-leaved, IIr.

Festuca arizonica, I45. capillata, i Io. duriuscula, II I. elatior, 85 .

heterophylla, III. idahoensis, 145 .

ovina, I Io. capillata, I Io. duriuscula, III. pratensis, 85 . var. elatior, 85 . rubra, III. heterophylla, I I I. viridula, 145 .

Feterita,' I28.

Fiber grasses, 157.

Flat-stem, I02.

Fodder, 24.

Forage crop areas, I2.

grasses, $\mathbf{I 0}$. annual, II9. native, 135 .

plants, classification of, $\mathbf{x}$. statistics of, $4,5,6,7$.

Fountain grass, 155 .

Fowl meadow grass, II6.

Foxtail [barley grass], I64. grass, I 22.

green, 122, I65.

meadow, II 7 .

yellow, 122, 165 .

Gardener's garters, I 54 .

Germinators, how made, $4 \mathrm{I}$.

Glumes, 49.

Golf courses, grasses for, 92.

Goose grass, 166.

Grains, small, I33.

Grama grass, I37, 138, I39. black, 139.
Grama grass, blue, I39.

Gramineae, IO.

Grass, Bahama, 75.

barley, as weed, 164 .

barnyard, I25, 166.

beach, 156 .

bent, 92 .

for lawn, I 52, 153 .

seed of, 93 .

Bermuda, I9, 20, 70, 74 .

as weed, I 59.

for lawn, . I 52 , I 53 . .

billion-dollar, 125 .

black, I 47 .

brome, I4, 2I, 89, 90.

annual, as weed, I44, 164 .

Australian, I07.

description of, 9I.

Hungarian, 9I.

Schrader's, I07. seed, 40.

buffalo, 136, 137, 138 .

bunch, I 4 I, 135 .

mountain, I 45 .

bur, 165 .

canary, reed, 147 .

Carib, I 18.

carpet, 105, 106, I 50.

for lawn, I52, I 53 .

cord, I 47.

couch, I59, [Bermuda], 75.

crab, 162, 163.

weed in lawn, 65 .

crested dog's tail, I I 7 .

crop, statistics of, 4 .

value of, 4 .

devil, 75 .

dog-town, I66.

family, Io, 28 .

fescue, I09.

flower, description of, 48 .

fountain, I 55 .

fowl meadow, I 6 .

foxtail, 122.

green, 122.

yellow, 122 .

goose, 166.

grama, I37, 138, I39.

black, I39.

blue, 139 . 
Grass, guinea, ro7.

Herd's 28, (red top), 77, 79 . how distinguished from other plants I I, 44.

Hungarian, 122. statistics of, 6,8 .

in rotation, 36 .

Indian, I4I. couch, 76 .

injurious, 167 .

Johnson, 9, I3 $, 85,88,89$. description of, 87 . eradication, 86. weed as, I 59 .

June, I9.

leaf, description of, 47 .

marram, $\mathrm{x} 56$.

meadow soft, I04.

names, Latin, significance of and why used, 28.

Napier, I I8, I49.

Natal, II2, I I3.

native, cultivation of, 147 .

nomenclature of, 27 .

nut, r6r.

oat, bulbous, 99 .

tall, 99, roo.

orchard, $9,80,82$.

description of, $8 \mathrm{I}$.

seed, 40, 8I.

pampas, I54.

Para, I07, 109.

pigeon, $\mathbf{I} 22$.

pine, I 45 .

plume, I 54.

quack, I 59, I6o.

eradication of, $\mathbf{I} 60$.

Randall, Ioo.

ray, 98 .

recently introduced, $\mathbf{I} 49$.

rescue, $107,108$.

Rhodes, III, II2.

ribbon, I 54 .

rough-stalked meadow, I 6 .

rye, 95 .

Australian 98.

description of, 97 .

English, 95, 96, 97, 98.

Italian, 95, 96, 97, 98 .

sacred, 75 .
Grass, St. Augustine, I04, I 50. for lawn, I52, I 53 .

St. Lucie, 73.

salt, I42. statistics of, 6,8 .

scutch, 75 .

seed, 37,40 .

description of, 50 .

determining purity of, 38 . sowing, 32 .

short, 137.

squirrel-tail, I64, I65.

stink, r66.

structure of, 44 .

Sudan, 14, I28, I29, I30.

sugar producing, I 57.

sweet vernal, I02.

switch, I4I.

tall oat, 99, roo.

tickle, I66.

Tunis, I28, I3I.

velvet, I03, I04.

wheat, slender, II3, I48, I49. western I46.

wild, statistics of, 6,8 .

wire [Bermuda], 75; [Canada bluegrass], I02; [Juncus balticus], I40.

Grazing industry, I35.

Guinea grass, 107.

Gynerium argenteum, I55.

Hay, coarse, 24.

fresh water marsh, 22.

grain, $15,23,133$. statistics of, 6,8 .

legume, 23.

making, 34 .

marsh, I 47 .

prairie, 22.

salt marsh, 23.

statistics of, $4,5,6,7$.

wild, 22,146 .

wild oats as, I33.

Herd's grass, 28 [redtop] 77, 79.

Hierba de Don Carlos, 89.

del prado, 75 .

fina, 75 .

Holcus halepensis, 89.

lanatus, I04. 
Holcus, Sorghum, I29.

Drummondii, 129. exiguus, I3I. sudanensis, I3I.

Hordeum, I64.

Gussoneanum, I64.

jubatum, I64.

murinum, I64.

nodosum, 165 .

pusillum, 165 .

Humid Region, cool, I2. warm, I3.

Hungarian brome grass, 9I. grass, 122. statistics of, 6,8 .

Indian couch grass, 76 . grass, I4r.

Japan clover, I3.

Johnson grass, 9, I3, 85, 88, 89 . description of, 87 . eradication of, 86 . weed, as, 159 .

Juncus Gerardi, 147.

June grass, I9.

Kafir, I4, I28, I29.

Lawn, Bermuda for, 72 . bluegrass, making, 6I. carpet grass for, I05. grass for, 92, I 5 I. grass mixtures, 152 . preparation of, 92.

St. Augustine grass for, 105. weeds, 65 .

Legumes, II.

Leguminosae, Io.

Lemmas, 49.

Linnaeus, 2.9.

Lolium italicum, 98. multiflorum, 98. perenne, 98 . var. italicum, 98. var. multiflorum, 98.

Lygeum Spartum, 157.

Maize, 132.

Manienie, 76 .
Marram grass, 156.

Meadow fescue, 83 . description of, 84 . seed, 40.

hay, 26.

plants, I6. soft grass, I04.

Meadows, 22. care of, 34 . mountain, forage grasses of, I 45 .

Meskit tree, I36.

Mesquite, I04.

Millet, 9, I4, 25.

Aino, 120.

broom corn, II9, I23, I24.

Chinese, Irg.

common, II9, I2O, I24.

German, I20, I2I.

Golden Wonder, 120.

hog, I24.

Hungarian, I20, 122.

Japanese barnyard, II9, I24, 125.

Kursk, I20.

pearl I I9, I26.

proso, II9, I22, I23, I24.

Siberian, 120 .

statistics of, 6,8 .

Turkish, I20.

varieties of, 120 .

Milo, I4, I28, 129.

Miscanthus sinensis, I54.

Napier, I I8, I 49.

Natal, II2, Ir3.

Notholcus lanatus, I04.

Nut grass, I6I.

Oat grass, bulbous, 99 . tall, 99, 100.

wild, as hay, I33, I66.

Orchard grass, $9,80,82$. description of, $8 \mathrm{r}$. "seed, 40, 8I.

Ornamental grasses, I53.

Palea, 49.

Pampas grass, I 54.

Panicum barbinode, I09. 
Panicum capillare, $\mathbf{I 6 6 .}$

Dactylon, 76.

dichotomiflorum, 166.

frumentaceum, I25.

italicum, I2I.

maximum, I07.

miliaceum, I24.

molle, I09.

smooth, I66.

virgatum, I4I.

Paper-making, grasses for, 157.

Para grass, 107, 109.

Paspalum compressum, 107. dilatatum, I14, I 5 .

Pasture, I6.

Bermuda grass for, $7 \mathrm{I}$.

care of, 32 .

carpet grass for, I05.

permanent, I8, 32 .

plants, I6.

Pato de gallina, 75 .

Penicillaria spicata, I 26.

Pennisetum americanum, I26. glaucum, I26.

purpureum, II 8.

Ruppelii, I55.

typhoideum, I26.

Phalaris arundinacea, I47. var. picta, 154 .

Phleum alpinum, 58, 145 .

pratense, 58.

Phyllostachys, I 55 .

Pigeon grass, I22.

Pine grass, 145 .

Plains, Great, grazing on, 122, I36.

Plume grass, I 54 .

Poa arachnifera, i 16. compressa, IOI. nevadensis, 142 . palustris, II 7 . pratensis, 70 . Sandbergii, I 44 . scabrella, 144 . serotina, I 7 . triflora; I I 7 . trivialis, I 16.

Proso, 122, I23, 124.

Prosopis juliflora, I36.
Quack grass, I59, I60: eradication of, I6o.

Randall grass, Ioo.

Range, depleted, rejuvenation of, I 49 .

Ray grass, 98.

Redtop 9, I3, 77, 78 . description of, 79 .

Natal, II2. seed 40,78 .

Reed canary grass, 147 .

Reed, giant, I 55 .

Rescue grass, 107, 108.

Rhizomes, 45.

Rhode Island bent, 92, 93, 94 . seed of, 93 .

Rhodes grass, III, II 2.

Ribbon grass, 154 .

Roots, 45.

Rootstocks, 45 .

Rotation, grass in, 36 .

Rough stalked meadow grass, II6.

Rye grass, 95 .

Australian, 98. description of, 97 .

English, 95, 96, 97, 98. Italian, 95, 96, 98 . wild, 167 .

Sacaton, I42.

Saccharum officinarum, 158.

Sacred grass, 75 .

Sage bush, I44.

St. Augustine grass, 104, 150. for lawn, I 52, I 53

St. Lucie grass, 73 .

Salt grass, 6, 8.

Sandbinding grasses, I56.

Sandbur, 165 .

Schrader's brome grass, 107. seed, grass, 37,40 . to determine purity of, 38 .

Scutch grass, 75 .

Seed testing, 4I.

Semiarid region, I3.

Setaria italica, I 21 .

Silage, 27. plants, 16. 
Sitanion, 167.

Soil, preparation of for meadow, 30.

Soiling, 26. plants, 16.

Sorghastrum nutans, I4I.

Sorghum I4, I26, I28, I29, I 57, I 58.

amber, 127 .

cut for forage, $\dot{9}$.

durra, 128 , 129.

halepense, 89 .

Kafir, I4, I28, 129.

milo, 14, I28, 129 .

non-saccharine, I 28.

orange, 127.

saccharine, 127 .

sugar, 127.

Sorghums, I26.

key to varieties of, $\mathbf{I} 27$.

Sorgo, I4, 127.

Sowing grass seed, $3 \mathbf{I}$.

Spartina patens, I47.

Spikelet, structure of, 48, 49 .

Sporobolus airoides, I4I.

Wrightii, I4I.

Squirrel-tail, I64, I65.

Stenotaphrum secundatum, I05.

Stink grass, I66.

Stipa tenacissima, 157 .

Stolons, 46.

Sudan grass, I4, I28, I29, I30.

Sugar cane, I $57,158$.

Sugar-producing grasses, I 57 .

Sweet vernal grass, 102.

Switch grass, I4I.

Syntherisma ischaemum, I62, I63
Syntherisma sanguinalis, 162.

Teosinte, I3I, I32.

Tickle grass, 166.

Timothy, 53.

and clover mixed, statistics of, 6,7 .

as meadow grass, 55 .

description of, 57 .

mountain, I 45 .

region, 13 .

seed, 40,57 .

standard hay of market, 26 .

statistics of, 6,7 .

Tricholaena rosea, II 3 .

Tunis grass, I28, I3I.

Velvet bent, 93,95 .

grass, 103,104 .

Water grass, I I4. paspalum, I I 4.

Weeds, annual, 162.

Weeds, grasses as, I 59 .

Wheat, Alaska, 2.

Egyptian, 2.

grass, slender, II3, I48, 149. western, 146.

mummy, 2.

Winter rains, region of, 15 .

Wire grass [Bermuda], 75; [Canada bluegrass], I02; [Juncus balticus], I40.

Yorkshire fog, I04.

Zea mays, $\mathrm{r} 32$. 
AUG $-1 \quad 1414$ 





\section{LIBRARY OF CONGRESS \\ |||||||||||||||||||||||||||||||||||||||||||

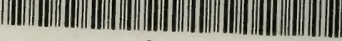 \\ 口002766023A}

